\title{
William Herle and the English Secret Service
}

\author{
Michael Patrick Gill
}

A thesis submitted in fulfilment of the requirements for the degree of Master of Arts at Victoria University of Wellington 
Table of Contents

$\begin{array}{lll}\text { Abstract } & \text { iii }\end{array}$

Abbreviations

Transcription Policy and Note on Dates $\quad$ v

Acknowledgements

$\begin{array}{ll}\text { Introduction } & 1\end{array}$

Chapter I: Herle's Early Life $\quad 12$

Chapter II: The Ridolfi Plot $\quad 40$

Chapter III: Contrasts in Patronage $\quad 65$

Chapter IV: Herle in the Netherlands $\quad 97$

Chapter V: the End of Herle's Career 112

$\begin{array}{lr}\text { Conclusion } & 139\end{array}$

$\begin{array}{ll}\text { Bibliography } & 145\end{array}$ 


\section{Abstract}

This thesis examines William Herle's life through his surviving letters to William Cecil, Lord Burghley, and other Elizabethan Privy Councillors. It emphasises the centrality of the Elizabethan patronage system to Herle's life, describing how his ties to Cecil helped Herle escape prison, avoid his creditors, and gain recompense for his service to Elizabeth. In exchange for Cecil's protection, Herle became deeply involved in Elizabethan intelligence networks, both domestic and foreign, throughout the 1570s and 1580s. Herle helped uncover plots against Elizabeth, passed vital information about events in the Spanish Netherlands back to England, and provided analyses of English foreign policy for his superiors. Despite his vital role, Herle never experienced true success, and died deeply in debt and abandoned by his patrons. Herle's life allows us wider insights into Elizabethan government and society. His experiences emphasises the inefficient nature of the Tudor foreign service, which utilised untrained diplomats who gained their position through political connections and were left to pay their own way through taking out loans they had little hope of repaying. Similarly, the numerous law suits which Herle describes in his letters are absent from official records, implying that Tudor society was even more litigious than previously assumed. Herle's life-long status as a gentleman, despite being arrested as a pirate and frequently imprisoned for debt, reinforces the lack of social mobility in Elizabethan England. His focus throughout his life on the need to support the 'Protestant Cause,' and his fear of an international Catholic conspiracy was shared by Cecil, Leicester, and Walsingham, and shows how deeply religious divisions affected English foreign and domestic policy. 


\section{Abbreviations}

BL British Library, London

HCA High Court of the Admiralty

HMC Historical Manuscripts Commission

MS Manuscript

ODNB Oxford Dictionary of National Biography, Oxford, 2004, Online Edition, 2008

SP State Papers

STC Short Title Catalogue

TNA National Archives, London 


\section{Transcription Policy and Note on Dates}

In transcribing Herle's letters every effort has been made to keep them as close to the original as possible. Original spelling has been used throughout, with abbreviations expanded in square brackets. Monetary figures have been provided in pounds when possible, and converted from roman numerals to modern Arabic style. Dates are in Old Style throughout. 


\section{Acknowledgements}

Thanks must first go to my supervisor Glyn Parry for his invaluable advice and guidance, without which this thesis would not have been completed. Thanks also to my fellow postgraduate students Lanei Alexander, James Campbell, Malcolm Craig, Michael Devine, and Nick Radburn for providing commentary on my many drafts. I am also grateful to Jean Anderson for her translation of the Duchess of Parma's letter, and the History Department for providing a comfortable and accommodating working environment. Special thanks go to my family, friends, and Fiona for their encouragement and support throughout my MA. 


\section{Introduction}

William Herle is a fascinating historical figure whose unfortunate lack of success during his own lifetime is equalled only by the paucity of attention historians have paid him since his death. Born into sixteenth-century Welsh gentry, Herle spent the vast majority of his life in government employ. Heavily involved in the English diplomatic scene, over time he moved from a promising young loans negotiator, to an ambassador to the Dutch province of East Friesland. Yet this respectable career arc was only half of Herle's life. While serving abroad he monitored local events, sending back intelligence reports to his superiors in England that helped shape foreign policy at the highest level. Furthermore, Herle played a vital role in uncovering two insidious conspiracies against the English crown, the Ridolfi and Throckmorton plots. When combined with accusations of piracy, a tendency to run up massive debts, and multiple stints in prison, however, it becomes clear that this second aspect of Herle's life had a decidedly seedy undertone. The ignoble aspects of Herle's career, combined with his inability to gain a title or substantial honours, have led previous historians to overlook his life.

Part of the twentieth century historians' move away from meta-narratives to micro- and local history has been an increased focus on studies of small communities and lesser known figures. The genre of biography, however, has largely avoided this movement. Tudor historians have focused almost exclusively on the most powerful and influential figures of the age. Monarchs, Privy Councillors, bishops, and nobles - the only low ranking figures deemed to rate in-depth study are literary luminaries such as Shakespeare and Marlowe. A large part of the reason for this imbalance is the lack of sources detailing the lives of ordinary people. Even with Shakespeare, where historians and enthusiastic amateurs have combed every archive imaginable, large gaps still exist. 
Over the four hundred intervening years, most documents relating to people's lives have been lost. It is only those that remained in government archives or private collections that survived the passage of time, and the vast majority of these documents were written by, or to, those with wealth and power. As a figure who existed on the penumbra of Elizabeth I's glittering court, Herle is a prime candidate for the sort of thorough study that has previously been denied him. He is one of the few people from his era and caste about whom a significant number of documents survive.

While exact details of Herle's birth and death are missing, over three hundred of his letters survive in archives across Britain. The vast majority of these were written to William Cecil, Elizabeth's Secretary of State, and are stored in the National Archives, the British Library, and Hatfield House. Although Herle's letters were written to those of a higher rank than him, they provide valuable insights into the life and times of an Elizabethan gentleman. Out of necessity most historical narratives of high level politics in this period are constructed from the official correspondence, minutes and letters of Cecil, his successors as Secretary, and his subordinates. This thesis will follow that trend, although as the overwhelming majority of these primary sources were written by Herle himself it provides a far more personal account than most previous analyses of this era.

\section{Herle Historiography}

William Herle has been largely overlooked by historians. Often mentioned in passing but rarely described in detail, Herle is almost exclusively associated with his role in the Ridolfi Plot. Conyers Read, in his biography of Cecil, depicted Herle in a distinctly negative light, describing him as 'a cunning fellow' who 'managed to worm his way' into conspirators' confidences before delivering them up for torture. ${ }^{1}$ John Bossy retained Read's description, but admitted that the latter's judgement of Herle was

\footnotetext{
${ }^{1}$ Conyers Read, Lord Burghley and Queen Elizabeth, New York (N.Y.), 1960, p.39.
} 
somewhat harsh. ${ }^{2}$ Stephen Alford's description of Herle as an 'expert intelligencer and informant' is both kinder and more accurate than Read's. ${ }^{3}$ Yet like Read and Bossy, Alford ignores Herle outside of his role in the Ridolfi plot, giving a distorted view of his role in the Tudor world.

In 1971 David Lewis Jones wrote the first article addressing Herle outside the context of the Ridolfi plot. 'William Herle and the Office of Rhaglaw in Elizabethan Cardiganshire' focused on Herle's time as an official in East Wales during the late 1570 s, and included a brief biography of Herle's life up until that point. ${ }^{4}$ Despite its title Jones' article proved to be less about Herle than it was the many ways Cardiganshire locals exploited the English legal system to avoid paying taxes. Jones retained Read's harsh judgement of Herle, describing him as undertaking a 'devious career' in which he used the influence of his friends to avoid imprisonment for piracy and benefited from 'the odious position of prison spy. ${ }^{5}$ Jones also composed Herle's Oxford Dictionary of National Biography entry, providing a relatively accurate picture of Herle's career, albeit one with a distinctly pessimistic overtone. His final word on Herle was that his superiors 'considered him useful but not entirely trustworthy,' a sure sign that his impression of Herle was very much based on the darker side of Herle's career. ${ }^{6}$

In 2004 Robyn Adams submitted her $\mathrm{PhD}$ dissertation 'Both Diligent and Secret: The Intelligence Letters of William Herle,' doubling the historical analysis of Herle at a stroke. ${ }^{7}$ Adams was the first historian to look at a significant number of Herle's letters, and her thesis focused on their 'epistolary and social minutiae,' providing an in depth analysis of his writing style. This study was a valuable

\footnotetext{
${ }^{2}$ John Bossy, Giordano Bruno and the Embassy Affair, New Haven (Conn.), 1991, p.26.

${ }^{3}$ Stephen Alford, Burghley: William Cecil at the Court of Elizabeth I, New Haven (Conn.), 2008, p.169.

${ }^{4}$ David Lewis Jones, 'William Herle and the Office of Rhaglaw in Elizabethan Cardiganshire,' National Library of Wales Journal, vol.17, 1971-72, pp.161-179.

${ }^{5}$ Ibid., p.161.

${ }^{6}$ David Lewis Jones 'William Herle (d. 1588/9)', ODNB, http://www.oxforddnb.com/view/article/37536, accessed 11 May 2010.

7 Robyn Adams, "'Both Diligent and Secret": The Intelligence Letters of William Herle,' PhD Dissertation, University of London, 2004.
} 
contribution to the small amount of scholarship on Herle, yet Adams' focus on the linguistic aspects of Herle's letters led her to ignore or gloss over much of their historical context.

Since submitting her dissertation, Adams has published three further articles on aspects of William Herle's life, all in 2009. The first detailed Herle's stint in the Marshalsea during the Ridolfi plot, comparing his use of epistolary formulae and codes to the norm of sixteenth century letters, and utilising Herle's descriptions to analyse prison conditions. ${ }^{8}$ Her second article compares the four surviving copies of Herle's report to Cecil on the Netherlands in various archives, noting the differing scribal and archival practices that each shows, and extrapolating from this the provenance of each document. ${ }^{9}$ Throughout all of these publications, Adams' primary focus is on epistolary rather than historical analysis, and this thesis argues that it is the latter which Herle now requires. Adams' most recent publication has begun to fill this void somewhat. In it she demonstrates how Herle fitted into Patrick Collinson's model of Elizabethan "citizens," men in government service who saw it as their duty to provide counsel to their Privy Councillor superiors. ${ }^{10}$

While Adams has begun to move in the right direction with her most recent publication, there remains a distinct gap in the historical literature on Herle. Adams' work has provided ample coverage of the epistolary importance of Herle's letters. What remains unstudied, and what this thesis will address, is an overview of Herle's life, how he fitted into the Elizabethan world, and what the overarching themes of his life can tell us about him and his contemporaries. By studying Herle's life through his letters, we

\footnotetext{
${ }^{8}$ Robyn Adams, 'The Service I am Here for: William Herle in the Marshalsea Prison, 1571,' The Huntington Library Quarterly, Vol.72, No.2, 2009, pp.217-238.

${ }^{9}$ Robyn Adams, 'Signs of Intelligence: William Herle's Report of the Dutch Situation, 1573,' Lives and Letters, Vol.1, No.1, Spring 2009, pp.1-18.

${ }^{10}$ Robyn Adams, 'A Spy on the Payroll?: William Herle and the Mid Elizabethan Polity,' Historical Research, Vol.83, Issue 220, 2010, pp.1-15; Collinson's model can be found in: Patrick Collinson, 'Servants and Citizens: Robert Beale and Other Elizabethans,' Historical Research, Vol.79, Issue 206, 2006, pp.496-497.
} 
can gain insight into a multitude of aspects of Tudor politics, economics, and society. In order to place Herle in the wider context of the Elizabethan world, the people he corresponded with and the events he was a part of must be discussed. Almost without exception these external agencies which informed Herle's life can be divided into either the field of foreign policy, or that of intelligence gathering. Both these fields have received substantial attention from academics.

Studies of foreign policy have been a popular topic for historians throughout the ages. R.B. Wernham's Before the Armada has provided an excellent overview of the main shifts in Tudor foreign policy for almost fifty years. ${ }^{11}$ Wernham's focus on the overall picture often led him to obscure the specific details of each incident he covered, and his reliance on the nineteenth century calendars over manuscript originals left him at the mercy of Victorian tastes and prejudices. ${ }^{12}$ Wallace T. MacCaffrey's three volume history of Elizabethan policy provides a far more detailed study than Wernham's overview and benefits from being published over twenty years, allowing MacCaffrey to incorporate a range of other scholars' research that was published in the interim. ${ }^{13}$ Conyers Read's biographies of Cecil and Sir Francis Walsingham detail the traditional views on Elizabethan Privy Councillors; however, his interpretations have come under attack by subsequent scholars. Stephen Alford's work on Cecil and Simon Adams' on Leicester, have forced a re-examination of many of the assumptions made about each man's position on various aspects of foreign policy, and overturned the long held image of a court divided into factions. ${ }^{14}$

Cecil and Walsingham's domination of intelligence gathering and analysis in the Elizabethan era have led their biographers to dominate these fields of historical inquiry

\footnotetext{
${ }^{11}$ R.B. Wernham, Before the Armada: The Growth of English Foreign Policy, 1485-1588, London, 1966.

12 See the incidence of calendar reference in Wernham's notes; Ibid., pp.409-426.

${ }^{13}$ Wallace T. MacCaffrey, The Shaping of the Elizabethan Regime, Princeton (N.J.), 1968; Wallace T. MacCaffrey, Queen Elizabeth and the Making of Policy, 1572-1588, Princeton (N.J.), 1981; Wallace T. MacCaffrey, Elizabeth I: War and Politics, 1588-1603, Princeton (N.J.),1992.

${ }^{14}$ Simon Adams, Leicester and the Court: Essays on Elizabethan Politics, Manchester, 2002; Alford.
} 
as well. The vast majority of authors in this area have relied heavily on a combination of paraphrasing Read's manuscript analysis and repeating earlier historians' conclusions, rather than analysing primary sources themselves. The worst example of this is Alan Haynes' The Elizabethan Secret Services, which was lambasted by critics as raising 'as many questions about the historian's craft as it does about quality control standards of the publishing industry. ${ }^{15}$ Amongst a torrent of cutting reviews, the kindest comment was that of David Loades who said that Haynes' book 'is not an important historical study, but it is a good read. ${ }^{16}$

Haynes' work is not the only poor attempt at history of Elizabethan intelligence gathering. Francis Edwards, for example, has published a number of works analysing Elizabethan and Jacobean plots perpetrated by Catholics. Each follows the same line, detailing the English government's Machiavellian attempts to entrap Catholics by manufacturing plots against the Queen. Pauline Croft has accurately noted Edwards' tendency to ignore the majority of modern scholarship which does not support his interpretation, and his tendency to twist facts until they conform to his argument. ${ }^{17}$

Poor historical studies are not limited to historians. English literature professor Curtis Breight has similar views about Cecil as Edwards, arguing that the Elizabethan government instituted a 'State of Terror.' ${ }^{18}$ Breight's historical analysis is severely lacking, due to his reliance on secondary sources such as Read and Edwards. ${ }^{19}$ Perhaps most telling is his statement that he has preferred the Calendar of State Papers to the State Papers themselves, dismissing manuscript sources as too time consuming to study,

\footnotetext{
${ }^{15}$ Ronald Pollit, 'Review of Invisible Power,' Albion: A Quarterly Journal Concerned with British Studies, Vol.25, No.3, Autumn 1993, p.487.

${ }^{16}$ David Loades, 'Review of Invisible Power,' The English Historical Review, Vol.110, No.437, June 1995, p.731.

${ }^{17}$ Pauline Croft, 'Review of Plots and Plotters in the Reign of Elizabeth I,' The Catholic Historical Review, Vol.90, No.2, April 2004, p.321.

${ }^{18}$ Curtis C. Breight, Surveillance, Militarism, and Drama in the Elizabethan Era, New York (N.Y.), 1996, p.34.

19 Ibid.
} 
and arguing that they would merely corroborate his thesis in any event. ${ }^{20}$ Breight's book is, in his own words, 'neither historiography nor literary criticism' but a hybrid of the two. ${ }^{21}$ Unfortunately, he has failed to mesh them together adequately, with critics taking as dim a view of his literary criticism as this thesis does of his historical methods. ${ }^{22}$

While academic studies of the Elizabethan intelligence network are largely nonexistent, works written for a popular audience are far more common. Alison Plowden's The Elizabethan Secret Service is a good introduction to the various conspiracies of the Elizabethan period. Plowden provides a well written, easy to follow narrative that avoids the worst abuses of other authors. ${ }^{23}$ Her opinion of Herle is less than complimentary, describing him as drawn by Cecil from 'the upper ranks of [the] criminal underclass,' a statement clearly informed by Read's dismissal of Herle rather than his true status as a gentleman. ${ }^{24}$ Plowden's use of Mary, Queen of Scots, as the driving force of her narrative is mirrored by Stephen Budiansky's focus on Sir Francis Walsingham in Her Majesty's Spymaster. ${ }^{25}$ Despite its title, Budiansky's work is less a biography than it is a general study of Elizabethan intelligence practices focusing on those under Walsingham. Much like Plowden, Budiansky has produced a readable but largely un-cited book that is good in general details but makes a number of mistakes in its particulars. ${ }^{26}$

\footnotetext{
${ }^{20}$ Ibid., p.34.

${ }^{21}$ Ibid., p.38

${ }^{22}$ See for example: Michael G. Brennan, 'Review of Surveillance, Militarism, and Drama in Elizabethan England,' The English Historical Review, Vol.113, No.452, June 1998, pp.726-727; and Richard Burt, 'Review of Surveillance, Militarism, and Drama in Elizabethan England,' Shakespeare Quarterly, Vol.49, No.4, Winter 1998, pp.464-466. Both reviewers question Breight's faulty logic, narrow range of literary sources, and lack of 'conceptual subtlety.' Burt also attacks Breight for spending too much time on historical background and playing 'the 'I'm more historical than thou" archive game.' The fact that Breight's archival work is almost non-existent seems to have escaped Burt.

${ }^{23}$ Alison Plowden, The Elizabethan Secret Service, New York (N.Y.), 1991.

${ }^{24}$ Ibid., p.26.

${ }^{25}$ Stephen Budiansky, Her Majesty's Spymaster: Elizabeth I, Sir Francis Walsingham, and the Birth of Modern Espionage, London, 2005.

${ }^{26}$ For a discussion of some of these mistakes see: Paul Hammer, 'Review of Her Majesty's Spymaster,'

The Journal of Military History, Vol.71, No.1, January 2007, pp.216-217.
} 
John Bossy's two books in this area are undoubtedly the best published works on Elizabethan intelligence. Giordano Bruno and the Embassy Affair and Under the Molehill both deal with events surrounding the Throckmorton plot, are thoroughly researched, well written, and include extensive sourcing. ${ }^{27}$ Furthermore, Bossy is the only published author that details this series of events who acknowledges Herle's involvement. He paints a less harsh picture of Herle than most historians, probably due to his focus on an incident that occurred during Herle's later career, describing him as 'nearly respectable. ${ }^{28}$ His reliance on Read's portrayal of Herle, however, leads Bossy to perpetuate Read's errors. ${ }^{29}$

The corpus of historical work undertaken on William Herle is thin indeed. Only two historians have published works directly related to Herle, and Adams' $\mathrm{PhD}$ dissertation remains the only attempt to address more than one aspect of his life in a single publication. The two areas which this thesis argues are most significant in Herle's life, Elizabethan foreign policy and intelligence gathering, are better served but remain largely the providence of non-academic works or general histories. Half a century after his biographies were published, Conyers Read remains the most influential author in the field. His negative portrayal of Herle has contributed greatly to historians' tendency to sideline Herle, and focus exclusively on his role in the Ridolfi plot. While this thesis argues that this was an important aspect of Herle's life, it was certainly not the only one worth investigating. A study of Herle's life, and an analysis of what it shows us about aspects of early modern England, is long since due. What Robyn Adams has done for the style of Herle's letters since 2005, this thesis aims to do for their content.

\footnotetext{
27 Bossy, Giordano Bruno; John Bossy, Under the Molehill: An Elizabethan Spy Story, New Haven (Conn.), 2001.

${ }_{28}^{8}$ Bossy, Giordano Bruno, p.26.

${ }^{29}$ Ibid. The most glaring error is his statement that Herle began his career in the public service in 1571 (missing his reports from the 1560s). See footnote 21 in Giordano Bruno for Bossy's references to Read, showing where he picked up this erroneous idea.
} 


\section{Thesis Structure}

This thesis is part biography of Herle, part wider study of themes connected to his life, and each of these halves will be addressed throughout. Its biographical nature is somewhat problematic in that analysing any person from the early modern period raises certain concerns about the ability of historians to document their lives accurately. The large number of Herle's letters that survive ameliorates this problem somewhat, although many of the other documents one would wish for are still absent from archives.

Furthermore, when extrapolating themes from Herle's life to a wider context it is necessary to ask exactly how representative of his contemporaries Herle was. Although Herle was neither a member of the nobility, nor a truly exceptional person such as Cecil or Walsingham, his varied career makes it unlikely that there were any other people whose circumstances matched his. The list of those whose careers touched on an aspect of Herle's, however, is significantly larger. When the diplomats, intelligencers, sheriffs, negotiators, tax-collectors, and messengers of Elizabethan England are added together, they would comprise the majority of its civil service. If one adds the pirates, stoolpigeons, and imprisoned debtors, a significant portion of its criminals are included. In fact, this thesis would argue that the varied nature of Herle's career means that aspects of his life touch on the majority of the gentry, and a significant portion of other commoners.

While Herle did not serve a singular role in the Tudor world, the records we have of him are unique. Over three hundred of Herle's letters survive, a number unmatched by any other person of his social station. This degree of preservation is generally reserved for the correspondence of Privy Councillors, and the majority of Herle's superiors have left less to posterity than he has. It would seem odd, then, that this resource has been left untapped for so long. Although Read's dismissal of Herle as 
a degenerate criminal, and later historians' unquestioning acceptance of his assessment, has contributed greatly to Herle's omission, the main reason for this is the disparate locations of the sources. Spread across archives in London, Hertfordshire, Wiltshire, Oxford, and Edinburgh, and thus catalogued separately, studying Herle's letters required historians to travel the length of Britain. It is only with the advent of online initiatives such as the University of London's Centre for Editing Lives and Letters and the National Archives' State Papers Online that studying Herle's entire corpus of letters has become a realistic goal. Their transcripts and scanned manuscripts of Herle's letters are the primary resource utilised in this thesis.

This thesis is structured chronologically, as a linear progression of time allows the reader to see the natural evolution of Herle's career. Significant themes in Elizabethan policy and daily life are discussed when Herle first encounters them, allowing us to see how Herle adapted to changing circumstances. The exception to this linear structure is the third chapter, which details incidents throughout the 1570s and 1580s in order to show how Herle's patron-client relationship with Cecil evolved. The remaining four chapters each cover a portion of Herle's documented life.

The first chapter details what little we know of Herle's early life. Herle's move from an undocumented early career as a merchant in training to government service is informed by a discussion of the Tudor system of patronage which tied Herle to Cecil. We then follow Herle as his early promise was derailed by accusations of piracy. The chapter closes with Herle imprisoned for his crimes, abandoned in the Marshalsea while he pleaded with his patron to secure his release.

The second chapter covers Herle's reinvention of himself as an intelligencer. Its main focus is his involvement in the Ridolfi plot which brought him to the attention of those in power and secured him a place in Cecil's affinity as an information broker. This shift from financial to political concerns involved Herle in the government's 
increasing fears of an international Catholic conspiracy to destabilise the English throne. While Herle was rewarded for the work he undertook in the Ridolfi plot and its aftermath, his debts increased during this period and credit issues were foremost in his mind throughout it.

The third chapter details Herle's interaction with his patrons, showing how he leveraged his utility to Cecil into protection and rewards. The numerous examples of this across the 1570s are contrasted with those of the 1580s when Herle proved unable to exercise similar power, a fact which was largely due to his decreasing utility. Herle's disastrous argument with Cecil further contributed to his decline, as did his attempts to gain the support of other Privy Councillors.

The fourth chapter covers Herle's increasing focus on the Spanish Netherlands and the plight of the Dutch Protestants there. It shows how the English government utilised Herle's Netherlands connections to inform their decisions, and details the problems that the ad hoc nature of the Tudor foreign service caused. Herle's biases and beliefs influenced the tone and content of his reports greatly, and he did not always represent Elizabeth's interests. He tended to make updates based on poor information, which caused problems such as his premature reporting of William of Orange's death.

The final chapter details Herle's involvement in the Throckmorton plot's uncovering, and his return to the Netherlands as ambassador to East Friesland. The apex of Herle's diplomatic career, when he negotiated with the Count of Emden in East Friesland, is contrasted with his rapid decline immediately after this watershed event. The chapter closes with a discussion of his final collapse into financial ruin, sickness, and death. 


\section{Chapter I: Herle's Early Life}

William Herle was born into a world where connections to powerful people, information about the movements and probable actions of others, and access to the funds necessary to benefit from these considerations were vital to anyone hoping to forge a diplomatic or political career. This chapter will outline a number of interrelated concepts fundamental to understanding Herle's life and career: how the Tudor government worked; its dependence on patronage networks; and the major components of patronage, service and reward. It will then turn to Herle's early life, describing what little we know of his birth and the time before he entered government service. Herle's early career will also be outlined, his success in negotiating government loans in Antwerp and the rewards he received for doing so, followed by the collapse of this initial promise in the face of law suits, debt and accusations of piracy.

\section{Tudor Government and Patronage}

It is no exaggeration to say that the central figure in William Herle's life was Sir William Cecil, later Lord Burghley, Elizabeth I's Secretary of State and eventually Lord Treasurer. Herle's close ties to Cecil, as well as his later links to Robert Dudley, the Earl of Leicester, and Sir Francis Walsingham, are an illustration of the Tudor patronbased governmental system in action. Much has been written by historians on Tudor government: whether it existed, how extensive it was, what its major components were, and who really held the power within it.

Over the course of the twentieth century, there was a noticeable shift in historians' focus on the Tudor government. Read summed up the early twentieth century position well when he stated that 'a great deal has been made...of the factions which divided the Queen's Council...[and found] its most striking expression in the 
inveterate antagonism between Leicester and Burghley. ${ }^{1}$ Read and his contemporaries focused on the major personalities of the Elizabethan world: Cecil, Leicester, Walsingham, Sir Christopher Hatton, and the Queen herself. The interaction between these "great men of history" was the means by which the government operated. The rivalry and occasional antagonism between Leicester and Cecil was extrapolated into a schism between the moderate and extreme Protestants in the Privy Council.

By the 1970s a strong focus on parliamentary process and powers had come to the fore, with Geoffrey Elton confidently assuring the Royal Historical Society that 'as the sovereign maker of laws, Parliament thus stood ideologically central to the problem of political stability' in Tudor England. ${ }^{2}$ Over time these approaches have become more detailed and integrated, to the point where Penry Williams devoted an entire book to describing noblemen's affinities, and their interrelated nature. ${ }^{3}$ The largest and most prestigious affinity was that of the monarch, which David Loades has detailed in his extensive research into the court's structure. ${ }^{4}$

However, the court-centred system described by Williams and Loades only scratches the surface of the complex matrix of relationships that formed Elizabethan society. While Loades argues convincingly that 'England was governed from the court, because the monarch governed and the court was the monarch's immediate context,' other historians have pointed out that the idea of a "court" itself is more a "convenient conceptual piece of shorthand' for historians to describe those around the monarch than it was a genuine institution. ${ }^{5}$ Loades' "court" was essentially the informal centre of Tudor patronage - significant mainly for the monarch's ability to dispense wealth and

\footnotetext{
${ }^{1}$ Conyers Read, Mr Secretary Walsingham and the Policy of Queen Elizabeth: Vol. I, Oxford, 1925, p.viii.

${ }^{2}$ Geoffrey Elton, 'Tudor Government, The Points of Contact I, Parliament,' Transactions of the Royal Historical Society, Fifth Series, Vol.24, 1974, p.186.

${ }^{3}$ Penry Williams, The Tudor Regime, Oxford, 1979.

4 David Loades, The Tudor Court, Revised Edition, Bangor, 1992; David Loades, Power in Tudor England, New York (N.Y.), 1997.

${ }^{5}$ Loades, Power in Tudor England, p.133; Geoffrey Elton, 'Tudor Government: The Points of Contact III: The Court,' Transactions of the Royal Historical Society, Fifth Series, Vol.26 (1976), p.211.
} 
honours to petitioners rather than as the official seat of government. Herle himself went to Elizabeth's court a number of times, but rather than making his pleas to the Queen in person he usually relied on his affinity with Cecil.

Herle's position at court was largely due to Cecil's personal dominance of the political scene and his influence over the Queen. A large part of what we would now consider the civil service was, in the Elizabethan era, part of the monarch and her ministers' private households, a fact which was especially true in Cecil's case. There was no demarcation between Cecil's servants' domestic and official duties, and they often worked primarily on government business. ${ }^{6}$ His household was largely composed of those with familial or regional ties to him. ${ }^{7}$ Despite his close ties to Cecil, and his employment in roles usually reserved for councillors' servants, Herle does not seem to have been permanently attached to Cecil's household, and their relationship was clearly that of patron-client rather than master-servant.

The most significant power relationship in the Elizabethan period was the patron-client one, a reciprocal yet unequal bond in which 'patrons provide material benefits and protection, and clients in return provide loyalty and service. ${ }^{8}$ Whilst a client could expect his patron to strive for his advancement and intercede on his behalf with other powerful figures, in return the patron expected absolute dedication to his cause. Maintaining a network of reliable subordinates was particularly important in the cut-throat world of Tudor politics, and no powerful figure was likely to neglect this for long. Information was power, and Herle's role as information broker made him a crucial part of Cecil's affinity.

\footnotetext{
${ }^{6}$ Richard Barnett, Place, Profit, and Power: A Study of the Servants of William Cecil, Elizabethan Statesman, Chapel Hill, 1969, p.11.

${ }^{7}$ George Morrison, 'The Land, Family, and Domestic Following of William Cecil, Lord Burghley, c.1550-1598,' PhD Dissertation, Oxford University, 1990, pp.165-179.

${ }^{8}$ Sharon Kettering, Patrons, Brokers, and Clients in Seventeenth-Century France, New York (N.Y.), 1986, p.13.
} 
Excepting the Queen, William Cecil was the most powerful patron in Elizabethan England, and Herle benefited from his ties to the Secretary. Pauline Croft has convincingly argued that the Cecil and his son Robert dominated the Elizabethan cultural and political scene through their unrivalled patronage network. ${ }^{9}$ Cecil's key position in Elizabeth's government makes it difficult to separate his influence from that of the Crown, and it appears that contemporaries often saw the two as much the same thing. ${ }^{10}$ With the Queen as the ultimate patron, Cecil acted as a conduit for her benefice, advising her on patronage decisions, and even as a filter for royal clients, deciding who should speak to the Queen and who he could deal with himself. Writing to Cecil in late 1569, Herle described him as 'the true and undowted Patron of the whole Comune weall,' indicating the breadth of Cecil's pervasive influence. ${ }^{11}$

Cecil was undoubtedly Herle's primary patron, a relationship forged in the early years of Elizabeth's reign which continued until Herle's death nearly thirty years later. In 1572 Herle described Cecil as 'mi only Patron and refuge,' a situation which only seems to have changed in the early 1580 s when Walsingham and Leicester became his secondary patrons. ${ }^{12}$ Despite the influence of his other patrons, Herle always returned to Cecil. The vast majority of his surviving letters are addressed to Cecil, including almost every one of those that beg for financial assistance or request personal intervention with the monarch, the traditional roles of a patron.

This relationship seems at times to have been a close one, to the point where some historians have assumed Herle was related to Cecil. Read described Herle as 'a Welshman by birth' who 'later claimed descent from the same Welsh family as the

\footnotetext{
${ }^{9}$ Pauline Croft (ed.), Patronage, Culture, and Power: The Early Cecils, 1558-1612, New Haven (Conn.), 2002, pp. ix, xviii-xx.

${ }^{10}$ Julia Merritt, 'The Cecils and Westminster, 1558-1612: The Development of an Urban Power Base,' in Croft (ed.), Patronage, Culture, and Power, p. 233.

${ }^{11}$ Herle to Cecil, 22 December 1569, BL MS Lansdowne 12 f.36r.

12 Herle to Cecil, 14 May 1572, TNA SP 12/86/36, f.165r; Thomas Dannet to William Davison, 25 October 1586, TNA SP 12/194/60, ff.130r-131v; Herle's first surviving to Leicester dates from 1563 but it was not until 1580 that he began to write to him regularly. Similarly, Herle's letters to Walsingham begin in 1581 but are concentrated almost exclusively in 1582 .
} 
Cecils. ${ }^{13}$ Read was presumably basing this on one of Herle's begging letters to Cecil, where he described himself as 'a poore member of your lyne., ${ }^{14}$ Previous historians have failed to note a similar comment from 1587 in which Herle stated that he was bound to Cecil 'by the howse that I com of.' ${ }^{15}$ Both these statements, however, are decidedly ambiguous, and could merely be an indication of Herle and Cecil's common Welsh origins. Any evidence that can be cited for a familial connection between Herle and Cecil is purely circumstantial, and could equally be merely indicative of their close patron-client relationship.

In her $\mathrm{PhD}$ dissertation Robyn Adams made a strong case against Read's identification of Herle and Cecil as related, although mistakes in her evidence undermine her argument somewhat. Adams' case is based around the fact that Herle addressed other people clearly not related to him, such as Leicester, as 'good cosyn,' citing a 1581 letter from Herle to the Earl. ${ }^{16}$ However, the communication she refers to was addressed to Edmund Cornwall, Baron of Burford, rather than Dudley. ${ }^{17}$ Little is known about Cornwall, although it is possible that he was sheriff in Shropshire. Given Shropshire's proximity to Wales, there is a chance that he was related to Herle, but there is no proof either way. Herle's familial relationship with Cecil, or lack thereof, remains similarly obfuscated. There is no conclusive evidence to support Read's argument, and it is likely that Herle's kinship claim was based more upon a formulaic ratification of the parties' patronage relationship than to actual familial ties. The fact that in over three hundred letters, only two lines could be inferred to mean that the two were related strongly indicates that this was not the case. Herle was not the sort of man to pass up the opportunity to make the most of any connection to Cecil that he may have had.

\footnotetext{
${ }^{13}$ Read, Lord Burghley, p.39.

${ }^{14}$ Herle to Cecil, 19 October 1577, BL MS Lansdowne 25, f.129r.

${ }^{15}$ Herle to Cecil, 19 March 1587, BL MS Lansdowne 55, f.217v.

${ }^{16}$ Adams, 'Both Diligent and Secret,' p.74.

${ }^{17}$ Herle to Cornwall, 5 March 1580, TNA SP 12/148/13, ff.53r, 55v; Adams cites the same document, but notes the addressee as the Earl of Leicester: Adams, 'Both Diligent and Secret,' p.74.
} 
A patronage relationship had the distinction of being both public and private, and Herle's use of letters as his primary means of communication meant that these two aspects of patronage were often presented side by side. Herle often added personal touches to his letters containing otherwise political information. In late 1573, for example, he commiserated with Cecil on the harsh vagaries of sickness, describing himself as 'most humbly sorye, as it becomes me, for your L[ordship's] sicknes, \& as glad to here that the payne is mitigated. ${ }^{18}$ Herle well understood the pains of poor health, as he himself was frequently ill, a typical example of which was his sickness in 1575. The grievous nature of that illness was such that Herle apologised to Cecil for the 'raggednes of mi hand \& my tedyowsnes, which ye may ympute to mi sycknes. ${ }^{19}$ Over a decade later he informed Cecil that he had 'fallen sick againe, wasted with melancholie. ${ }^{, 20}$ In the same letter where he detailed such private information, Herle described the political situation in East Friesland, and enclosed letters from the Low Countries and France. This juxtaposition of politically sensitive and highly personal information is unexpected for the modern reader, but is perfectly reasonable given the role of the letter as the only real form of distant communication in the Elizabethan world.

Communicating primarily by letter made it difficult to convey degrees of meaning, particularly when Herle walked the fine line between appropriate concern for his patron and obsequiousness. Assuring Cecil that he was on the right side of this line, Herle claimed that 'mi pore mite of good will, is nott to make ani ostentacyon therof, butt to praye for yow \& serve yow durynge life, with all truste $\&$ affection. ${ }^{21}$ The affectionate aspect of a patronage relationship was not limited to letters from the client. Cecil returned Herle's trust and affection in kind, adding personal touches to his

\footnotetext{
${ }^{18}$ Herle to Cecil, 8 December 1573, BL MS Lansdowne 18, f.34r.

${ }^{19}$ Herle to Cecil, 11 March 1575, TNA SP 70/137/67, f.209v.

${ }^{20}$ Herle to Cecil, 17 August 1585, BL MS Lansdowne 46, f.36r.

${ }^{21}$ BL MS Lansdowne 18, f.34r.
} 
patronage such as a letter of reference, recommending Herle to 'ani wydow that he wolld make that superscription [of marriage] to. ${ }^{, 2}$ For a man who wrote so many letters to his social superiors, there is remarkably little evidence of Herle's early life remaining.

\section{Early Life and Education}

As is typical for the majority of Elizabethans outside the nobility, no records of William Herle's date or place of birth have survived. Nor does he appear in official documents, the main sources for Herle's later life, until the late 1550s. It is possible to suggest an approximate date of birth, however, from his first extant piece of official correspondence. ${ }^{23}$ As Herle was travelling on a diplomatic mission to Germany on behalf of William Cecil in early 1559, an important duty which would have only been given to an adult, we can posit Herle's date of birth as being somewhere in the 1530s. More exact dating is impossible with surviving data.

Herle described himself as 'a gentillman...of honest linaige,' a status he managed to maintain throughout his life, despite his often decidedly un-genteel actions. ${ }^{24}$ Cecil himself described Herle as 'verey well borne, \& of a good kinred,' referencing Herle's status as a member of the gentry. ${ }^{25}$ The gentry were a social grouping comprised largely of landowners, although lawyers and servants of the Crown also tended to fall within its bounds. Once considered the lowest part of the nobility, by the sixteenth century they had evolved to the point where they were essentially a caste unto themselves, and outnumbered the aristocracy by a factor of roughly ten to one. ${ }^{26}$ While the ownership of land was not a prerequisite for gentility, it was the only way of ensuring one's descendants maintained that status, making this a prime consideration in

\footnotetext{
${ }^{22}$ Cecil to Herle, 10 August 1573, BL MS Lansdowne 21, f.31v; see below p.68 for further discussion of this letter.

${ }^{23}$ Herle to Cecil, 14 February, 1559, TNA SP 70/11/316, f.63r-63v.

${ }^{24}$ Herle to Cecil, 6 August, 1587, BL MS Lansdowne 54, f.150r.

${ }^{25}$ BL MS Lansdowne 21, f.31v.

${ }^{26}$ Joyce Youings, Sixteenth Century England, Harmondsworth, 1984, p.116.
} 
marriage negotiations, though Herle does not seem to have concerned himself overly with this.

Little is known of Herle's family - his father was Thomas Herle of Montgomeryshire, and he had a sister who he remained close to throughout his life. ${ }^{27}$ There are no records of Herle marrying, although it seems he had an illegitimate daughter with one Rosa Jones, who was baptised Jana at Guilsfield, Montgomeryshire, on 23 October $1576 .^{28}$ While Herle himself did not marry, he maintained a close relationship with his sister and her husband Laurence Johnson. In fact Herle dictated letters to his brother-in-law when he was particularly ill himself and unable to write. ${ }^{29}$ His sister died sometime in the early 1580 s, and Herle took responsibility for 'the mayntenance \& bryngyng up' of her four 'poore lyttel ynffants,' consigning a government pension he had earned through his service to paying for their upbringing. ${ }^{30}$

Herle was clearly well educated, since a number of his letters indicate fluency in Latin, French, Dutch, Flemish, German, Italian, Spanish, and Portuguese. In a 1587 letter to Cecil Herle stated 'I owe to your L[ordship] mi education,' indicating that these skills were likely gained through tutelage organised by Cecil. ${ }^{31}$ However, no record of his enrolment at Oxford, Cambridge, or any of the Inns of Court survives. Nor is there any record of the passport he would have required in the unlikely event that he studied overseas. Edwards claims that Herle was forced to leave Oxford in disgrace to escape murder charges, a rather salacious claim based on a letter from Sir Edward Sanders, Chief Justice of the King's Bench, to Cecil, which mentions that a 'Mr Hearle' had

\footnotetext{
${ }^{27}$ Lewis Jones, 'William Herle and the Office of Rhaglaw in Elizabethan Cardiganshire,' p.180.

${ }^{28}$ Lewis Jones, 'William Herle (d. 1588/9).'

${ }^{29}$ Johnson's hand was significantly neater than Herle's own, as he wrote with a less hurried and cramped form of the secretary hand. In cases such as this Herle tended to annotate the letters heavily in their margins; See for example Herle to Cecil, 29 March 1575, TNA SP 70/137/59, ff.310r-311v.

${ }^{30}$ Herle to Walsingham, 13 June 1582, TNA SP 83/16/34, f.65v; Herle to Cecil, 19 February 1579, BL MS Lansdowne 29, f.134r.

${ }^{31}$ BL MS Lansdowne 54, f.150r.
} 
killed 'one Paul Penye, servant unto Sir Leonard Chamberlain. ${ }^{32}$ Aside from this passing mention there is nothing to support Edwards' theory, or tie this 'Hearle' to William Herle. It seems likely that it is based more on Edwards' wish to characterise Herle as a criminal than in fact.

\section{Herle's Entry into Government Service}

Our first documentary evidence of Herle's life indicates that he entered government employ alongside Cecil upon the latter's return to favour with Elizabeth's accession to the throne. In a 1587 letter to Cecil, Herle described himself as having 'served her majestie from the begyneng of her Raigne,' a fact of which he was justifiably proud. ${ }^{33}$ Similarly, when writing to Elizabeth in 1587 , Herle stated that 'mi service \& sincerity is best knowen by the space of 28 yeres, \& od moneths. ${ }^{, 34}$ No records survive of Herle being in Cecil's employment before Elizabeth took the throne, but as Cecil is the only obvious connection to the crown for Herle it is likely Herle had worked for him before.

In 1587, thanking Cecil for his aid throughout their years together, Herle said that he was ‘drawen only [to the Queen's service] by your good L[ordship] therunto, from Sir William Garrards howse. ${ }^{, 35}$ Garrard was a successful London merchant who had grown rich from the cloth export trade to Antwerp, although by the 1550s he had diversified to luxury goods and slaves, as well as taking governorship of the Russia Company. ${ }^{36}$ Given Herle's estimated birth date of somewhere in the 1530 s, he could not have been in Garrard's service for long before Cecil recruited him. When combined with Cecil's previous role in Edward's government, in which Herle is never mentioned,

\footnotetext{
${ }^{32}$ Francis Edwards, The Marvellous Chance: Thomas Howard, Fourth Duke of Norfolk and the Ridolfi Plot, London, 1968, p.39; Edward Saunders to Cecil, 17 March, 1559, TNA SP 12/3, f.113r.

${ }^{33}$ BL MS Lansdowne 54, f.150r.

${ }^{34}$ Herle to Elizabeth I, 10 April 1587, BL MS Lansdowne 54, f.151r.

${ }^{35}$ BL MS Lansdowne 54, 150r.

${ }^{36}$ Helen Miller, 'Sir William Garrard (c.1510-1571),' ODNB, http://www.oxforddnb.com/view/article/ 37441, accessed 11 May 2010.
} 
the likeliest scenario is that Herle entered Cecil's service towards the end of Mary Tudor's reign when Cecil was positioning himself for Elizabeth's accession.

Cecil's early career had been promising, but he gained real power through his relationship with the new Queen, who trusted his advice. Beginning as secretary to Edward Seymour, Duke of Somerset, he had survived Somerset's fall to become Secretary of State under the Duke of Northumberland. This service culminated in his knighthood on 11 October 1551. Cecil's rise halted upon the staunchly Catholic Mary Tudor's accession. Historians' traditional view is that Cecil disappeared from public office for the duration of Mary's reign, only returning to his previous position when Elizabeth was crowned. ${ }^{37}$

Stephen Alford, however, has recently argued that Cecil lived a double life under Mary, outwardly conforming to what was expected of him while secretly criticising the Catholic Queen and her government by supporting John Day's underground Protestant press. Alford further contests that Cecil did not become the recluse he is often portrayed as over this period, and he 'flirted with office' in the new government. ${ }^{38}$ During Mary's reign Cecil was known, even favoured, at court and maintained his political and social connections. He was far too talented a man to slip into obscurity, and in late February 1558 he took his chance at a return to power, organising a confidential meeting with Elizabeth. When Mary died on 17 November 1558, Cecil was already working as Elizabeth's Secretary of State, although he was not formally appointed until the twentieth. ${ }^{39}$

The office of Secretary of State had steadily grown in importance throughout the early modern period, and under Cecil became the most important office in England. As McCaffrey has noted, the fact that all official correspondence flowed through Cecil's

\footnotetext{
37 Wallace T. MacCaffrey, 'William Cecil, first Baron Burghley (1520/21-1598),' ODNB, http://www.oxford dnb.com/view/article/4983, accessed 11 May 2010.

${ }^{38}$ Alford, pp.70-72.

${ }^{39}$ ibid., pp.81-82.
} 
office allowed him a unique level of control over the realm's public business. ${ }^{40}$ As Secretary, Cecil emphasised certain attributes amongst those in his service, placing a premium on secrecy, intelligence, and information gathering. ${ }^{41}$ Herle clearly had all the attributes the Secretary needed amongst his employees, exhibiting an obsession with secrecy and the passing of private information that rivalled Cecil's own. From the start of the young Queen's reign, Cecil's was the dominant voice in the new government, and those with ties to him were well positioned to reap the benefits of his rapid elevation.

\section{Negotiating Government Loans}

In February 1559 William Herle wrote to Cecil from Antwerp, in the Spanish Netherlands. ${ }^{42}$ This was not Herle's first epistolary contact with Cecil, as he refers to earlier letters sent when in Dunkirk, but it is the earliest surviving document relating to Herle's life. Herle reported rumours of nobles gathering in Germany in response to the King of Poland's death, a fact which Herle was clearly mistaken about as Sigismund II was alive and well in 1559. While the accuracy of Herle's intelligence is certainly questionable, the potential importance is not. As Secretary, Cecil needed information on continental politics, and risked the occasional premature report such as Herle's in order to encourage timely updates. Herle comes across as a young man, eager to perform his service well and ingratiate himself with his powerful patron. He emphasised his 'good zele to serve mi charge under your mastership, bothe faythfully \& dilygentlye. ${ }^{43}$ Even though the letter is a mere fifteen lines, minute in comparison to Herle's later reports which often ran from three to five pages, various details within it carry forward throughout Herle's life.

Herle's location in Antwerp from where he sent the letter is particularly significant when seen in light of his later career. Ties to the Netherlands were a

\footnotetext{
${ }^{40}$ MacCaffrey, 'William Cecil, first Baron Burghley (1520/21-1598).'

${ }^{41}$ Morrison, p.223.

${ }^{42}$ TNA SP 70/11/316, f.63r-63v.

${ }^{43}$ ibid., f.63v.
} 
continued theme throughout Herle's life, with his extended stays there vastly outnumbering his other overseas postings. Antwerp was vital to England's strategic interests, as the centre of its wool exports and financial dealings. It was therefore a natural place for government agents to gather. Herle's mission to Antwerp must have been a success, as when he next appeared in the records, Herle was undertaking significantly more important work for Cecil.

In early April 1560, Herle was in Europe organising loans on behalf of the government, and writing of his efforts to Sir Thomas Parry. ${ }^{44}$ It seems he travelled under the guise of a merchant, discussing rates of interest and the availability of cheap credit with merchant bankers in the aftermath of wars amongst the Germanic states. Herle's previous work with Garrard made him a natural choice for this role, and probably allowed him to blend in with relative ease. While Herle was in Hamburg, a merchant named Henrick Rantzow told him that there was so much ready cash in Antwerp that loans could be had for a lessened rate, and that he hoped that through his 'mene no small som shold have ben employed to th'use of your englyssh nacion.' ${ }^{45}$ It seems that Herle had been attempting to set up loans from Rantzow and the other merchants he represented for a time the previous summer, but negotiations had collapsed when Herle was forced to return to England abruptly. There is no indication in Herle's letter of why he would have needed to leave so abruptly, although given his later problems it seems likely that the cost of acting on the government's behalf was proving prohibitive.

Herle travelled on to Bavaria, where he contacted the merchants again, discussing details for the proposed loan. Herle offered 'th'assuraunce to obtain the

\footnotetext{
${ }^{44}$ Parry was a significant figure in the early Elizabethan government, rivalling Cecil for influence until his death in December 1559. As Parry had been dead for almost four months when Herle wrote to him, Herle must have been out of England for a significant length of time before making this report: Jonathan Hughes, 'Sir Thomas Parry (1515-1560),' ODNB, http://www.oxforddnb.com/view/article/21433, accessed 11 May 2010.

${ }^{45}$ Herle to Thomas Parry, 7 April 1560, TNA SP 70/13/451, ff.29r-29v.
} 
Cytye of Londons bond' for a loan of $£ 20-30,000 .{ }^{46}$ Unfortunately for Herle the merchants had little money left to lend, as the combatants in recent wars amongst the German princes had yet to repay their loans. Herle informed Parry that the merchants would be able to scrape together little more than a third of the required sum, but that if he was given sufficient authority he could garner the full amount by 'Christmas next. ${ }^{47}$

In January 1561 Herle received detailed instructions from the Queen regarding his powers in negotiating loans and the need for him to do so. At this point Herle was in Hamburg, so it seems likely that Cecil had ordered him to Europe in anticipation of the Queen's permission to negotiate loans. These instructions were merely formalising what he was already intended to do, and Elizabeth intimated this when she said that 'we have perceyved by your 1[ett]res...to our principall Secretary...that...yow have obteynid the loane. ${ }^{48}$ The loan in question was for $£ 80,000$ and 50,000 crowns, 'upon six in the hundred, to be delyverid at Hambourgh abowt the next Aprill.' The interest of six percent was a problem for Elizabeth, who wished Herle to 'obteyne it upon fowre or fyve at the most per cento.' She was also uncomfortable with the fact that the bankers required 'two of the thre Marityme Cites, Hambourgh, Lubeck, and Lunenbourgh' to provide surety of repayment, rather than her own bond. ${ }^{49}$ Overall, however, she seemed pleased with Herle's accomplishments, and ordered him to see if a similar loan would be available at Emden.

While organising these loans for the government, Herle was undertaking a sideline in information gathering, a typical occurrence in the informal English intelligence community. Cecil, Leicester, and Walsingham all had private networks of contacts who acted for them in other capacities while feeding information to the Councillors as a favour. Intelligence gathering methods were crude, and much of the

\footnotetext{
${ }^{46}$ ibid., f.32r.

${ }^{47}$ ibid., f.32v.

${ }^{48}$ Elizabeth I to Herle, 2 January 1561, BL MS Cotton Titus BV, f.171r.

${ }^{49}$ ibid.
} 
data gathered amounted to little more than local gossip. The method Herle planned to use to gather information in this instance, was to go to taverns with merchants and, 'when they lie dronke,' 'feadinge of theire humor and inclynacon,' take advantage of the situation to lead them into revealing more information than they would sober. ${ }^{50} \mathrm{He}$ obviously experienced some success with this plan.

Herle's intelligence focus in this series of letters was on detailing the connections that his merchant contact Rantzow had at the Danish court. He felt this particularly important because of the 'ancyent amitye which ever was betwixt the howse of Denmarke \& Frawnce,' giving Rantzow, and through him Herle, insight into French plans to aid Scottish rebels against England. ${ }^{51}$ Yet Herle also raised more general concerns, reporting on such minor matters as Westphalius of Hamburg railing at England and its chief magistrates in an open pulpit without check from the authorities. This intertwining of minor details more indicative of local colour than national importance, and potentially explosive information appears throughout the corpus of Herle's letters. By placing concrete details of minor matters and nebulous information about more significant ones in such close proximity, Herle lent a subtle credibility to each statement that would have been lacking had each been presented in isolation.

Between 1561 and 1563 Herle disappears from official records once more, only reappearing when he returned to Europe for further loan negotiations. In May 1563 he wrote to Cecil reporting his arrival at Antwerp, and detailing what intelligence he had gleaned on his way north from Dunkirk. He briefly detailed a conflict between the Kings of Sweden and Denmark, rumours of negotiations between the Russians and the Danes, and movements of the Spanish navy to counteract a planned Turkish invasion of Corsica. Herle was also running short of funds, asking Cecil for 'a 1[ett]re of credit for a

\footnotetext{
${ }^{50}$ Herle to Unknown, 28 May 1560, TNA SP 70/14/73, f.114r.

${ }^{51}$ TNA SP 70/13/451, f.30v-31r.
} 
foure or fyve hundrethe crownes. ${ }^{52}$ This was necessary as he had been 'consumed with long expenses this laste yere, and yet reqwiringe no allowaunce till my purpose be perfected.' Ambassadors and agents such as Herle generally paid their own way then attempted to recoup expenses after the fact. Convincing Elizabeth and Cecil to compensate Herle for losses incurred in their service proved Herle's greatest problem during the course of his life, and he experienced little success in doing so.

From a series of letters across August-November 1563, it is clear that Herle's primary purpose upon the continent was once again negotiating loans. By 2 August 1563, Herle had completed his business in Antwerp, informing Cecil that 'mi charge being to your full contentment fynisshed' he carried a contract for $£ 37,000$ 'under their fyrme \& seales. ${ }^{53}$ Herle's time on the continent had obviously been extended, and he bemoaned the fact that 'in the mene season I was forced' to borrow $£ 100$ 'in Andwerpe, for furniture of mi busynes \& charges.' While he mentioned that he would like to be reimbursed upon his return, Herle's primary concern was gaining timely transport across the Channel, and he asked that Cecil aid him in this.

Unfortunately for Herle, Cecil does not seem to have been the most attentive patron at this point. On 13 October 1563, two months after he asked Cecil for assistance, Herle still waited in Dunkirk for a ship to take him across to Dover. In the intervening months he had taken ill, 'shaken with a meane agew,' and could 'scarse write ani thing to your honor presently for wekenes. ${ }^{54}$ He repeated his pleas of August, adding the detail that the banker whose loan he had organised had sent his principal clerk to carry over the legal documents with Herle, and they both now waited for transport. In addition to asking for 'credyte of 2 or 300 [crowns] with Richard Clough to satisffye suche chargs as by waye of credyte I was fayne to take up,' Herle requested

\footnotetext{
${ }^{52}$ Herle to Cecil, 6 May 1563, BL MS Lansdowne 7, f.52v.

${ }^{53}$ Herle to Cecil, 2 August 1563, BL MS Lansdowne 7, f.66r.

${ }^{54}$ Herle to Cecil, 13 October 1563, BL MS Lansdowne 7, f.71r.
} 
'your honors authoritye for som smal vessell of good conduct over.' ${ }^{55}$ Two weeks later Herle was still waiting.

By 26 October, Herle was becoming frustrated at the lack of aid he received from Cecil, decrying that in his last letter 'dyd I certeffye throwlye the state of mi busynes, wherin wanted nothing butt mi comyng over, all other things were determyned, \& fullye concluded upon. ${ }^{56}$ As he had received no answer from the Secretary, Herle planned to write to 'Maye of Dover for mi spedye transport' across the Channel. This would not solve his credit problem however, and he begged Cecil for aid. On 5 November Herle repeated this letter, informing him that:

I sollycyte styll on thing Right honorable, \& in respect of mi servyce well fynisshed, do confydentlye attend som credyte of 300 [crowns] to dispatche me hence, the which most willinglye I wold refferre to mi comyng over, so my promis \& faythe were nott presentlye to be discharged beffore mi departure. ${ }^{57}$

This indicates Herle had been able to procure passage across the Channel without Cecil's aid, but felt unable to leave the continent until his loans had been repaid. Clearly Herle was worried about his continued credibility in the Low Countries. No further letters in this sequence survive, and Herle's next contact with Cecil was not until September $1564 .^{58}$ Herle had clearly returned to England by this point, although we cannot be sure when in the intervening ten months Cecil had brought him home.

For a short period then, Herle was acting as an organiser of government loans, roughly analogous to a less empowered version of Sir Thomas Gresham, the founder of the Royal Exchange. Gresham spent a significant portion of his time between 1551 and 1564 in Antwerp raising credit and consolidating loans at the money market there. ${ }^{59} \mathrm{He}$ also acted as a merchant, trading for himself while steadily reducing government debts

\footnotetext{
${ }^{55}$ ibid., ff.71v-72r.

${ }^{56}$ Herle to Cecil, 26 October 1563, BL MS Lansdowne 7, f.73r.

${ }^{57}$ Herle to Cecil, 5 November 1563, BL MS Lansdowne 7, f.75r.

${ }^{58}$ Herle to Cecil, September 1564, TNA SP 12/34/66, ff.182r-183v.

${ }^{59}$ Ian Blanchard, 'Sir Thomas Gresham (c.1518-1579),' ODNB, http://www.oxforddnb.com/view/article/ 11505, accessed 11 May 2010.
} 
run up during Mary's reign. Herle's role as a loan negotiator was an entirely respectable one, and likely a sign of a young man on the rise.

Herle's success in his early loan raising and intelligence gathering work can be seen in the substantial reward he received from the Crown in 1565. In partnership with Armagil Waad, Herle received a patent for manufacturing sulphur and oil. ${ }^{60}$ Couched in the formal language of royal proclamations, the patent acknowledged that the two men had discovered a new process for the creation of flax seed oil, and granted them exclusive rights to pursue such measures within Elizabeth's realm for the next thirty years. This patent was clearly a reward for Herle's dutiful service, and it seems likely that Cecil had persuaded the Queen to aid his client in this way. It would seem that 1565 started out as the culmination of years of dedicated service on Herle's part. Soon after Herle received this reward, however, his career prospects began to fall apart. Over the next few years, Herle was involved in a series of disastrous court cases that forever tarnished his reputation.

\section{Herle's Foray into Piracy}

In both 1565 and 1570, William Herle was arrested on charges of piracy. That Herle, a respectable member of the gentry, should find himself in such a seemingly nefarious "trade" seems strange. However, sixteenth century England had a substantial piratical fleet, stemming largely from changes in the fishing industry. As an island nation where fish was a staple of most people's diet, England maintained significant fishing fleets and used these as a training ground for mariners to defend the realm in times of need. Across the Tudor period, Dutch fishermen gradually grew to dominate the waters around England, due to their superior vessels and ability to salt vast

60 'Ad Sulpher \& Oleum conficiendum de Concessione,' 1565, in Thomas Rymer (ed.), Foedera, Conventiones, Literae et Cujuscunque Generis Acta Publica, Inter Reges Angliae, et Angliae et Alois Quosvis Imperatores, Reges, Pontifices, Principes, Vel Communitates, Vol.15, London: A \& J Churchill, 1713, pp.650-651. 
quantities of fish onboard. ${ }^{61}$ The English response to this change was twofold: at the parliamentary level, legislation was enacted to force Englishmen to buy from English fishermen rather than Dutch; at the local level, many fishermen turned to piracy to make ends meet. Geoffrey Elton exhaustively detailed the former process, but the latter has been largely overlooked by historical scholarship. ${ }^{62}$

England had a long tradition of piracy, which the formation of the league of the Cinque Ports in the fourteenth century had done little to ameliorate. ${ }^{63}$ The league was intended to protect the south-east coast and police the seas. In fact, by granting members the prerogative to plunder non-English ships which passed through the Channel, the Ports merely regulated piracy into a commercial weapon. Attempts made by Elizabeth's grandfather, Henry VII, to check piracy through the issuing of letters of marque which entitled the bearer to seize goods of an equivalent value from the nation of those who had robbed him exacerbated the problem, and by the mid-sixteenth century English waters were notoriously dangerous. ${ }^{64}$

Throughout Elizabeth's reign, piracy was a constant menace to sea trade. By the 1560s the French Wars of Religion and the Dutch Revolt had caused a general breakdown of central authority across the north-west coast of Europe, leaving large areas of the coast unpatrolled and intensifying the pirate problem. Portuguese and Spanish ships were the most common targets for English pirates, due in large part to their use of Antwerp as the prime location for distributing their merchandise into central and northern Europe. The principle route from the Iberian peninsula to Antwerp lay through the English Channel, past the south coast from Cornwall to Kent. ${ }^{65}$ In addition to supporting semi-official piracy through the Cinque Ports, these areas were dotted

${ }^{61}$ Geoffrey R. Elton, 'Piscatorial Politics in the Early Parliaments of Elizabeth I,' Studies in Tudor and Stuart Politics and Government: Volume IV, Cambridge, 1992, p.111.

62 ibid., pp.109-130.

${ }^{63}$ The Cinque Ports were initially five towns: Hastings, Romney, Hythe, Dover, and Sandwich. Later Winchelsea and Rye were added.

${ }^{64}$ Philip Gosse, The History of Piracy, London, 1934, pp.96, 102.

${ }^{65}$ ibid., pp.104-105. 
with the sort of small fishing villages and isolated coves that encouraged small-scale piratical behaviour.

A number of measures were suggested to lessen the pirate problem. In his General and Rare Memorials John Dee argued that a 'Pety-Nauy-Royall' could be maintained at minimal expense and expanded as needed. ${ }^{66}$ All the 'pyrats, our own cuntrymen' could be absorbed into this navy, both preventing their further predations, and making use of 'their bodyes (already hardened to the seas) and chiefly of their courage and skills.' Dee's suggestion was implemented when the onset of the Spanish war necessitated the employment of a large number of former pirates in the navy. The natural outcome of this was that entrepreneurial piracy rapidly diminished. In 1565 when Herle was arrested, however, piracy was still a major problem in England.

Herle's piratical activities were concentrated in the $1560 \mathrm{~s}$, a period when Elizabeth constantly vacillated about England's relations with Spain. While Valois France had descended into turmoil with the onset of the Wars of Religion in 1562, there was no indication yet that its weakened state would be permanent. In fact Herle's first bout of piracy, in 1565 , occurred during the period of relative peace within France following the 1563 Edict of Ambrose. England needed to maintain cordial relations with Habsburg Spain in order to preserve their alliance against France and Scotland. The thriving wool trade at Antwerp was also vital to English interests, necessitating close ties with the Spanish authorities in the Netherlands. Attacks on Spanish ships travelling to the Low Countries, then, were likely to be frowned upon by the Crown.

In mid 1565 a ship hailing from the Spanish Netherlands was attacked by English pirates, who made off with its cargo. Herle was entangled enough in this raid on Spanish shipping that the High Court of Admiralty, as part of its investigation into the incident, required him to give a deposition detailing his involvement. No full record of

\footnotetext{
${ }^{66}$ John Dee, General and Rare Memorials Pertayning to the Perfect Arte of Nauigation, London: John Day, 1577, STC 6459, A.ii.r-A.iii.v.
} 
the case survives, although Admiralty Court sessions were largely formalities, more about observing due process before passing judgement than investigating evidence. ${ }^{67}$ However, the depositions of Luke Spracklinge, Mary Best, and William Herle survive, the former accusing Herle of complicity in piracy, and the latter defending himself.

Spracklinge, a 'sercher' or customs official, based in the coastal town of Margate in Kent, deposed on 25 July 1565 . He related how on 4 July two men sailing with Herle informed him that Herle's ship was docked nearby. Spracklinge was delighted to hear this as Herle owed him $£ 417$ s, a sum which he immediately set out to collect. Unable to find Herle aboard the ship, Spracklinge was entertained by Charles Morehouse, who 'declared to him that Herle and he had a licence from the Kinge of Swethland [Sweden] to apprehend and take all suche shipps and goods as did appertaine to any of his enymies. ${ }^{68}$ The ship remained there until 10 July, its occupants hoping that Spracklinge would sell them provisions, but he refused as he suspected 'that they should be pirats.'

Mary Best, another Margate local, gave evidence that Herle and four others had lodged at her house one night. Best thought this odd, as Herle usually stayed with Spracklinge when he was in Margate. Further rousing her suspicions was the 'great bage' filled with 'divers peeces of goold' that one of Herle's companions carried, a possible sign of the profits of their piracy. ${ }^{69}$ Best's comments place Spracklinge's deposition in an interesting light. He and Herle were clearly old friends, as 'Herle was accustomably used to lodge at the sayd serchers howse.' Furthermore, Best's belief that she saw a man carrying a sack of gold, if accurate, indicates that Herle and his companions had brought significant spoils with them. Perhaps Spracklinge was more involved in the piratical activities than he let on, and his accusations were less about a

\footnotetext{
${ }^{67}$ Evelyn Berckman, Victims of Piracy: The Admiralty Court, 1575-1678, London, 1979, pp.5-6.

${ }^{68}$ Depositions of Luke Spracklinge and Mary Best, 25 July 1565, TNA HCA, 1/26/393, ff.393r-394v. 69 ibid.
} 
concerned citizen warning the authorities than they were the outcome of a disagreement over the division of spoils.

On 2 August, Margaret, Duchess of Parma and Governor of the Netherlands, wrote to Elizabeth complaining of 'several depredations carried out previously by subjects of your Majesty, and recently (among others) by one Willem Eerle at the very mouth of the Thames. ${ }^{70}$ Further, the Duchess claimed that these pirates had been carrying their winnings ashore and selling them under the eyes of the authorities. This was particularly galling, as Elizabeth had recently promised to crack down on piracy during their negotiations in Bruges for continued peace. In light of her 'respect for the firm friendship existing between your Majesties [Philip and Elizabeth],' the Duchess had ignored pleas for restitution through the seizure of English cloth ships in Antwerp, but unless Elizabeth responded to these grievances she would feel compelled to do so herself.

The authorities reacted quickly to Margaret's complaint, calling Spracklinge to a second deposition. ${ }^{71}$ Spracklinge gave additional evidence about the Swedish letter of marque Herle and Morehouse had been granted, claiming they showed it to him at Dover the year before but he had been unable to read it as it was in Latin. When he went aboard Morehouse's ship to look for Herle on 4 July, he was told Herle had gone ashore the night before and would come to see him at his house. Herle's position onboard the ship is unclear. Morehouse was evidently the captain, but Spracklinge was unsure if Herle was 'owner, capitaigne, peticapitaigne or howe he served.'

In response to Spracklinge's accusation of piracy, Herle gave his own deposition to the court. ${ }^{72}$ Furthermore, on 3 August 1565, Herle sent Cecil a letter explaining why he had recently been caught in the company of pirates. Enclosed within the letter is a

\footnotetext{
${ }^{70}$ Margaret to Elizabeth, 2 August 1565, BL Cotton Galba CII, (Jean Anderson trans.), f.166r.

${ }^{71}$ Deposition of Luke Spracklinge, 6 August, 1565, TNA HCA, 1/26/393, f. 395v.

${ }^{72}$ Herle's Deposition, August 1565, TNA HCA, 1/38/16, ff.16r-18v.
} 
detailed diary of his movements over the course of July, Herle's attempt to prove to his patron that he was not involved in anything as untoward as piracy. ${ }^{73} \mathrm{He}$ was quick to assure Cecil that he had been staying 'in company of honest gentyllmen \& well knowen,' not scoundrels. The details given in his diary and deposition, however, indicate that this was not entirely the case.

In his deposition, Herle claimed that he had been travelling with William Wilson, another of those Spracklinge accused of piracy, as Wilson owed him a debt. Wilson promised to repay Herle out of his cut from the first ship they captured while sailing under commission. Herle claimed that he been told by 'lerned men that suche service was not unlawfull, butt approved by sondrye arguments \& presydents agaynst Ffrance \& agaynst Fflanders. ${ }^{74}$ While there is a degree of logic to the idea that French ships could be robbed legitimately, given the tacit support England showed to the Huguenot rebels, Herle's claim that the Spanish Netherlands were an approved target seems odd. Elizabeth and her councillors were carefully avoiding provoking Spain in this period, and attacking vessels from a Spanish possession would be a reversal of this policy.

Herle also argued that he had been on the ship 'as a private person, nether captayn as som say, nor owner, vyttayler, adventurer, nor servitor in that jorney,' and was therefore not responsible for the actions of others on the ship. ${ }^{75}$ No evidence survives of who it was that said Herle was captain of the ship, as neither Spracklinge or Best's statements do more than say that they were unsure of Herle's role. It is likely that Herle was referring here to rumour rather than an actual charge. With a number of weeks having passed since Spracklinge's initial deposition, there was ample time for details of the investigation into Herle's doings to have spread.

\footnotetext{
${ }^{73}$ Herle to Cecil, 31 July 1565, TNA SP 15/12/76, ff.224r-226v.

${ }^{74}$ TNA HCA, 1/38/16, f.16r.

${ }^{75}$ ibid.
} 
After weeks of beating against the prevailing winds with Wilson, claimed Herle, he jumped ship and returned to England on a vessel captained by William Monck, a servant of Thomas Howard, the Duke of Norfolk. He lodged in Weymouth for a few days, until he was contacted by one of Wilson's men who told him that 'they had taken a dansker laden with sallt' and if he would travel to the Isle of Wight where they were berthed, he "shold have satisfactyon of my monney presentlye. ${ }^{76}$ Herle went on to Dorset to speak with Norfolk, asking him for permission to sell the salt in his shire, but the Duke told him he would have to seek permission from the Queen. There is no evidence of Herle having further contact with Norfolk, and it seems this was purely a business transaction, with Herle taking advantage of Monck's connection to Norfolk to sell off the plundered goods quickly. Given Herle's later involvement in exposing the Ridolfi plot that led to Norfolk's execution, however, this meeting with the Duke is certainly an interesting coincidence.

Herle travelled on to the Isle of Wight to report this setback to Wilson, but was apprehended by the Vice-Admiral's men on suspicion of being captain of a pirate ship. Herle was released upon showing the Vice-Admiral a letter he had from Wilson disproving this accusation. Perhaps more telling is that Herle offered to "perswade with Willson \& Morehowse \& with the better sort of the ship to bring in their prise' and turn themselves in, in exchange for a lighter sentence. ${ }^{77}$ Herle claimed he attempted to do so, but that the others refused to return with him, and further carried him off so that he was unable to return alone. Despite this, he claimed, they remained 'in that degre of dutifulnes to their prince, as they wold do nothing which were unsemelye' and so returned to Weymouth. ${ }^{78}$

\footnotetext{
${ }^{76}$ ibid.

77 ibid., f.17r.

${ }^{78}$ Herle to Cecil, 3 August 1565, TNA SP 15/12/76,f.221r.
} 
No record survives of the outcome of Herle's trial, but it seems his account of his doings was enough to satisfy the Court. Given his appeal to Cecil, it is even possible that the Secretary interceded on his servant's behalf. Cecil, however, could not have been happy with his servant's antics, and one imagines he made his displeasure known to Herle. None of Herle's letters state why he would have risked Cecil's ire by turning pirate, although his letters of the next few years hint that he was trying to pay off the debts he incurred while organising loans overseas.

In December 1569 Herle wrote to Cecil, asking him for financial aid. As Herle's primary patron, Cecil was the natural man for Herle to turn to in his hour of need, and it seems he was in dire straits:

I know your hevy cowntenance towards me hath bin grett, which partly mi supplanters have incresed, \& partly those ynfelicityes have bred, which communely follow a nedy man: yett mi ynnocency doth so assure me again, if I may be indiffrently hard, with mi contynuall devotion borne to your honor, as pardonably I presume to write these few lynes unto yow. ${ }^{79}$

Herle's mention of Cecil's 'hevy cowntenance towards me' further indicates that all was not well in their relationship by 1569. A large part of Cecil's displeasure can likely be laid at the feet of the 'ynfelicityes' Herle mentioned. Having gone from a useful negotiator and travelling loan organiser to a pirate who Cecil was forced to save from prison, Herle's stock with his patron was plummeting. His early promise seems very much to have dwindled, and the Secretary must have wondered what he ever saw in Herle. The mention of 'mi supplanters' is also interesting. Clearly Herle felt that there were those around Cecil who were undermining his relationship with the Secretary, perhaps in an attempt to increase their own ties to Cecil. Herle's primary concern in this letter, however, was one which would dog him throughout his life.

Herle was interminably impecunious, and a large number of his letters are concerned with ameliorating this condition. By 1569 Herle asking Cecil for aid was an

${ }^{79}$ BL MS Lansdowne 12, f.36r. 
occurrence so common that he felt the need to preface many of his pleas with an apologetic acknowledgement of this fact. Despite not wishing to trouble his patron, Herle felt that his situation was so dire 'as non can be more, nott having had a peni in the world of myne own since mydsomer. ${ }^{80}$ Constantly hounded by creditors, Herle feared being placed in debtors' prison, a fate which befell him more than once. ${ }^{81}$ The men Herle was indebted to, he wrote, 'so vexe me with arrests \& charges... that I dare no more go owtt of doors. ${ }^{, 82}$

These debts had a vastly influential effect on Herle's life. Over the course of thirty years and almost three hundred letters, Herle's debts were often his central concern. While he employed a number of means in these attempts, his most commonly used method was working on government business abroad. This had the dual benefits of being work that Herle's linguistic skills gave him an aptitude for, and being out of the reach of his creditors. Significantly, letters to Cecil beginning for monetary relief or letters to ward off debtors greatly increased whenever Herle returned to London. In 1569, however, Cecil ignored Herle's pleas for financial aid. In a little over a year, Herle was imprisoned.

On 18 November 1570, the Privy Council met at Hampton Court. The second item on their agenda was a letter to the Knight Marshal 'to receve into his custodye John Keele, Avery Phillippes, John Poole, and William Herle. ${ }^{83}$ He was to keep the four men isolated in 'severall wardes, suffering none of them to have conference with another,' and allowing 'no other to have conference with them.' During the winter of 1570-71 William Herle languished in the Marshalsea prison. Located on the south bank of the Thames, it had been the traditional place of internment for London's debtors

\footnotetext{
${ }^{80}$ Herle to Cecil, 18 January 1572, BL MS Lansdowne 16, f.80r.

${ }^{81}$ See pages $50 \mathrm{ff}$., and $75 \mathrm{ff}$.

${ }^{82}$ BL MS Lansdowne 16, f.80r.

${ }^{83}$ J.R. Dasent (ed.), Acts of the Privy Council of England: Volume VII, London, 1893, p.401.
} 
since the fourteenth century. ${ }^{84}$ When combined with Herle's history of poor financial management, one's first assumption would be that he was in prison because of his bad debts, rotting there until his friends could gather the funds required to procure his release. In fact, it seems Herle had been implicated in piratical activities again, and this time was unable to talk his way out of it.

Writing to Sir Francis Bacon, Elizabeth's Lord Keeper, Herle begged for release from the Marshalsea. He bemoaned how life had treated him badly, that no matter how hard he worked 'in place of gaine I have losse, \& for prefferment destruction. ${ }^{85}$ While this was perhaps a little melodramatic, Herle's conclusion cannot really be gainsaid. After working tirelessly for Cecil and Elizabeth for almost a decade, he seems to have gained remarkably little in the way of rewards. His difficulty in gaining recompense for the expenses he ran up in Crown service could very well have been what reduced his finances to such a level that he turned to piracy.

Herle's customary lack of ready cash reared its head when he claimed that those who were arrested alongside him had since bought their way out, while he remained stuck in prison 'wholy voyd bothe of mony, creditt \& apparayll. ${ }^{86}$ Presumably Keele, Phillippes, and Poole had managed to scrounge together the funds required for their release in the two months since the four of them were imprisoned. Herle instead offered his service in a task 'of importance to her Majestie' in exchange for his freedom.

At first glance it seems odd that Herle would appeal to Bacon when he had established a close relationship with Cecil over the preceding decade. However, it is possible that the Secretary's 'hevy cowntenance' still weighed on Herle's mind. ${ }^{87}$ Perhaps he felt that his demands on his patron were growing too frequent to maintain balance in their relationship, perhaps he was leery of asking Cecil for help when he had

\footnotetext{
${ }^{84}$ Charles Nicholl, The Reckoning: The Murder of Christopher Marlowe, London, 1992, p.135.

${ }^{85}$ Herle to Bacon, 8 January 1571, TNA SP 12/77/1, f.1r.

${ }^{86}$ ibid.

${ }^{87}$ BL MS Lansdowne 12, f.36r.
} 
been bailed out of similar trouble before. Whatever the reason, it is clear that Herle felt it prudent to avoid reminding Cecil of his existence until it could be under less dire circumstances. No order for Herle's release survives, so it is impossible to know how his appeal to Bacon fared.

By April 1571 Herle was again funnelling information to the Secretary. An undated letter from Herle to Cecil, which was probably written at some point during this period based upon Herle's interest in piracy, puts forward a plan for eliminating piracy from Elizabeth's realm. ${ }^{88}$ It is possible that this letter was composed in 1565 , when Herle undertook his first piratical endeavours; however 1571 seems the more likely date as Herle's stay in prison would have given him ample time to muse on ways to regain Cecil's favour. Herle's plan to combat piracy essentially boiled down to a yearly survey of ships owned by each merchant and fisherman in the realm. According to Herle, this would let officials keep track of the movement and sale of ships, preventing ship owners from turning pirate on the side. Herle's proposal, particularly the idea that ship owners would fund this policing of their industry, seems naïve.

While Herle's plan for reforming England's sea trade was unlikely to appeal to Cecil, it was enough to remind the Secretary of his existence. In all likelihood Cecil arranged to have Herle released from prison, although it is possible that his friends scrounged together the cash required to pay his release fee. Given that we can place him in the Marshalsea again in March 1571; it is entirely possible that Herle remained there during the intervening months. Perhaps Cecil merely arranged for his bond to be paid, allowing him out into London but keeping a tight rein upon his activities. No matter what the full story was, Cecil was clearly interested in Herle once more.

${ }^{88}$ Herle to Cecil, [1571], BL Additional 34,729, ff. 79r - 80v. 
In this chapter we have seen how Herle entered government service at the beginning of Elizabeth's reign. Well educated, with some experience in the LondonAntwerp trade, Herle was a prime candidate for recruitment by William Cecil. The Secretary of State inducted Herle into the world of Tudor foreign relations, an area where great rewards were there for the taking, but where power and wealth was concentrated in the hands of a lucky few. While Herle performed his duties admirably, the casual nature of the Elizabethan civil service worked against him. Expected to pay his own way when on government service, Herle ran up debts that would plague him for the rest of his life.

Strands that would run throughout Herle's life surfaced here first. The coming conflict between Protestant England and the Continental Catholic powers was foreshadowed by Cecil's recognition of the strategic and political importance of the Netherlands. Herle's role in this conflict was also hinted at with Cecil's emphasis on the importance of rapidly transmitted accurate information. Herle's descent from loan negotiator to alleged pirate shows the lengths to which financial hardship could push even a respectable gentleman. Most importantly, we have seen how important a powerful patron was to a successful career in the Tudor civil service. It was only through Cecil's benefice that Herle could hope to ensure that his rewards for service outweighed the debts he incurred. While Herle ended this chapter languishing in prison, he was about to experience a life-changing shift in his career. After an extended lull in work, and with his reputation in tatters, Herle would receive an opportunity to ingratiate himself with Cecil to a degree he could never have managed through his loanorganising missions of the 1560s. 


\section{Chapter II: The Ridolfi Plot}

In April of 1571 William Herle was entrusted with an important mission. During the next few months, he would play a vital role in Cecil's attacks on Thomas Howard, the Duke of Norfolk, and Mary Stuart, exiled Queen of Scots and a devout Catholic. Mary and Norfolk challenged Cecil's position as foremost councillor and his unparalleled access to the Queen. While Herle played a comparatively small part in Cecil's attempt to discredit these powerful figures, it nevertheless proved vital to his relationship with Cecil, his position within Elizabethan society, and his continued employ in government service.

Cecil attacked Mary and Norfolk by creating a picture of an impending Catholic assault on the Protestant establishment. By weaving together a series of seemingly disparate incidents, Cecil created the impression of a coherent plot to depose Elizabeth and reinstitute Catholicism in England. Cecil and Walsingham repeatedly employed this tactic throughout the Elizabethan period. By creating a sense of imminent crisis the two strongly Protestant councillors managed to push the usually conservative queen into far more radical actions than she wished to take. The scheme detailed in this chapter, commonly referred to as the Ridolfi plot after its enigmatic instigator, was the final link in a chain of events stretching back to the late 1560 s.

This chapter considers William Herle's role in the Ridolfi plot, focusing on his second stint in the Marshalsea - this time as a government agent rather than a legitimate inmate. The letters Herle wrote to William Cecil, elevated to Lord Burghley in February of 1571, and John Leslie, the Bishop of Ross, from March to April of 1571 are the focus of both narrative and analysis. Cecil's summary of the plot and letters between other participants in the intrigue are also examined. Herle's role in the Ridolfi plot was a watershed moment in his life, transforming him from a disgraced negotiator to a useful 
intelligencer. The success he experienced here revitalised his career, and garnered him a number of rewards. Yet Herle remained deeply in debt, and his initial foray into intelligence gathering proved his most successful. This chapter will contrast Herle's work in uncovering the Ridolfi plot with a number of his less successful reports of other conspiracies.

\section{Cecilian Construction of Crises}

As a well documented example of Elizabethan treason, the Ridolfi plot has been discussed in passing by virtually every Elizabethan historian. Conyers Read provides a perfect example of the sort of view most historians have reading the Ridolfi plot, following Cecil's narrative of the plot almost exclusively. ${ }^{1}$ Francis Edwards, however, has consistently provided a counter to the more usual acceptance of the narratives of these incidents. The events of the Ridolfi plot seem fantastical to the modern reader, and Edwards has claimed that the plot was both too far-fetched and too convenient for William Cecil to be anything other than a Cecilian plan to eliminate Norfolk. Edwards' three books each focus on different aspects of the plot, the first on Mary's role, the second on Norfolk's, and the third on its place amongst the various plots of the Elizabethan era. ${ }^{2}$ All three consistently present Edwards' basic thesis: that the Ridolfi plot was a Cecilian construction, designed to discredit his enemies as traitorous Catholics and ensure his own continued hold on power. Cecil cynically crafted the plots from thin air as weapons for attacking his enemies.

Edwards questions the validity of the primary narratives of the various plots, based upon the fact that they occurred during what he describes as Cecil's domination, the period between 1558 and 1612 where William Cecil and his son Robert

\footnotetext{
${ }^{1}$ Read, Lord Burghley, pp.38-50.

${ }^{2}$ Francis Edwards, The Dangerous Queen, London, 1964; Edwards, The Marvellous Chance; Francis Edwards, Plots and Plotters in the Reign of Elizabeth I, Dublin, 2002.
} 
overshadowed English politics. ${ }^{3}$ The Ridolfi plot was the first in a long line of similar smear campaigns conducted by the Cecils to bolster solidarity against Catholicism amongst English Protestants. Edwards invests the Cecils with a Machiavellian willingness to corrupt historical perception of these events through distorting public records and destroying private ones, including those of the Duke of Norfolk, the Earls of Oxford and Leicester, and Sir Francis Walsingham. ${ }^{4}$

Edwards' identification of Walsingham as a target of Cecilian distortion would seem to undermine his thesis somewhat, given the commonality of interest between Cecil and Walsingham. While Walsingham was the acknowledged instigator of antiCatholicism for much of Elizabeth's reign, at this point Cecil was the most prominent and powerful Protestant in England. Although historians have generally portrayed Cecil as relatively impartial in comparison to Walsingham, a new picture has begun to emerge recently, particularly in the work of Stephen Alford, of Cecil as a committed Protestant with every interest in suppressing Catholicism as thoroughly as possible. ${ }^{5}$ While this supports Edwards' criticism of Cecil as a cynical manipulator to a point, this thesis would argue that his argument is flawed because he fails to recognise the distinct possibility that Cecil himself actually believed in the reality of these conspiracies. Rather than a cunning manipulator and fabricator of lies, Cecil was a justifiably paranoid man, who realised exactly how tenuous his Queen's grip on power was.

In a recent article, Peter Lake argued that not only did Cecil believe in an international Catholic conspiracy to destroy England, but this belief so distorted his world-view that he saw discrete events as part of a giant tapestry of plots and counter-

\footnotetext{
${ }^{3}$ Edwards, Plots and Plotters, p. 21.

4 ibid., pp.21-22.

5 Alford; Patrick Collinson, 'Pulling the Strings: Religion and Politics in the Progress of 1578,' in Jayne Archer, Elizabeth Goldring, and Sarah Knight (eds), The Progresses, Pageants, and Entertainments of Queen Elizabeth I, Oxford, 2007, pp.124-125, 134-136.
} 
plots. ${ }^{6}$ Applying Lake's thesis to the Ridolfi plot allows us to see Cecil's actions less as manufacturing a plot, and more as uncovering a series of events which Elizabethans saw as dialectically connected in a way that a modern reader cannot. ${ }^{7}$ The concept of a vast Catholic conspiracy to overthrow England's current regime was closely tied into the sixteenth century world view of politics as an essentially moral encounter between good and evil. As those who held authority did so by divine grace those who stood against them were consequently enemies of God's natural order seeking nothing but discord. ${ }^{8}$

Who the enemies of order were was uncertain during Elizabeth's reign, as the Queen tended to deal severely with extreme Protestants and Catholics alike. ${ }^{9}$ AntiPuritanism and anti-Catholicism were used by the Queen's councillors and courtiers trying to push her into acting against rival religious groups. In the mid-1570s, for example, Bishop Aylmer of London and the swiftly rising Sir Christopher Hatton rode a wave of anti-Puritanism to power, with Hatton following in Leicester's footsteps by making the transition from Queen's favourite to serious councillor. ${ }^{10}$ At the time of the Ridolfi plot, however, anti-Catholicism was on the rise, and the Privy Council was dominated by what Patrick Collinson describes as the 'hotter sort of Protestants."

If Cecil truly believed that Catholic plots were symptomatic of a wider conspiracy, it raises the question of whether William Herle believed in this scheme, or was merely facilitating Cecil's anti-Catholic fears to further his own personal and political advancement. Breight has argued that Herle was 'particularly adept at

\footnotetext{
${ }^{6}$ Peter Lake, 'A Tale of Two Episcopal Surveys: The Strange Fates of Edmund Grindal and Cuthbert Mayne Revisited,' Transactions of the Royal Historical Society, Sixth Series, No.18, 2008, pp.129-163; The idea of Cecil believing in an international Catholic conspiracy has been best articulated by John Guy: John Guy, 'Imagining and Detecting Conspiracy, 1571-1605,' http://www.tudors.org/public-lectures/77imagining-and-detecting-conspiracy-1571-1605.html, accessed 11 May 2010.

${ }^{7}$ Lake, p.135; A similar point about Elizabethans' propensity towards seeing conspiracies everywhere was made twenty years earlier: Lacey Baldwin Smith, Treason in Tudor England: Politics and Paranoia, Princeton (N.J.), 1986, p.125.

${ }^{8}$ Baldwin Smith, p.59.

${ }^{9}$ Lake, p. 135.

10 ibid.

11 Patrick Collinson, 'The Politics of Religion and the Religion of Politics in Elizabethan England,' Historical Research, Vol.82, no.215, February, 2009, p.80.
} 
encouraging ministerial paranoia,' citing his letters to Leicester and Cecil about those who slandered them. ${ }^{12}$ It is difficult to judge if Herle modified his level of antiCatholicism to cater to the privy councillors' fears, as all our surviving evidence is in the form of epistles from Herle to various ministers and officials, leaving us with no baseline for comparison. The most we can say with certainty is that Herle's letters exhibit similar fears of Catholic conspiracies to Cecil's writing.

\section{Cecil, Norfolk, and the Catholic Threat}

Cecil's response to the Ridolfi plot can only be understood in the context of the wider pattern he identified. This pattern was that of a great conspiracy being masterminded against England by the Pope, the Spanish king Philip II, and a variety of English peers, with the Ridolfi plot as the most important link in this chain of events. It was used by Cecil as part of a carefully constructed campaign against Norfolk, designed to topple him from his position as premier peer of the realm. The success of Cecil's attack on Norfolk indicates that he had judged his ability to manipulate Elizabeth correctly, while Norfolk and his supporters had foolishly relied on the Duke's position to protect him.

The first event Cecil identified in this conspiracy was the foreign policy crisis of 1568 known as the Spanish pay-ships controversy, an event that threatened to unseat Cecil from his privileged position and plunge England into war with Habsburg Spain. The détente between Spain and England almost evaporated in November 1568 when five Spanish ships, carrying bullion to pay Philip's troops in the Low Countries, took shelter in English ports from the storms of the Channel. Seizing the opportunity offered, Cecil ordered the gold unloaded - purportedly as a precaution against theft. ${ }^{13}$ The gold

\footnotetext{
${ }^{12}$ Breight, p. 106.

${ }^{13}$ Susan Doran, Elizabeth I and Foreign Policy, 1558-1603, London, 2000, p.13.
} 
was a loan from Genoese bankers and was technically still in their possession, meaning the English were not so much stealing Spanish gold as appropriating the loan.

Unfortunately for England, the newly arrived Spanish ambassador to London, Don Guerau de Spes, immediately wrote to the Duke of Alva demanding that English ships and property in the Netherlands be confiscated in reprisal. ${ }^{14}$ Elizabeth responded in kind and by early 1569 the lucrative trade between London and Antwerp had essentially halted. Facing potential economic disaster, a significant portion of the nobility turned on Cecil for his role in the debacle, in an attempt to oust him from his position. Elizabeth stood by her Secretary, and the action against Cecil crumbled. ${ }^{15}$

The majority of those who had turned on Cecil were part of a powerful aristocratic and semi-Catholic lobby at court, including the Duke of Norfolk, the Earls of Arundel and Pembroke, and Lord Lumley. ${ }^{16}$ These peers were loosely allied with certain members of the Northern nobility, primarily the Earls of Westmorland and Northumberland, and Lord Dacre. Both groups hoped to rescue Mary Stuart's fortunes by marrying her to Norfolk. ${ }^{17}$ Leicester was also involved in the plan, although he proved its undoing. Elizabeth's unequivocal support of Cecil during the pay-ships fiasco convinced Leicester that there was little point in continuing to undermine him, and he revealed Norfolk's intentions to Elizabeth, preserving himself while ruining the Duke. Norfolk was placed in the Tower, while Arundel, Lumley, and Pembroke were confined to their lodgings. ${ }^{18}$ Hoping to ensnare Mary, Cecil ordered her belongings to be searched, but no damning evidence was found. In a move typical of Cecil, he quickly

\footnotetext{
${ }^{14}$ Geoffrey Parker, The Grand Strategy of Philip II, New Haven (Conn.), 1998, p. 155.

${ }^{15}$ Neville Williams, Thomas Howard, Fourth Duke of Norfolk, London, 1964, p. 155.

${ }^{16}$ John Warren, Elizabeth I: Religion and Foreign Affairs, 2nd ed., London, 2002, p.67.

${ }^{17}$ Christopher Haigh, Elizabeth I, 2nd ed., Harlow, 2001, p.53.

${ }^{18}$ Alford, pp.158-159.
} 
ensured the situation was turned to his advantage by the means of a pamphlet, attributed to the zealous Protestant Thomas Norton but filled with Cecilian logic and rhetoric. ${ }^{19}$

The Ridolfi plot was the next part of the puzzle to come to light. Through a series of investigations and interrogations masterminded by Cecil, Herle extracted enough damning evidence from one of the conspirators to implicate a number of prominent Englishmen in treasonous activities. An Italian banker named Roberto Ridolfi had orchestrated a plan to instigate another rebellion against the Queen, this time with Norfolk and Mary Stuart at its head, and the Spanish Duke of Alva's troops backing the rebels. Caught secretly communicating with Ross and Mary, and turned in by his own secretary William Barker for sending $£ 600$ in gold north to foment rebellion, Norfolk had foolishly placed himself in Cecil's hands.

Imprisoned in the Tower on September 6 1571, Norfolk denied all association with Ridolfi's plot. ${ }^{20}$ Unfortunately for the Duke, Cecil was convinced of his guilt, and determined to persuade Elizabeth of it. In mid-October Cecil began a propaganda campaign designed to blacken Norfolk's name. The campaign started with an anonymous pamphlet, Salutem in Christo (1571), which claimed the Duke had continued to plot with Mary and Catholic figures. ${ }^{21}$ The pamphlet was printed by one of Cecil's favourite printers, John Day, and it is almost certain that Cecil composed it himself. In early January of 1572 Cecil produced another anonymous pamphlet, The Copie of a Letter (1572), which denounced both Mary and Norfolk. ${ }^{22}$ Cecil succeeded in turning public opinion against the Duke and by the time of his trial for treason on 16 January 1572 there was little doubt left as to the outcome.

\footnotetext{
19 Thomas Norton, A Discourse Touching the Pretended Match Betwene the Duke of Norfolke and the Queene of Scottes, London: Printed by John Day, 1569, STC 13869.

${ }^{20}$ Thomas Howard to the Privy Council, 22 September 1571, William Murdin (ed.), A Collection of State Papers, Transcribed from Original letters and Other Authentick Memorials, Left by William Cecill Lord Burghley, Vol.2, No.111.

${ }^{21}$ R.G. (likely William Cecil), Salutem in Christo, London: Printed by John Day, 1571, STC 11504.

22 Anon. (likely William Cecil), The Copie of a Letter Written by One in London to his Frend Concernyng the Credit of the Late Published Detection of the Doynges of the Ladie Marie of Scotland, London: Printed by John Day, 1572, STC 17565.
} 
To Cecil's dismay Elizabeth stayed Norfolk's execution, and he was forced to wait until Parliament was called in the late spring of 1572 in order to force the Queen's hand. Cecil and his Protestant allies pushed for Norfolk's execution and Mary's formal exclusion from the succession. ${ }^{23}$ In the end, Elizabeth sacrificed the Duke to quiet the House in the face of her defence of Mary. On the morning of 2 June 1572, Norfolk was beheaded on Tower Hill. Cecil was triumphant.

The Ridolfi plot, then, was a crucial turning point in Cecil's struggle with Thomas Howard. Even a man as powerful and politically astute as Cecil could not bring down the scion of one of England's oldest surviving families easily, and it was almost four years from the moment when Norfolk undermined Cecil during the pay-ships controversy until Cecil had his revenge. The Ridolfi plot was central to Norfolk's downfall from premier peer of the realm to executed traitor. Mary's involvement effectively eliminated any remaining chance of her taking the throne upon Elizabeth's death.

As Cecil's official narrative of the Ridolfi plot was written after events had already occurred, when he was trying to ensure Norfolk's execution, it is only through the study of contemporary letters that the gradual coalescence of its disparate parts can be seen. ${ }^{24}$ Herle's letters provide the most detailed available account of the Ridolfi plot. The other figures involved in the plot left no accounts, apart from confessions covered in Cecil's marginal notes, and in at least one case written at his direction. Herle's letters then, provide valuable detail and colour which Cecil's concise narrative cannot hope to match.

Herle's Ridolfi letters, while detailed, have gaps in their narrative. Herle met with Cecil on multiple occasions to discuss 'sondry things [he had] to say unto you by

\footnotetext{
${ }^{23}$ Alford, pp.192-195.

${ }^{24}$ Cecil's version of events is covered in the State Papers: William Cecil, 17 January 1572, TNA SP $12 / 85$, ff.35-38v.
} 
mowth,' a clear indication that Herle withheld his most pertinent information for these face-to-face meetings. ${ }^{25}$ Whether he did so to avoid discovery, or in the belief that delivering information in person would make a better impression upon Cecil, is difficult to say. Further, while Herle's letters survive, Cecil's replies do not. Cecil, it seems, was not entirely comfortable with his peers knowing of his association with Herle's nefarious activities, and preferred to state his case through official channels and pamphlets.

\section{William Herle in the Ridolfi Plot}

The story of the Ridolfi plot begins a month before Herle became involved, when an Italian banker named Roberto Ridolfi was arrested by Walsingham at Cecil's command. Born in 1531, Ridolfi had exploited his family's noble connections to become a nuncio segreto, or informal papal ambassador. His family interests brought him to England in the early 1560s, and by 1569 he was suspected of cultivating connections with Catholic rebels. Based on these facts, Walsingham confined the banker at his home in London where he threatened Ridolfi with imprisonment and torture in the Tower. ${ }^{26}$ Oddly, Walsingham did not charge Ridolfi with any crime and, in March 1571, allowed him to leave England with his bags unexamined. Carrying letters from his various English contacts, Ridolfi set off to meet Catholic leaders in Europe. $^{27}$ Between March and July, he visited the Duke of Alva, governor of the Spanish Netherlands, the Pope, and Philip II.

Ridolfi detailed a plan, debated vigorously by the Spanish Council in July, involving a rather optimistic three-part attack on England consisting of assassination, domestic rebellion and foreign invasion. Elizabeth would be captured or killed while on her annual Progress through the Home Counties. This would spark a general rising of

\footnotetext{
${ }^{25}$ Herle to Cecil, 4 April 1571, BL Cotton Caligula C III, f.60r; Herle repeats the need to convey information in person later that month: Herle to Cecil, 29 April 1571, TNA SP 53/6/53, f.89v.

${ }^{26}$ Edwards, The Marvellous Chance, pp. 29-30.

${ }^{27}$ Parker, The Grand Strategy of Philip II, p.130.
} 
English Catholics, led by Norfolk and Mary, reinforced by Alva's troops, transported from the Netherlands by a Spanish flotilla standing by at Santander. ${ }^{28}$ Mary would be crowned queen, returning England to the Catholic Church and making it a Spanish dependency resembling the Netherlands. The familiar elements of the plan did not make it any more workable, though it must be remembered that Philip delighted in overly detailed tactics requiring precise timing that often failed in execution, the Gran Armada of 1588 being a perfect example. ${ }^{29}$

While Ridolfi discussed the invasion plan in Brussels with Alva, he met with Charles Bailly. Born in Brussels, Bailly entered Mary Stuart's service in the mid-1560s. After Mary's confinement in 1568, Bailly acted as sometimes secretary and messenger for Ross. ${ }^{30}$ In early 1571 the Bishop engaged Bailly to travel to the Low Countries to arrange for the printing and importation of books responding to a government attack on the possibility of a marriage between Norfolk and Mary. ${ }^{31}$ The ideas contained within these books were a serious threat to Elizabeth, as they supported Mary's title to the Crown of England, and attacked the Protestants who had ousted Mary from her Scottish throne. ${ }^{32}$ Bailly failed to gain a license for printing, as Alva was wary of overtly supporting pretenders to Elizabeth's throne while she lived. Before he returned to England, however, Bailly met with Ridolfi, and agreed to carry letters across the

\footnotetext{
${ }^{28}$ Consulta of the Spanish Council of State, 7 July 1571, Archivo General de Simancas Estado 823/150158; and Philip II to Alva, 14 July 1571, Archivo de la Casa de los Duques de Alba 7/58; both cited in Parker, The Grand Strategy of Philip II, pp.130-131.

${ }^{29}$ Parker, The Grand Strategy of Philip II, p.131.

${ }^{30}$ Herle to Cecil, 19 April 1571, BL Cotton Caligula C III, f.178r; Bailly's confession to Cecil states that he has been a servant of Mary and Ross for seven years (since ca.1564); Bailly to Cecil, 2 May 1571, Murdin (ed).

${ }^{31}$ Bailly to Cecil, 5 May 1571, Murdin (ed.); the government tract is often attributed to Sir Francis Walsingham: Norton, A Discourse Touching the Pretended Match.

${ }^{32}$ Herle later described two of the books Bailly carried, both already well known in England and penned by the Bishop of Ross. Due to the use of 'good arguments, grett reson and plenty of our Comune Lawes,' Herle believed the Bishop could not have written it alone. This comment of Herle's seems odd, given that the Bishop had studied canon and civil law at Potiers, as well as serving as a judge of the Court of Sessions and on the Scottish Privy Council. Presumably Herle assumed that Ross had not bothered to familiarise himself with English common law. A legal-based argument would certainly not have been outside of Ross' abilities; BL Cotton Caligula C III, f.178r.
} 
channel for him. These letters were 'directed to two lords of this realm, advertising... his [Ridolfi's] safe arrival' from England, and his subsequent meeting with Alva. ${ }^{33}$

The authorities searched Bailly's bags upon his arrival at Dover on 12 April, discovering both the unbound book manuscripts and letters. ${ }^{34}$ Bailly was sent to William Brooke, Lord Cobham and Warden of the Cinque Ports, who interrogated him at his house in Blackfriars. ${ }^{35}$ Herle referred to this event in a letter to Cecil, where he mentions Bailly as having brought 'over nowe sondry writings which be dangerous as I heare and intercepted by the Lord Cobham. ${ }^{36}$ Herle's identification of Cobham, and his brother Thomas who was later charged with treason, as being associated with Ross at this point is particularly significant. According to Cobham's later declaration, taken by Cecil in October 1571, he was convinced by his brother to secretly forward the letters to Ross while passing the books on to Cecil. Cobham took the letters to Ross who was unable to decipher them. ${ }^{37}$ By noting this information, and passing it on to Cecil, Herle revealed the Cobhams' treachery at an early stage, even though Cecil chose to stay his hand for six months. Further, this early warning likely contributed to the Council's issuing of a warrant for Bailly to be held in the Marshalsea. ${ }^{38}$

\section{Herle and Bailly}

In early April 1571 Herle was ensconced in the Marshalsea prison. While his previous stint in this jail had been for piracy, Herle was now there to extract information about the Ridolfi plot from Bailly. Cecil and Herle obviously knew of Bailly's arrival at Dover before he was apprehended, as two days before the arrest Herle had asked Cecil

\footnotetext{
${ }^{33}$ Bailly to Cecil, 2 May 1571, Murdin (ed.).

${ }^{34}$ TNA SP 12/85, f.35; This date conflicts with that given in Herle's letter of 10 April, where he informs Cecil that Bailly was committed to the Marshalsea the night before. Although this undated letter is generally attributed to the tenth, its contents seem out of sync with the letters other Herle writes on the tenth and eleventh, and it entirely possible that it actually belongs later in the sequence of events, most likely on the thirteenth; Herle to Cecil, 10 April 1571, TNA SP 53/6/36, f.62r.

${ }^{35}$ Brooke to Cecil, 13 October 1571, TNA SP 12/81, f.117.

${ }^{36}$ Herle to Cecil, 11 April 1571, BL Cotton Caligula C III, ff.61r-61v.

37 TNA SP 12/81, ff.117-118v.

${ }^{38}$ BL Cotton Caligula C III, ff.178r-178v.
} 
to hold Bailly in solitary confinement upon his imprisonment. Herle claimed that if this was done the 'whole masses of their secretts' he knows could be ferreted out. ${ }^{39}$ The next day, Herle asked Cecil for 'some secret token' to show the warden, so that he could have access to Bailly once he was imprisoned. He expected little trouble ferreting out any secret Bailly may be hiding as 'he is fearefull, full of words, glorious, and given to the cup. ${ }^{40}$

Ross took Bailly's imprisonment 'verey displesantly,' particularly as the Spanish Ambassador's secretary had been with Bailly when he was apprehended. ${ }^{41}$ The Bishop feared this fact 'might brede grett suspicyon' 'of som privy juggling bettwen' Ross and the Ambassador, as 'allredy their familiarity was vehemently noted' by others. ${ }^{42}$ At this point, Ross clearly believed that Cecil did not know about the letters Lord Cobham had brought him for, as far as he knew, Cecil was only holding Bailly for the importation of illegal books. Herle was a natural plant for Cecil, with his previous record of imprisonment, and when the Bishop of Ross inquired around town about Herle, he found that the general opinion was that he was a 'discontented man and factyows. ${ }^{43}$ There was little, then, to rouse suspicions about Herle, and he was able to extract information from Bailly and Ross, implicating both with little difficulty.

With Bailly incarcerated and unable to contact his friends on the outside, Herle became a significant player in the story of the Ridolfi plot's collapse. Shortly after Bailly's arrival at the Marshalsea the warden had placed him in isolation, a tactic which Herle applauded, telling Cecil that many of Bailly's friends had visited him before the order was issued, and that now they were denied access Herle could step in as the prisoner's confidante. Already William Barthlett, one of the friends Herle mentioned,

\footnotetext{
${ }^{39}$ TNA SP 53/6/36, f.62r.

${ }^{40}$ Herle to Cecil, 16 April 1571, BL Cotton Caligula C III, f.61v.

${ }^{41}$ BL Cotton Caligula C III, f.179v.

42 ibid.

${ }^{43}$ TNA SP 53/6/53, f.89v.
} 
had come to Herle bemoaning Bailly's isolation. Herle offered to convey messages between Bailly and the Bishop of Ross, a proposal which Barthlett quickly accepted. ${ }^{44}$

Over the following weeks Herle met regularly with Bailly, stealing up to the window of his cell to take the enciphered letters Bailly wrote to the Bishop and pass them on, after Cecil copied them. During these visits, he pretended to be 'in grett fere to be surprised [caught] there, hazarding mi life as it were for his comfort and ayd,' all the while encouraging Bailly's fears to 'work hym the more. ${ }^{45}$ While Herle tried to draw the 'masses of their secretts' from Bailly by false friendship, Cecil made similar efforts through torture, threatening Bailly with the rack. Cecil later proved willing to rack Bailly within an inch of his life to extract a confession. Meanwhile, Herle worked to implicate others in Ross' entourage. Two of Bailly's friends, Mattinson and Melchior, visited on 18 April and were immediately imprisoned by the warden. ${ }^{46}$ Much as he did with Bailly, Herle encouraged Mattinson to spout treasonous declarations, marvelling that Mary was still imprisoned when she had so many influential friends and her delivery always seemed imminent. Deploring Elizabeth's treatment of the Scots, Mattinson bemoaned the catalogue of broken promises which accompanied England's abuses. ${ }^{47}$ Herle also made contact with the Spanish ambassador's secretary, but found him more circumspect than Bailly and his friends.

On 24 April, Herle made a drastic error which almost ruined his chances of extracting any further information from Bailly. Following Cecil's example, Herle subjected Bailly to a cross-examination 'in the B[ishop]'s name,' asking him if he had confessed that John Hamilton gave him the letters. ${ }^{48}$ At this point, Herle made a crucial

\footnotetext{
${ }^{44}$ Herle to Cecil, 16 April 1571, BL Cotton Caligula C III, f.61v-62r.

${ }^{45}$ Herle to Cecil, 18 April 1571, BL Cotton Caligula III, f.176v.

${ }^{46}$ Writing to Ross, Bailly told him that the two men had 'don very yll to com hither, having bene warnyd of that that is happenid unto them'; Bailly to Leslie, 20 April 1571, Murdin (ed.).

${ }^{47}$ BL Cotton Caligula C III, ff.178v-179r.

${ }^{48}$ Herle to Cecil, 24 April 1571, TNA SP 53/6/48, f.82r.
} 
slip, asking Bailly 'whither his examinatyon extended not to know whatt delyng he had with the English rebelles.' This last phrase shocked Bailly:

He was so astonyed, as albeit though there were no light, his allteracion was apparent \& falling he fell into a sodein trembling \& to suche a faltryng of his tong, as in som whyle he cowd expresse nothyng well, butt in th'end he axed, whye then hath nott mi Lord his $1[\mathrm{ett}] \mathrm{res} ?^{49}$

Herle recovered from this blunder by telling Bailly that the Bishop had indeed received the letters, but had asked him to question Bailly before he was able to decipher them so would not have the benefit of the information contained therein. Bailly seemed to believe him, and stammered that he had 'confessed nothyng of Hamilton' and detested the rebels, 'using suche vehement passion in speking of them, as though they had byn fellowes to the devyll. ${ }^{50} \mathrm{He}$ also told Herle that Cecil had 'threttned hym dethe or att lest wise the losse of his eres.'

Herle realised that he was pushing too hard and backed off, 'reconcileng hym with more plawsible \& sweter matter' before he left. ${ }^{51}$ The next morning, Herle hid in the privy in the garden and gave Bailly the letter from the Bishop. Bailly was delighted and promised a response that afternoon. On his way out Herle was reproved by Bailly's guard who saw him leaving the privy. That afternoon, he went to an alley near Bailly's cell and received Bailly's answer through the grate, quickly sending it on to Cecil. A baker's wife spotted him lurking round the alley, told him 'ytt cowd be no honest matter that I [Herle] offred in so unffytt a place,' and threatened to report him to the Keeper. Herle fled, rounding out a less than impressive day.

Herle's plan to extricate information from Bailly and secure Cecil's continued favour seemed close to collapsing completely. On 24 April, Bailly communicated his fear that Herle may be a plant to the Bishop. ${ }^{52}$ It seems a mysterious Catholic priest

\footnotetext{
${ }^{49}$ ibid.

${ }^{50}$ ibid.

${ }^{51}$ ibid.

${ }^{52}$ Bailly to Leslie, 24 April 1571, Murdin (ed.).
} 
warned Bailly that he should not put too much trust in Herle. ${ }^{53}$ Bailly asked Ross if he had received his earlier letter proposing an alternative means of communication, whereby letters would be passed through the small window in his cell to an adjoining alleyway, so that Herle could be bypassed.

By 26 April, Herle had told Ross that he had been put in close confinement for association with Bailly. The problem of how he could send and receive letters while Bailly, ostensibly in the same conditions of imprisonment, could not was explained away by Herle being held on the 'street side' of the prison, where his man could deliver letters and writing materials to him. ${ }^{54}$ Herle attempted to deflect any suspicions the Bishop may have had about him by posing as a fellow suspect, claiming he had been examined by the Council and threatened with the rack. ${ }^{55}$ Unfortunately for Herle, this explanation does not seem to have allayed the Bishop's suspicions, as his reply the next day was decidedly guarded. ${ }^{56}$ Yet letters continued to flow. Having no other contact with Bailly, the Bishop needed Herle, even if he was a decidedly suspect courier.

Ross had heard that Herle had 'beene before the Councell and Charles [Bailly] face to face,' and desperately needed to know 'what you have said to him or he to you in their presence. ${ }^{57}$ Presumably Ross feared Cecil may have established some link between Bailly's actions and those of his master. While the Bishop's next letter to Herle does not survive, we can glean some of its contents from Herle's reply. Herle wrote that he was shocked by the Bishop's lack of trust in him, and saw himself as being 'bettwen the hard Annevylld and the hamer,' yet hoped to reassure Ross that there was nothing untoward going on. ${ }^{58} \mathrm{He}$ attempted to further alleviate the Bishop's fears by telling him

\footnotetext{
53 There is no mention of this priest elsewhere.

${ }^{54}$ Herle to Leslie, 26 April 1571, BL Cotton Caligula C III, f.65r; Herle covered much of the same information in two letters to Cecil on the same day: Herle to Cecil, 26 April 1571, BL Cotton Caligula C III, f.239r; Herle to Cecil, 26 April 1571, BL Cotton Caligula C III, ff.68r-68v.

${ }^{55}$ BL Cotton Caligula C III, f.65r.

${ }^{56}$ Leslie to Herle, 27 April 1571, BL Cotton Caligula C III, f.70r.

57 ibid.

${ }^{58}$ Herle to Leslie, 28 April 1571, TNA SP 53/6/52, f.88r.
} 
that 'the Cowncell stormes that Charles [Bailly] will utter nothing.' Unfortunately for Ross, this was not the case. Bailly soon confessed and the Bishop was placed under house arrest. While Cecil continued to investigate the Ridolfi plot, and use it as ammunition for his attack on Norfolk, Herle's part in the process was done.

\section{Outcomes of the Ridolfi Plot}

The Ridolfi plot had significant consequences for the future of Catholicism within England. The threat of internal Catholic dissent seemed much diminished in the wake of the plot's discovery and failure. While closet Catholicism still remained a concern to the government, it was increasingly obvious that few, if any, Englishmen were willing to risk death or exile by overt action on behalf of Catholicism. Ross and Mary's involvement in the plot tarnished the Queen of Scots' image to the point where she posed little immediate threat, and the downfall of Norfolk, Northumberland, and Westmorland quietened those magnates who had posed such a threat to the Crown's power in the late medieval period. ${ }^{59}$

The plot also altered English foreign relations, moving Elizabeth towards a closer relationship with France, England's traditional enemy, at the expense of her relationship with Spain. The Spanish ambassador's peripheral involvement in the Ridolfi plot, combined with news of the Spanish naval victory at the battle of Lepanto which reached England in early November 1571, raised alarms that Philip, apparently freed from the Turkish threat in the Mediterranean, might mobilise his resources against England. Foreign policy in the aftermath of the plot was largely concerned with Elizabeth's proposed marriage to the French Duke of Anjou. The “Anjou Match" served to hold Philip at bay, with the constant threat of a marriage alliance between France and England putting his hold on the Spanish Netherlands at risk.

\footnotetext{
${ }^{59}$ MacCaffrey, Queen Elizabeth and the Making of Policy, p 25.
} 
Herle's involvement in the plot had a significant impact on his life, even after his part in it was finished. The most obvious benefit it had for him was that it brought him closer to William Cecil. Norfolk's elimination, combined with Leicester's decision to side with Cecil, put the Secretary in an almost unassailable position of power. Herle benefitted commensurately from his patron's increased access to power and influence. Of more immediate aid to the interminably indebted Herle, Cecil seems to have paid well for his services. In his final report on the Ridolfi plot, Herle admitted that Cecil had been generous thus far, sending him a total of $£ 11$ to cover various expenses. ${ }^{60}$ Finally, he asked the Secretary to commend him to the Bishop of Salisbury and 'the Master Comptroller [of the Tower],' an indication that his rewards for service were social as well as pecuniary. ${ }^{61}$

\section{Further Intelligence Work}

Gaining Cecil's approval through his work on the Ridolfi plot also helped Herle in gaining continued government employment. Herle clearly felt Cecil favoured him at this point, as he applied for a number of positions. In October 1571 he wrote to Cecil asking for his support in securing a position to 'survey strangers,' a euphemism for the hunting of 'Papistes, Anabaptistes, Libertynes, dronckards, Comune women, \& Brothell howses. Allso espyalles, murtherers, theves, \& Conspirators. ${ }^{62}$ Herle's petition failed, and he wrote to Cecil again in January 1572, asking that the Secretary petition Elizabeth on his behalf for the 'reversyon of the gentillman porters office in the Towre. ${ }^{93}$ This time it seems he was successful in his petition, as a letter from a counterfeiter named Edward Phaer mentions Herle in this context. Phaer wrote to Cecil in December 1577, confessing to counterfeiting coins and saying that 'it pleased M[aster] Lieutenant and

\footnotetext{
${ }^{60}$ Herle to Cecil, 1 May 1571, BL Cotton Caligula C III, f.72r.

61 ibid., f.72v.

${ }^{62}$ Herle to Cecil, 3 October 1571, TNA SP 12/81/34, f.97r.

${ }^{63}$ BL MS Lansdowne 16, f.80v; Herle was not immediately successful, as he asked for the same post in a letter two months later; Herle to Cecil, 16 March 1572, BL, MS Lansdowne 16, ff.102v-103r.
} 
M[aster] Herle' to confirm this. ${ }^{64}$ Similarly, a letter from Cecil to Herle in August 1573 described him as having received a 'sute of som good valew' from Elizabeth, the timing of which would indicate it was likely this post. ${ }^{65}$

A pair of letters from the early 1570 s also show that Herle and Cecil's patronclient relationship had evolved in the aftermath of the Ridolfi plot. In a November 1571 letter to Cecil, Herle detailed the activities of John Horneby and 'Dawbney.' These men had been caught burning a book which Cecil wished to get hold of, and now hoped that Cecil would accept their apologies. ${ }^{66}$ Herle appears to have been acting as an intermediary between Horneby and Cecil, an indication that he was confident in his ties to the Secretary. Nowhere else, with the exception of his support of Paul Buys' Dutch delegation, did Herle really act as a channel for Cecil's patronage. Usually Herle was at the bottom of the patronage ladder, but for this short period Herle felt confident enough in his position to use some of his precious time with Cecil to represent others' interests.

A fortnight later Herle detailed further information about Horneby's activities. Herle was trying to uncover fraud amongst customs officers, and was encouraging Horneby to inform on other officials. Desperate for release from prison, Horneby offered to 'declare suche matter as noman can do butt hym self, discovering grett frawds $\&$ those verey secret, which the customers \& officers have robbed the Q[ueen] majestie by. ${ }^{67}$ Dawbney was mentioned as one of these corrupt officials, alongside 'Mathewes,' 'an ignorant grosse fellow, a verey belly God \& comune dronckard.' The real mastermind of the scam, however, was 'Smith the Customer,' who had 'secrett metyngs in Saint Georges filds’ with Mathewes. Smith tried to bribe Horneby $£ 100$ to help cover up their doings 'lest your L[ordship] shold discover the gret disceytts \& infinite robryes

\footnotetext{
${ }^{64}$ Edward Phaer to Cecil, December 1577, BL MS Lansdowne 25, f.146r.

${ }^{65}$ Cecil to Herle, 10 August 1573, BL MS Lansdowne 21, f.31v.

${ }^{66}$ Herle to Cecil, 6 November 1571, TNA SP 12/83/6, ff.9r-10v.

${ }^{67}$ Herle to Cecil, 18 November 1571, TNA SP 12/83/12, f.32r.
} 
by this service. ${ }^{68}$ According to Horneby, Dawbney and Mathewes organised his imprisonment so that he could not inform on them.

The scam these customs officials were running was based around mispricing imported alcohol. Herle stated that 'the Customers did abuse the Q[ueen] grettly in matter of lycens, aswell of Bere as wyne. ${ }^{69}$ They granted licences for the transport of beer 'without ether subsedy or imposte,' allowing those who paid them for licences to import ' 17 or 1800 tone of bere yerely' while keeping it off the books and avoiding duties. Wine was noted being 'wynes of Navarra \& highe Contrey wynes' when it was really 'Gascoyn \& frenche wynes,' thus avoiding higher duties. ${ }^{70}$ Herle estimated that the Crown could make $£ 10,000$ a year if Cecil took the time to 'redresse it hereafter for the Q[ueen] majesties singuler benefyte.' The sums Herle alleges were being stolen were substantial, and it is impossible to imagine Cecil ignoring the possibility of increasing the Crown's income by such an amount.

Herle wrote no more of this potentially explosive scandal however, and it seems little came of it. As Horneby was in prison, he may have been spinning Herle a tale designed to lure Cecil into organising his release. While Herle was surely suspicious, he could hardly have passed up the chance to further ingratiate himself with Cecil. Sensitive information was the primary commodity Herle provided to his patron, and details of a widespread scam by customs officials were certainly that. His time in prison during the Ridolfi plot had clearly provided Herle with useful contacts, and he must have seen them as a potential cornucopia of intelligence to pass to the Secretary.

Herle continued to make intelligence reports to Cecil throughout 1572 . The influence his success with the Ridolfi plot had on the type of information Herle passed is obvious throughout this period, as he continued to focus on conspirators' activities.

\footnotetext{
${ }^{68}$ ibid.; In detailing this attempted bribe, Herle writes 'he offred to me on Cli by Horneby' $£ 100$, perhaps indicating that he had been targeted for a bribe by Smith as well. As Herle often struck mistakes through when writing to save paper, however, this is more likely to merely be an error on his part.

${ }^{69}$ ibid., f.32v.

${ }^{70}$ ibid., f.33r.
} 
Writing to Cecil in late February 1572, Herle detailed the danger posed by 'Maisonfleur.' This man had ties to the same players that Cecil had identified in the Ridolfi plot, as he was:

first being secretorye to the late duke of Gwise..., \& then to the scottish $\mathrm{Q}$ [ueen] that now is, all his affectyons ar to the sayd Q[ueen] \& to the howse of Gwise. $^{71}$

Having snuck into England 'pretending som matter here from the Duke of Alenson,' the Frenchman proceeded to have 'secrett conference with the Frenche ambassador' and now had 'at his devotyon bothe sowdyors \& desperate fellowes, redy to execute ani mischeeff' that he might require. Many of those he hired were formerly in Mary's employ, and Herle suspected that they intended 'som ille disposityon' as they and their mistress bore 'an ill mynde... to this state \& tyme.'

Herle gave Cecil further details of Maisonfleur's nefarious plan. The Frenchman had been bragging that the next day there would be 'suche an alteracyon here uppon the sodeyn, as never was sene. ${ }^{72}$ When this occurred, "those that be in prison shalbe delyverd, \& liberty shalbe turned into Captivitye; mene men shalbe raysed highe \& those that be highe abbused.' Herle then explained the meaning of these words to Cecil, somewhat unnecessarily one feels, 'that the Scottish Q[ueen] is ment for on partye, \& the Q[ueen] majestie our soveraigne for another.' The links to the Ridolfi plot are clear, and show how Herle attempted to recapture past successes. Much like Horneby's revelations of crimes by customs officials, there is no further evidence of this plot, an indication that Herle's intelligence was probably greatly inflated. This did not stop him making reports of further conspiracies he had discovered.

In March of the same year Herle wrote to Cecil, informing him that a number of men intended to travel to Spain and aid Sir Thomas Stucley in his invasion of Ireland. Stucley was a former soldier who spent most of his time at the Spanish and Papal

\footnotetext{
${ }^{71}$ Herle to Cecil, 26 February 1572, BL MS Lansdowne 16, f.98r.

72 ibid., f.98v.
} 
courts, attempting to persuade Philip and other Catholic leaders to invade England. ${ }^{73}$ There were rumours of such an enterprise's imminence throughout the $1570 \mathrm{~s}$, and it seems Herle was caught up in reporting one of these. The men he claimed were travelling to aid Stucley were 'Sir Warham Sentliger,' 'Jerom Brett,' 'Martin Furbisher,' 'Haselby a seaman \& John Poole mi frind.' ${ }^{74}$ Herle was extremely apologetic that Poole had been caught up in this madness, informing Cecil that ' $\mathrm{I}$ prefferre loyallty to ani friendship.'

In this letter we also gain a glimpse of Herle's own network of informants and the means by which he gathered information to pass to Cecil. Furbisher's wife was 'the discoverer of this pack,' and Herle warned Cecil that her willingness to inform on her husband was based "partly of displesure borne to Sir Warham Sentlyger as I perceve, \& partly of som jarre hapned bettwen Furbisher \& her. ${ }^{75}$ Nevertheless, said Herle, 'there is grett likelihood that every parte therof shold be true,' and through 'suche displesures, women mani tymes have disclosed grett treasons.' Herle recommended that Cecil send for her and hear her story for himself.

Nothing more was said of Furbisher's plans to travel to Spain, but the letter contained details of certain rewards Herle received for his part in the Ridolfi plot and his subsequent role as an information gatherer. Herle stated that he had been 'modestly attending whatt shold be disposed of me, than craving whatt becam me nott. ${ }^{, 76} \mathrm{He}$ admitted that the Queen had bestowed 'somes of money uppon me' for his service, but that the money had been used up paying off debts incurred during his imprisonment in the Marshalsea. Elizabeth had also granted Herle a 'lease in reversion,' giving him an income from property. In addition to these rewards, Cecil had granted Herle the

\footnotetext{
${ }^{73}$ Peter Holmes, 'Thomas Stucley (c.1520-1578),' ODNB, http://www.oxforddnb.com/view/article/ 26741, accessed 11 May 2010.

${ }^{74}$ BL MS Lansdowne 16, f.102r.

${ }^{75}$ ibid., f.102v.

76 ibid.
} 
'stallment of Richard Smiths detts,' presumably holding off Herle's most rapacious creditor.

By May 1572 Herle's financial situation had become truly dire. His creditors pursued him 'with a vexatyon worse than dethe it sellf,' and Herle wrote to Cecil again asking for help. ${ }^{77}$ Closely tied to his financial difficulties was the adverse effect on his social position that Herle's time in prison had caused. This is hardly surprising of course, as a gentleman would not generally expect to be clapped in irons and dragged off to the Marshalsea. He seems to have been particularly aggrieved by this loss of standing though, and complained that:

By mi late servyce [I have been] brought into suche a disdayne $\&$ hatred in the world, as besyde these thretts that I suffer daylye, sundry qwarrells ar made unto me, \& mi grettest frynds vowchesave nott to loke uppon me.

Between the loss of his friends and his lack of funds, Herle felt he was far worse off now than before he entered into the Queen's service. He lamented that he was shunned by all, despite the fact that he was 'nott in ani danger nor extremitye butt for her [Elizabeth's] sake, \& for the zele I have to her safety.'

This loss of status and money led Herle to give the impression that government service had ruined him. In addition to complaining about debts and loss of status, Herle noted that imprisonment cost him investment opportunities. In the margins of the letter bemoaning his hard state, Herle claimed that:

mi frynds the laste yere whles I was in the towre that wold have given me a $[£ 100]$ in cattell in wales, will nott now upon this mi generall disgrace give me a peny. besyde other expencs \& losses sustayned therby. ${ }^{78}$

Herle's list of losses he had sustained through government service was substantial. It is of course possible that this letter was merely an attempt to get money out of Cecil to pay

\footnotetext{
77 TNA SP 12/86/36, f.165r.

78 ibid., f.166r.
} 
off his debts. Given Herle's continued service in the Secretary's employ, despite claims that it was ruining him, this seems a likely alternative.

In the first half of the sixteenth century, France and the Habsburg Empire were the dominant powers of Europe. Yet by the late 1570s the French monarchy had been weakened by a series of civil wars between the ultra-Catholic house of Guise, often backed by the Crown, and the Protestant Huguenots, represented at a national level by the princes of Condé and Navarre. ${ }^{79}$ On 24 August 1572, the French king Charles IX ordered the massacre of thousands of Huguenots, shocking Protestants all across Europe and inciting fear of further Catholic atrocities. Herle responded to this event in characteristic fashion, by informing Cecil of the doings of one 'Mowlyns..., an englishman verey stowtt in Papistry...[and] cam owtt of frawnce of late. ${ }^{, 80}$ Mowlyns and his associates were 'resortyng verey familyerly to the frenche ambassador,' linking them to the government which had recently ordered the execution of its own Protestant citizens. By specifically tying this report of Catholic insurgency in England to France, Herle showed his ability to identify pertinent threats to English security and adjust what information he funnelled to Cecil to best exploit the fears of Privy Councillors.

Two days after this first letter, on 30 September 1572, Herle wrote to Cecil again, increasing the complexity of this purported Catholic plot by speculating that 'the frenche king wold verey shortly joyne in open maner with the king of Spaigne against the Q[ueen] majestie of England,' and 'wold be glad to fynde the lest qwarrel, wherby he might breke the leage with England, \& wold leve no occasyon unsought to provoke the same. ${ }^{81}$ Herle referred to the Treaty of Blois, an accord between England and France which had survived the shock of the St Bartholomew's Day Massacre, and which he now claimed France was subtly undermining in a dastardly Papacy-approved

\footnotetext{
${ }^{79}$ N. M. Sutherland, The Massacre of St Bartholomew and the European Conflict, 1559-1572, London, 1973, pp.3-5.

${ }^{80}$ Herle to Cecil, 28 September 1572, BL MS Lansdowne 15, f.180r.

${ }^{81}$ Herle to Cecil, 30 September 1572, BL MS Lansdowne 15, f.185r.
} 
plan to marry Mary Stuart to the Duke of Anjou, so joining England, Scotland, and France under Catholic rule. ${ }^{82}$ The vast conspiracy Herle outlines is remarkably similar to that which Cecil described during the Ridolfi plot and its aftermath, and this is unlikely to be a coincidence. Much as Herle's letter of the twenty-eighth evoked the Ridolfi Plot to catch Cecil's attention, this one regurgitated Cecil's own propaganda back at him. The focus on France over Spain as the primary instigator of Catholic aggression, however, was indicative of the mental shift which St Bartholomew's Day had inspired.

With the French monarch under the influence of the Catholic Guises, France no longer seemed the reduced threat it had been through the first decade of Elizabeth's rule. Cecil and the Queen moved to counter the potential alliance between Spain and France that Herle feared, by pacifying Spain. Cordial relations were restored via the Convention of Nijmegen in March 1573, and further formalised in the Treaty of Bristol in August 1574. While the Tudor-Habsburg relationship never again reached the level of amicability that it had enjoyed during Mary's reign, or even that before the pay-ship fiasco of 1568 , tensions were certainly relaxed to a significant degree. The issue which prevented further reconciliation was England's tacit support of the Netherlands rebels. Susan Doran has gone so far as to argue that if the revolt in Holland and Zealand had petered out in 1572, it is quite possible that Anglo-Spanish relations would have returned to their earlier footing. ${ }^{83}$ It was Spain's continued attempts to crush the rebellion, and England's tacit support of the rebels, which placed an intolerable strain on the traditional amity and ensured the Netherlands remained the main theatre of contention throughout this period.

\footnotetext{
82 ibid., f.185r-185v.

${ }^{83}$ Doran, Elizabeth I and Foreign Policy, p.34.
} 
William Herle's involvement in uncovering the Ridolfi plot was clearly a turning point in his life. Having begun the 1570s in disgrace for his alleged piracy, and with his career prospects dimmer than ever, Herle was able to turn his life around and carve out a new niche for himself in the Elizabethan government. This period is the part of Herle's life where he most often makes it into wider histories, and with good reason. The Ridolfi plot was one of the most significant non-events of Elizabeth's reign, with its discovery marking the execution of England's premier peer and Cecil's main rival at court. This chapter has argued that the Ridolfi plot must be understood as part of a series of conspiracies that Cecil saw as a coherent Catholic attack on the throne. Despite what historians such as Edwards have argued, this chain of conspiracies was not cynically crafted by Cecil but a genuine fear. Herle's many allusions to this conspiracy indicate that he knew Cecil believed in its veracity, and likely feared it himself. Norfolk's execution left Cecil unchallenged as the most powerful man in England, and Herle benefited from his patron's rise to primacy.

Herle's success in uncovering information about the plot led him to reinvent himself as primarily an intelligence gatherer rather than the financial negotiator he had been throughout the 1560s. While his career focus changed, Herle remained deeply in debt, the rewards he received for his intelligence gathering never outweighing his costs. Nor did he ever manage another intelligence coup of the Ridolfi plot's magnitude. Throughout the remainder of his life, however, Herle was able to combine his early experience in the Netherlands with his newly honed intelligence skills. 


\section{Chapter III: Contrasts in Patronage}

Understanding the Tudor patronage system affords an important insight into Tudor history, and Herle's letters provide an unusually detailed example of the system in operation. This chapter therefore develops a theme raised in the first chapter, Herle's patron-client relationship with William Cecil, to provide a detailed study of this often overlooked area in Tudor history. Herle's letters illuminate two starkly contrasting examples of patronage. In the aftermath of the Ridolfi plot Herle utilised his increasingly impressive patronage connections, enlisting Cecil's support for a lucrative marriage that would end his financial difficulties, and convincing both Cecil and Leicester to support him against his creditors, the Waad brothers. Herle's letters illustrate how even those of low social standing could leverage their connections to powerful patrons for beneficial outcomes.

Herle's letters also demonstrate that that leverage came from the client's immediate value to his patron. Herle's influence in the mid-1570s contrasts with a decade later, when his patrons declined to save him from ruin. This change reflected his deteriorating relationship with Cecil, and the diversification of his patronage base. Cecil's anger when Herle displayed his letters to other Privy Councillors fractured their relationship, from which Herle never truly recovered. Herle increasingly cultivated other patrons such as Leicester and Walsingham, gaining the support of other Privy Councillors, but reducing his value to Cecil. Sir Christopher Hatton's increasing influence, at the expense of Herle's Protestant patrons on the Privy Council, further contributed to Herle's misfortune. His inability to gain the Council's clerkship, despite Cecil and Leicester's support, demonstrates how closely the success of a client such as Herle was tied to that of his patrons'. 
Because the evidence about political patronage is sparse, the historiography of patronage is extremely limited. A number of historians have discussed the patronage of art, theatre, and economic or building projects, but few discuss political patronage. Simon Adams' collection of essays Leicester and the Court, and Pauline Croft's edited collection Patronage, Culture, and Power: The Early Cecils are exceptions, but eschew the details of patronage interactions in favour of broad thematic coverage. ${ }^{1}$ The primary reason for this historiographical neglect is that the vast majority of patron-client interactions occurred verbally in personal meetings. Herle's letters contain a wealth of information about patronage interactions and often record details of personal meetings. This makes them a rare, if not unique, resource for the study of Elizabethan patronage. This chapter utilises Herle's letters to demonstrate how his patron-client relationships changed and evolved over time.

\section{Herle's Marriage Prospects}

In August 1573 Cecil recommended Herle to 'ani wydow that he wolld make that superscriptyon unto.'2 Marriage to a rich widow could have ended Herle's financial difficulties, and Cecil likely provided the letter to end Herle's requests for money from his patron. Despite being addressed from Cecil to Herle, this letter is in Herle's hand, because it is a draft Herle made for Cecil's use. This explains why a letter seemingly from Cecil survived when the majority of their correspondence consists of Herle's letters directed to the Lord Treasurer.

The letter praises Herle extensively, and tries to convince the intended recipient that Cecil considered him a trusted client. As Herle's opinion of his value to Cecil, it is worth quoting from at length:

I understand that on master William Herlle a gentillman whom I have long knowen, $\&$ that is verey well borne, \& of a good kinred, dothe make

\footnotetext{
${ }^{1}$ Simon Adams, Leicester and the Court; Croft (ed.).

${ }^{2}$ BL MS Lansdowne 21, f.31v.
} 
menes to have your good will to becom your husbond, \& becawse I have good cawse to know hym \& to love hym, \& therfore I am desirows to do hym good, I am thus bolld to require you to credit me, that I thinck assuredly he will prove an honest husband \& will behave hym self towards you like a gentillman to be loved of you. ${ }^{3}$

Herle's letter to Cecil the following November suggests that Cecil had acquiesced to this description, for it recalls that Cecil had given him a letter 'towards ani wydowe where I wolld sue (though yett I never shewed it to ani),' and included a copy of it 'to remember yow therby of the goodnes that ye have used to me \& to desire humbly the contynuance therof. ${ }^{4}$ Unfortunately this copy has been lost.

Herle's draft not only stressed his good birth, Cecil's appreciation of his character, and his personal honesty, but the Queen's appreciation of his extensive abilities, which she would continue to reward:

$\mathrm{He}$ is surely a gentillman of verey good qwalityes, wise, lerned, \& of grett experyens in mani thynges, \& so hath bin employed in sondry services for the Q[ueen] majestie: in which respect he hath her majesties favor \& is well knowen of her, insomuche as now verey lately, her majestie hath granted to hym a sute of som good valew for his reward, \& is further to be considered by her majestie whan tyme may serve with som convenient office. ${ }^{5}$

All this would help to establish 'his better cowntenance mayntenaunce \& credite,' which would also reflect well on Cecil.

Herle's concern with maintaining and increasing his reputation at court was reiterated in August 1573, when Herle asked Cecil to help him overcome his mounting debts. Herle confidently assumed that Cecil would help him, 'knowing verey well that her majesties inclynatyon \& yowres is, to rayse me from these miseryes \& wants wherin I have bin, \& to make me hable to lyve competently in the world. ${ }^{6}$ While Herle claimed a status appropriate to them, they had in fact produced little money, so that 'mi creditors in the mene tyme supposing that I have even mowntaynes,' earned through crown service, 'do so importune me, as that I am wery to be in ani place.' Herle encouraged

\footnotetext{
${ }^{3}$ ibid.

${ }^{4}$ Herle to Cecil, 4 November 1573, BL MS Lansdowne 21, f.30r.

${ }^{5}$ BL MS Lansdowne 21, f.31v.

${ }^{6}$ Herle to Cecil, 21 August 1573, BL MS Lansdowne 15, f.171r.
} 
Cecil to help him out of this double bind by warning that though he was 'more redy to do ani servyce that lyes in me' his creditors 'give me no tyme to attend suche an occasion.'

Herle summarised the rewards the Queen had given him, and how they had been spent in her service. He asked Cecil to 'be the judge[,] for of [£200] that her majestie hath bestowed uppon me in money att iij severall tymes,' the majority had been spent on debts incurred in his work. ${ }^{7}$ Two-hundred marks (£130) went to his creditors who 'had most nede of it,' and a further $£ 50$ maintained him during his imprisonment to investigate the Ridolfi plot, leaving Herle less than $£ 20$ 'for me to lyve upon.' Herle noted that Cecil had helped earlier that year, when Elizabeth 'dyd by your honorable motyon grawnt me a lease in reversion.' But he was now 'content to resigne it agayn, \& beseche only to have som other thyng bestowed uppon me' in its place. This last point shows that Herle essentially rejected Elizabeth's gift because it had no resale value.

The 'other thyng' was the right to police the correct production of cloth. Herle had previously petitioned Cecil unsuccessfully for this office 'att Hampton Cowrte when her majestie this last sumer began her progresse. ${ }^{8}$ The lucrative office involved the 'surveyng of clothyers to make trew drapery' and, because of its opportunities to collect fees and bribes, attracted considerable politicking. Both Hatton and the Leicester had requested it for their clients, and to Herle's disgust Hatton's man had been granted the office. Herle now hoped that Cecil would speak with Leicester and offer his client, a clothier named Blackburn, a deal where Herle would 'have the Q[ueen] m[ajes]ties parte for my portyon \& the sayd Blackburne to have the other moytye [half].' This plan went counter to Elizabeth's decision, and was clearly against her interests.

Herle used several arguments to support his position. He claimed that many merchants agreed that the office should be reassigned. Otherwise, he argued, 'the

\footnotetext{
7 ibid., f.171r.

${ }^{8}$ ibid., ff. $171 \mathrm{v}-172 \mathrm{r}$.
} 
clothyers fallse drapery' would lead to both a 'generall losse att home' and 'a generall sclander abrode, which in th'end will overthrow the credite of our clothing throwowtt the world." Inevitably, Herle argued that if granted this office he would 'use suche modesty \& discretyon, as nether disorder shall follow.' The fact that Herle did not receive the office is less important than his claim to a gift which ran counter to Elizabeth's interests and would require Cecil to challenge the increasingly influential Hatton. This indicates that Herle believed he could exert substantial leverage over his patron.

When combined with his willingness to reject Elizabeth's previous gift, it shows that Herle's own estimation of his worth to Cecil was at a peak. Herle was obviously mistaken, as Cecil's refusal to spend some of his political capital to secure the position shows that he felt no need to make a concerted effort on his client's behalf. Furthermore, because he had failed to gain significant recompense for his crown service, Herle perforce had to continue working for Cecil and the Queen. Cecil could continue to manipulate Herle with the expectation of future relief from his debts, which shows that despite Herle's attempts to leverage Cecil's goodwill, the power in their relationship remained with Cecil.

In November 1573 Herle informed Cecil about the result of his recent journey to Wales. Herle had been part of a 'Comissyon of Conselements' with 'other of her majesties offycers,' which lacked sufficient time to gather evidence of concealed crown lands and return a verdict. ${ }^{10}$ However, he had been able to uncover land worth 'wellny [£133] by the yere, in that Cownty of Meryoneth, which wolld have com peceably to her majestie.' Herle predicted that he could gather 'a grett dele more in the other shires adjoyneng.' He planned to pass his commission to 'master Fanshawe' and asked to be

\footnotetext{
${ }^{9}$ ibid., f.172r.

${ }^{10}$ BL MS Lansdowne 21, f.29r.
} 
'employed in ani other thing,' which he 'wolld to mi power \& capacity faithfullye \& diligentlye discharge the same.'

This letter reveals how the patronage system rarely worked in Herle's favour, as well as the limits of Cecil's influence. Herle thanked the Lord Treasurer for asking Elizabeth to grant him 'the offyce of the wood wardship of the Cownty of Herryfford,' the official keeper of the Queen's forests in that shire. ${ }^{11}$ Cecil had stayed 'master Smithes' application for the office 'tyll ye moved her majestie to bestowe it uppon me.' Unfortunately for Herle 'the office was given to master Woodfford of the spycerye.' Despite his disappointment, Herle took care to thank Cecil 'for your goodnes to me, which is noles than if I had enjoyed it.' He also took care, however, to accuse Woodford of corruption, informing Cecil that:

Woodfford hath made suche a on his depute as was in hand to have bowght a wood which he termed a vallett wood nere unto his howse, \& now by this deputacyon, he hath gotten som part of his will withowt charge more to his own proffitt than the Q[ueen's].

Naturally Herle would have never used the office for gain at the Queen's expense, despite his willingness to do so in the case of the cloth surveying position.

Woodford used his position as the keeper of Herefordshire woods for financial profit, but Herle had planned 'cheefflye to make an entrye of speche \& familyarity with master Herryffords wydowe. ${ }^{12}$ Herryford had been the previous "woodward in that shire' and to Herle the office 'wolld have served for a good introductyon' to his widow. The widow herself was 'a propper yong gentillwoman of 28 yeres of aige' and 'without children.' More importantly, as far as Herle was concerned, she was:

lefft well furnisshed \& wellthye in howse \& movables, with [£267] a yere besyde whatt in lands \& leases, besyde the facilyty (if I were matched there) to compasse the gretter parte qwyckly of the feesymple that herryford had, to me \& my heyres.

\footnotetext{
11 ibid., f.29r-29v.

12 ibid., f.29v.
} 
Herle had 'fownd good lykeng bothe of her [the widow] \& her frynds,' and now asked Cecil and Elizabeth to provide 'som ayde \& cowntenance.'13

Herle was confident Elizabeth would support his suit, as 'I am incoraiged by her majesties own words [affectunes] repeted \& conffirmed' that she would 'favor \& cowntenance me, doing me ani resonable good she cowd. ${ }^{14}$ Herle added that the Queen had also promised to 'gyve me a [£66] pensyon by the yere,' though in bringing that up he emphasised, 'I am nether importunate nor a craver.' Herle was similarly confident of the Lord Treasurer's support.

There were, however, impediments to Herle's planned marriage to this rich widow. Foremost amongst these were his debts. Herle sought Crown protection from his creditors, asking Cecil to 'renew her majesties comandement uppon me till mydsomer next,' certifying that 'all mi busynes \& difficultyes by your L[ordship's] goodnes \& favor were settled \& stayed. ${ }^{15}$ He hoped that his status as a Crown servant would give him immunity from imprisonment for debt. Though Herle had already paid off 'a grett masse of detts' he could not 'dispatche the remnant so sone.' If Cecil could hold off Herle's creditors for a while longer, Herle hoped that 'bettwen this \& mydsomer' he could 'finisshe all.' Ironically, it appears that all that stood between Herle and the marriage that would settle his debts were those very debts.

Herle's debts continued to plague him, and in April 1574 he asked Cecil for help with his sorry state. Herle again claimed that the 'lease in reversion' Elizabeth had granted him for his work against the Ridolfi plot, worth $£ 50$, had already cost him more than $£ 60$ in extensive travel 'to seke owt partyculers to fille up the same' and 'make the most of mi booke [lease].' ${ }^{16}$ Herle admitted that his 'lack of skylle, how to dele in these

\footnotetext{
${ }^{13}$ ibid., ff. $29 \mathrm{v}-30 \mathrm{r}$.

${ }^{14}$ ibid., f.30r.

15 ibid.

${ }^{16}$ Herle to Cecil, 10 April 1574, BL MS Lansdowne 19, f.53r.
} 
matters...made it the derer \& harder unto me,' but also blamed 'Awditors \& other Clerckes, who lye in waytt to bye up bookes [leases] good chepe.'

The lease had produced less income than Herle expected, and what little there was his creditors soon collected. He asked for two privileges to compensate, that 'I maye have mi booke passe for 31 yeres, $\&$ where there is somwhatt more than [£50] in my sayd booke, that it may nott be stucke att. ${ }^{17}$ He worried that if 'the extraordinary yeres \& this littell overplus shold be taken away,' then 'the whole booke when it comes from the grett seale...will nott yelde clene unto me above [£250]' if sold. One of Herle’s creditors named Coleman had deducted $£ 50$ from Herle's lease proceeds 'for dett due unto hym by assignation,' and the remainder was too 'small to satisfye other men with.' Herle provided further details of the remaining funds in the lease a few months later, noting that it was made up of thirteen separate interests which Herle referred to as 'habendums,' the subsection of a deed that defines the estate granted, each worth $£ 3 / 3 /-$ for a total of $£ 40 / 19 /-.^{18}$

Herle claimed he stood on the brink of ruin. He assured Cecil that 'as God help me, I am driven to borow even from hand to mowth, to fede mi self with all. ${ }^{, 19}$ Worse still, his crippling debts meant that 'muche les am I hable to enter into ani new charge,' a particularly dangerous state for a Crown servant such as Herle who relied on the proceeds of his service for his livelihood. He asked Cecil to either permit him to flee overseas where he could alleviate his debt without fear of imprisonment by his creditors, or to intervene with them on Herle's behalf. These creditors were 'so gredy \& so inexorable, hoping to have even the extremity of their owne demands...that they have putt my bonds in sute secrettly. ${ }^{20}$ There is no evidence of these proceedings brought

\footnotetext{
17 ibid., f.53v.

${ }^{18}$ Herle to Cecil, 20 July 1574, BL MS Lansdowne 19, f.67r.

${ }^{19}$ BL MS Lansdowne 19, f.53r.

${ }^{20}$ ibid., ff. $53 \mathrm{r}-53 \mathrm{v}$.
} 
against Herle to bankrupt him and seize his remaining property, although if they were as secret as Herle claims this is unsurprising.

This letter shows how vital the protection of a powerful patron was to Herle. The situation threatened 'to bryng me to an owttlawry, unles her majestie \& your L[ordship] do favorably assiste me. ${ }^{21}$ Being outlawed for debt would not only cause Herle to forfeit all his goods, but prevent him from launching a counter-suit. Herle repeated his request that the Queen 'graunte me a Protectyon for a yere, therby to bryng them to som reson $\&$ to deffend mi self from prison.' By the end of 1574, Herle assured Cecil, he would be able to 'judge how eqwally \& justly I will dele with them [Herle's creditors] \& all others.' It was only through his patron's power that Herle stood a chance of avoiding utter ruin.

Cecil came to Herle's aid a few month later. In July 1574 Herle thanked Cecil for 'the favor shewed by the L[ord] Keper at your L[ordship's] motion. ${ }^{22}$ With Cecil's letter in hand, he had gone to Sir Nicholas Bacon, who acceded to Cecil's request to 'be good unto me in the chargs of my booke.' Bacon 'discharged with grett willingnes' $£ 20 / 9 / 6$, half 'the fees belonging to the sealle' needed for Herle's lease. Herle's experience showed how vital Cecil's powerful influence was to his entire future, for Bacon had 'so willingly don me good' only 'for your L[ordship's] sake. ${ }^{23}$

\section{The Waad Suit}

While Cecil enabled Herle to hold off the worst of his creditors and gain some recompense for his services, the situation became more complicated when Herle faced others with patronage ties as strong as his own. Herle's next few letters to Cecil describe his dispute with fellow monopolist in oil Armigal Waad's two sons, William and Thomas. Waad had died in 1568 , but managed to make his fortune through other

\footnotetext{
${ }^{21}$ ibid., f.53v.

${ }^{22}$ BL MS Lansdowne 19, f.68v.

${ }^{23}$ ibid., f.67r.
} 
investments in the interim, aided by a good marriage and the annuity of $£ 50$ per year he received for his service as a clerk of the Privy Council. ${ }^{24}$ Herle was vague about the suit's details, but it appears that he had borrowed at least $£ 100$ from the Waad brothers to repay his other, pressing creditors, but failed to repay them. ${ }^{25}$ In early November 1574 Herle told Cecil that he had attempted to settle the dispute out of court. Over the previous week both Herle and his brother in law, Laurence Johnson, had found Thomas Waad unwilling to discuss the matter. Thomas 'sheweth suche roughnes of speche \& suche extremityes, as thowgh he wold ether undo me clene, or ellse provoke me to som qwarrell with him, to withdrawe your L[ordship's] favor therby from me. ${ }^{26}$

Herle told Thomas Waad that William 'had refferred the whole matter' to Cecil's secretary Vincent Skyner's determination. ${ }^{27}$ Given Herle and the Waads' mutual ties to Cecil, Skyner seemed a logical choice for an arbitrator, but Thomas Waad 'wold nott enter into bond to stand unto master Skyners award' unless he could choose another to debate the issue with him. No court records survive of the suit between Herle and the Waad brothers, and we are forced to rely on Herle's account. However, in an earlier letter he had alluded to Skyner's offer to help Herle 'make som good end with master Wade,' so at least part of Herle's story was accurate. ${ }^{28}$

Herle claimed that Waad's suggestion would prove expensive and fruitless. Letting two lawyers negotiate a solution would 'entangle the matter more than to end it,' devour money, and sideline 'that conscyens \& charity that the cause required. ${ }^{29} \mathrm{He}$ countered with a compromise, that 'Skyner and Master Smith the customer' could mediate the dispute. Herle likely referred to Thomas Smythe, the wealthy merchant who

\footnotetext{
24 Michael Hicks, 'Armagil Waad (c.1510-1568),' ODNB, http://www.oxforddnb.com/view/article/ 28363, accessed 11 May 2010.

${ }^{25}$ Herle to Cecil, 9 August 1580, BL MS Lansdowne 31, f.22r.

${ }^{26}$ Herle to Cecil, 9 November 1574, BL MS Lansdowne 19, f.91r.

${ }^{27}$ ibid., f.91r.

${ }^{28}$ Herle to Cecil, 4 November 1573, BL MS Lansdowne 21, f.30r.

${ }^{29}$ BL MS Lansdowne 19, f.91r.
} 
collected London's import subsidies and was closely tied to Cecil and Leicester. ${ }^{30}$ Waad agreed at first, since 'master Smith was a fitt man for the purpose. ${ }^{31}$ However the next day he flew into a rage, asking 'if I sholld prescribe hym whom he sholld chuse for the determinatyon of his owne matters. ${ }^{, 32}$

Herle worried that his indebtedness to the Waads would affect his recovering social standing and career prospects. He told Thomas Waad that 'mi credyt dyd begyn to awgment,' and he was therefore loathe that 'every stranger sholld be privy to these grett bonds that he had of myne. ${ }^{33}$ Waad dismissed Herle's pretensions, saying 'he estemed nether me nor mi credyte' and demanded surety that Herle would abide by the arbitrators' decision 'beffore he wold prejudice his brothers right.' Waad offered an important insight into how Herle's contemporaries saw him. Waad considered Herle 'butt newly start up by the favor of som,' presumably meaning Herle's success under Cecil's patronage, and 'growen far to hawthy.' Obviously Herle's claims to gentility did not impress all who knew him. Herle passed on these criticisms, knowing they were also an implicit attack on Cecil. If Waad actually said what Herle alleged, it would help push Cecil to favour Herle over the Waads in the feud between his clients.

The arguments Herle presented to Cecil intimate that he had tried to use his standing with the Lord Treasurer to bully the Waads into agreeing to Skyner's arbitration. Herle warned Thomas Waad 'that his brother was more beholldyng to your L[ordship] than so hardly to use me,' and reminded him that Cecil 'for bothe our qwyettnes was desirows that he sholld suffer the matter to be taken up. ${ }^{34}$ This emphasises the leverage that the patronage system gave even to minor clients. Invoking Cecil's name gave Herle a significant advantage over his peers in negotiations, although

\footnotetext{
${ }^{30}$ Brian Deitz, 'Thomas Smythe (1522-1591),' ODNB, http://www.oxforddnb.com/view/article/37985, accessed 11 May 2010.

${ }^{31}$ Unfortunately Herle did not see fit to name these merchants, as it would have identified more of his creditors for us; BL MS Lansdowne 19, f.91r.

32 ibid.

${ }^{33}$ ibid.

${ }^{34}$ BL MS Lansdowne 19, f.91v.
} 
he would have been unwise actually to involve Cecil in anything short of a dire situation, making his threat somewhat hollow. When Thomas Waad called his bluff by refusing to agree to Herle's proposed arbitration, however, Herle had to ask Cecil 'to preserve me from undoing herin' by intervening himself. ${ }^{35}$ Herle concluded with an appeal to Cecil's self-interest in protecting his clients, asking that he 'whom your L[ordship] hath only raysed, therfore will have the more regard...that I may nott be over throwen by extremity.'

Unfortunately for Herle, the arbitration never eventuated. The following June he again wrote to Cecil, asking him to revitalise the negotiations. Skyner had been unable to arbitrate 'by reson of his contynuall attendance uppon your L[ordship's] servyce,' and Herle requested that the Treasurer allow Skyner half a day off to do so. ${ }^{36}$ It seems Herle had had to acquiesce to Waad's desire for a second arbitrator, as this letter placed 'master Hastings' alongside Skyner as an arbitrator of the dispute. If Skyner and Hastings proved unable to find a compromise, Herle hoped that Cecil 'wolld of your eqwity furnissh it.'

Cecil eventually agreed to help Herle, and in February 1576 Herle thanked the Lord Treasurer for his aid. His intervention had proved decisive, in 'advancyng me mi justyce towards som end of mi long sute. ${ }^{37}$ According to Herle's letters, when the Waad dispute resurfaced four years later in August 1580, both Cecil and Leicester had intervened on his behalf, 'in your littell chamber att White hall by the Tarresse' where they 'toke the payne to make an end for me with Thomas Wade. ${ }^{38}$ Leicester had agreed to pay the $£ 100$ that Herle owed Waad in two instalments of $£ 50$, one then and the other 'in November following.'

\footnotetext{
${ }^{35}$ ibid., f.92r.

${ }^{36}$ Herle to Cecil, 7 June 1575, BL MS Lansdowne 21, f.14v.

${ }^{37}$ Herle to Cecil, 1 February 1576, BL MS Lansdowne 24, f.60r.

${ }^{38}$ BL MS Lansdowne 31, f.22r.
} 
Soon afterwards Herle agreed to 'surrender his interest graunted by her Majesties 1[ett]res patents to him,' and transfer to William Waad his rights to the oil manufacturing monopoly he and Armigal had been granted. ${ }^{39}$ Felicity Heal and Clive Holmes have argued that Herle's request to transfer his patent was part of Cecil's wider policy of strengthening, stabilising, and increasing the wealth of England. ${ }^{40}$ From Herle's viewpoint, it was an enforced part of the deal that Cecil brokered.

By the time Herle wrote to Cecil accepting William Waad's monopoly over the making of oil, others had sought similar monopolies over oil production. Herle's letter focused on excluding foreign competition from the English market, probably in response to the competing application of the Italian Michel Andrione, and ensuring that Waad would have a ready supply of material through a conciliar command 'enjoyneng of men to sowe as muche grownd with rape \& cole seeds, as is provyded by statute, that they sholld sowe with lyne \& hemp. ${ }^{41}$ While Waad received his patent, Cecil recognised the futility of statutory enforcement such as Herle requested, for 'if it be more profitable [to farmers,] gain will avail more than law. ${ }^{42}$ The fact that Herle gave up his half of the patent is surprising when one considers how much political capital he must have spent garnering it in the first place. One can only conclude that it was either unprofitable, an unlikely state given that William Waad wished to acquire the whole patent, or that when Herle surrendered his interest in the patent he still owed the Waad brothers money.

Cecil's interventions, first to hold off Herle's creditors, then to ensure the payment of his lease, then to resolve his dispute with the Waads, left Herle financially settled for the first time in many years. He soon became embroiled in the negotiations between England and the Netherlands that will be discussed in Chapter IV. This fact

\footnotetext{
${ }^{39}$ Elizabeth I to Herle, [1576], BL MS Lansdowne 22, f.80r.

${ }^{40}$ Felicity Heal and Clive Holmes, 'The Economic Patronage of William Cecil,' in Croft (ed.), pp.211213.

${ }^{41}$ Herle to Cecil, 18 October 1576, HMC Hatfield MS Cecil Papers 9, f.42r.

${ }^{42}$ Heal and Holmes, p.213; BL MS Lansdowne 22, f.80r
} 
goes some way to explaining Cecil's intervention on Herle's behalf, after many years of ignoring his pleas. The Lord Treasurer needed Herle's skills to provide a backdoor channel for negotiations between himself, Elizabeth, and Orange's representatives in London. Herle's facility with languages, and extensive time spent in the Netherlands, made him the perfect man for the job. Despite Herle's ability to extract significant rewards and aid from Cecil, it appears that these were only forthcoming when Cecil needed him.

Herle's ugly suit with the Waad brothers resurfaced in August 1580. Cecil's previous intervention had clearly been less effectual than Herle claimed at the time, because he owed the Waads more money than he had revealed. He had been cast into the Wood Street prison by that August for not paying his debt to Thomas Waad. Waad now claimed that Herle had owed him $£ 200$, rather than the $£ 100$ that Leicester had agreed to pay on Herle's behalf in 1576, 'denying the substance of that agrement that passed. $^{43}$

By now the suit between Waad and Herle had become vicious. Waad had spoken with the Lord Treasurer at Cecil House, trying to undermine Herle's standing, and 'entred four actyons agaynst me of [£667] to vexe me \& kepe me for all together.' 44 According to Herle, Waad's claims had rapidly increased from $£ 100$ to $£ 200$ to over $£ 600$, leading to his imprisonment. Herle responded by asking Cecil to ask Leicester to retrieve the contract Waad had signed, currently held by 'Ambrose his man,' so that the two Councillors could recall the terms of the agreement. ${ }^{45}$ Herle then hoped that it might plese your Lordships bothe, to write 3 lynes to the sayd Waade, of the agrement that passed. ${ }^{46}$ Herle also asked Cecil to "write fryndlye to Master Jasper Sowthcote [the

\footnotetext{
${ }^{43}$ BL MS Lansdowne 31, f.22r.

${ }^{44}$ Herle to Cecil, 9 August 1580, BL MS Lansdowne 31, f.22r.

45 ibid.; This could refer to Ambrose Butler, one of Leicester's gentleman retainers during his Netherlands expedition; Simon Adams, Leicester and the Court, p.394.

${ }^{46}$ BL MS Lansdowne 31, f.22r.
} 
head jailer in Wood Street] to take resonable byll for mi apparence that next Terme. ${ }^{47}$ This time Cecil complied, and Herle's next surviving letter makes it clear that he had been released from prison some weeks before September $1580 .^{48}$

In early 1581, Waad's suit against Herle again emerged. Herle was not imprisoned this time, but he complained to Cecil that he 'shalbe forced to be a Banisshed man owtt of myne own contry' unless he received protection. ${ }^{49}$ Herle asked Cecil to join with Leicester in persuading Walsingham to ward off Waad as 'on word of master Secretoryes may end it.' More specifically, Herle had arranged for $£ 150$ he now acknowledged he owed Waad to be paid: $£ 100$ from two Exchequer officials, masters Osburne and Fanshaw, who owed Herle money, $£ 10$ from Herle's brother in law Laurence Johnson who 'hath a Bond of Wades brother' Thomas, and the remaining $£ 40$ from Leicester's own pocket. ${ }^{50}$ This mention of $£ 150$ is particularly interesting, since with the $£ 50$ Leicester had previously paid Waad on Herle's behalf, it corresponds to the $£ 200$ figure Waad had claimed Herle owed him the year before. As Herle had previously told Cecil that Waad was inflating this figure from the $£ 100$ Herle actually owed him, it may have caused the Lord Treasurer to doubt Herle's honesty.

Unfortunately for Herle Leicester was slow in keeping his promise. In May 1582, over a year later, Herle asked the Earl to please 'end the cawse with Waade, accordynge to your honorable promis...\& disberse the [£40] which of your goodnes ye had offred towards the discharge of the sayd dett. ${ }^{51}$ Herle also wrote to Walsingham, asking the Secretary to aid him in the 'cawse that suspends betwen master Waad \& me. ${ }^{52}$ No replies survive from either Leicester or Walsingham, but another letter Herle sent to Walsingham indicates that both eventually helped him, in June 1582.

\footnotetext{
${ }^{47}$ ibid., f.22v.

${ }^{48}$ Herle to Cecil, 26 September 1580, BL MS Lansdowne 31, ff.30r-30v, 33r-33v.

${ }^{49}$ Herle to Cecil, 6 March 1581, TNA SP 83/15/46, f.108r.

50 ibid.

${ }^{51}$ Herle to Leicester, 13 May 1582, BL Cotton Titus B VII, f.44r.

52 TNA SP 83/16/13, f.26r.
} 
Upon returning to Antwerp after a mission to Holland, Herle received letters from the two Councillors. These were 'bothe so tenderlye wrytten, with suche honorable respect to mi poore cawses there, as I thynk mi sellf bownd to ether of yow, whiles brethe $\&$ memorye remaynes. ${ }^{, 53}$ Herle thanked Walsingham for promising to help him gather the money he owed Waad, and agreed to apologise to Waad for taking so long to pay his debts. Herle's letters do not mention the Waad suit again, and it seems that with Walsingham's help it was finally ended for good. Despite Herle's letter to him, Walsingham's intervention was likely for Waad's benefit, as both he and Cecil supported Waad's bid for a post as clerk to the Privy Council the following year. ${ }^{54}$ Settling any long-standing feuds of Waad's would have been a necessary precursor to making his bid, and it is likely that this was Walsingham's primary concern.

The difficulties Herle had in settling the Waad dispute had encouraged him to curry favour with several patrons rather than focusing exclusively on Cecil. This brought short-term benefits, as both Leicester and Walsingham's intervention was required to end the Waads' suit against him, but proved problematic in the long run. Tying himself to multiple powerful men was only a valid strategy as long as their interests coincided. There was no guarantee that what one councillor wanted Herle to do would not antagonise another. Up until the mid-1580s, however, there was little doubt that Herle was primarily Cecil's man, a fact which is further shown through his appeals to Cecil regarding a office which had been granted to him in the 1570 s.

\section{Herle and the Cardiganshire Gentry}

Even while Herle struggled to end his dispute with the Waad brothers in early 1577, the people of Cardiganshire accused him of abusing the office of Rhaglaw in their shire. Herle had been granted a lease on the office of Rhaglaw in November 1573, an

\footnotetext{
${ }^{53}$ TNA SP 83/16/34, f.65v.

${ }^{54}$ See above page 24.
} 
office whose duties largely consisted of gathering rents. ${ }^{55}$ Herle himself described the Rhaglaw as existing 'long before the Conqwest \& was a sheriff, which name \& office contynewes to this daye \& not begon in ani tyme of Rebellyon, to be abrogated when the cawse of his office cessed., ${ }^{56}$

Herle's involvement with the people of Cardiganshire is one of the few areas of his life that has received detailed historical study. David Lewis Jones, however, approached the issue by deriding Herle's 'devious career,' as an 'odious...prison spy' who took part in a "piratical attack. ${ }^{, 57}$ All of these criticisms are true, if harshly phrased, but Jones ignores Herle's loyal service to the crown and devotion to Cecil's cause. His analysis of the confrontation between Herle and the people of Cardiganshire is similarly imbalanced, painting a picture of Herle as a villainous oppressor, eager to grasp every last penny the locals had.

Herle had initiated an Exchequer case in November 1576, accusing Cardiganshire locals of withholding rent from the government. Upon questioning by the judges, the majority of the defendants agreed to pay Herle, but a number refused. ${ }^{58}$ Herle renewed his prosecution in 1577 , targeting the recalcitrants, but they countered by writing to Cecil, who forwarded their complaint to Herle for his response. The men of Cardiganshire described Herle as 'an unkinde and cumbersome man to his owne country people,' and claimed that they had been willing to pay a rent of ' 20 s by the year' but no one had collected it. ${ }^{59}$ Even though Lewis Jones shared that opinion of Herle, he admits that 'this was not entirely correct, probably through guile rather than innocence. $^{, 60}$

\footnotetext{
${ }^{55}$ Lewis Jones, 'William Herle and the Office of Rhaglaw,' p.161.

${ }^{56}$ Herle to Cecil, 19 March 1577, BL MS Lansdowne 28, f.85r.

${ }^{57}$ Lewis Jones, 'William Herle and the Office of Rhaglaw,' p.161.

58 Although he did not write of it in 1576, Herle detailed his previous troubles with the men of Cardiganshire when they arose again in 1577; BL MS Lansdowne 28, f.84v.

${ }^{59}$ Unknown to Cecil, Undated but probably 1577, BL MS Lansdowne 28, f.109r.

${ }^{60}$ Lewis Jones, 'William Herle and the Office of Rhaglaw,' p.168.
} 
Herle responded to Cecil in March 1577, accusing the Cardiganshire complainants of lying and slandering him. 'Besyde the fallshod of their suggestion,' argued Herle, 'they leve all owtt that appertaynes to the matter in theyre complaynt. ${ }^{61}$ Those who wrote it were not poor, and merely styled themselves as such while keeping the rents due to the Queen for themselves, 'whereby [£666] have ben gathered this way.' The claim that 'nether awditor nor recevor hathe demanded the rent insomani yeres' was patently false. Previous attempts to extricate the rents had been 'certefyed into the Excheqwer.' Herle claimed that he had gone out of his way to deal kindly with the people of Cardiganshire, and 'never woulde suffre man to be ymprisoned, but was a suter withall to the Court, to have ther fynes remitted.' Nothing seems to have come of this exchange of letters sent to Cecil, but the following year the matter was raised again.

In late June 1578, Herle asked Cecil to intervene personally in his dispute with the men of Cardiganshire. The situation had altered, as now the Cardiganshire gentry were attempting to purchase the Rhaglawship. Herle described the man trying to buy the office as 'pryses brother in Lawe,' almost certainly referring to John Price of Gogerddan. ${ }^{62}$ Price's family were the most powerful members of the gentry in Cardiganshire, and he was probably instrumental in organising the previous resistance against Herle. Now, however, he wished to buy Herle's office for $£ 1,000$. Herle was amenable to the sale but was 'standyng styfflye uppon mi demande' of $£ 3,000 .{ }^{63} \mathrm{He}$ now asked the Lord Treasurer to use his 'awthoritye \& good favor' to 'drawe theme to the som' of $£ 1,500$. Herle thought that the members of the gentry whom Price represented would be 'glad...to com unto [that price], in respect of your honorable cowntenance \& goodnes to theme herafter.'

\footnotetext{
${ }^{61}$ BL MS Lansdowne 28, f.84r.

${ }^{62}$ Lewis Jones, 'William Herle and the Office of Rhaglaw,' p.167.

${ }^{63}$ Herle to Cecil, 27 June 1578, BL MS Lansdowne 78, f.92r.
} 
It appears Cecil intervened on Herle's behalf. On February 15 1579, Herle thanked Cecil for 'bryngeng mi werysom sute, so long deppending yn the Excheqwer towards som more certayn conclusyon. ${ }^{64}$ Despite Herle's elation, haggling continued until June 1581 when he could finally write to Sir Walter Mildmay, the Chancellor of the Exchequer, about his success in selling the Rhaglawship. Despite the extensive legal proceedings, and the negotiations for sale which followed them, the matter had been settled in such a way that 'the tenants \& comodites lyable to the said office, as they \& the whole contrey are highelie contented $\&$ pleased...with the freedom that they $\&$ their posteritie ar to receve ther by. ${ }^{65}$

Herle could have only felt relief at the end of a gruelling series of court cases. He detailed the means by which payment for the office was to be made to him and his creditors:

They having compownded with me, to paie into the handes of certayne feoffies of trust vz. to master Fanshawe, master Osburne, master customer Smythe \& others [£1,600] for the said feeffarme and the arreraigs. ${ }^{66}$

With the promise of money coming in to pay off his debts, Herle hoped that Mildmay would release his 'pensyon in the Exchequer' which was being stayed from payment 'at the sute of on Lynfford a servante of master Carye,' another of Herle's creditors. Lynford, said Herle, could 'take in equitie \& reson his satisfactyon as the other creditors do' rather than interfering with his pension 'which is the onlie thing that I have to lyve upon.'

In the period between his letter to Cecil of 1579 , when he expected to sell the office, and his letter to Mildmay of 1581, when he had finally arranged the sale, Herle's financial difficulties had been growing steadily worse. Mere days after his hopeful letter to the Lord Treasurer, Herle wrote to Cecil again, this time from a more perilous

\footnotetext{
${ }^{64}$ Herle to Cecil, 15 February 1579, BL MS Lansdowne 29, f.132r.

${ }^{65}$ Herle to Sir Walter Mildmay, 17 June 1581, TNA SP 12/149/43, f.109r.

66 ibid.
} 
position. Vincent Skyner, Cecil's secretary who had arbitrated Herle's dispute with the Waad brothers, had also lent Herle money. Herle informed Cecil that in violation and 'contempt of the Cowncelles warrant' Skyner had imprisoned Herle to regain the money he lent him. ${ }^{67}$ Skyner, alleged Herle, paid a number of sergeants $£ 10$ to 'bryng me dyrectlye to prison \& to leve me there,' despite having previously told Herle that 'he wolld bere with me tyll Ester Terme.'

A large part of Herle's outrage at this incident seems to have been the embarrassment it caused him. He alleged that Skyner had told him that 'he wolld arrest the prowdest of those, that do owe hym money in Cowrtt, yf ether he durst or myghte. ${ }^{68}$ Such foolish words, said Herle would enable Cecil to see 'the presumptyon of the man, \& the upbraydeng of those,' including Cecil, 'that by their liberalitye have made hym.' Herle thus sought to alienate Cecil from Skyner, and requested that he revoke the warrant that held Herle in prison. No evidence survives to show whether Cecil asked Skyner to drop his suit against Herle.

Throughout the late 1570 s and early 1580 s, Herle's financial problems had forced him to ask much from his patrons. During the three legal disputes detailed above, Herle was forced to expend much of the capital he had built up with Cecil during the preceding years. The limits of patronage are revealed by Herle's difficulties in dealing with those who had similarly powerful connections to Cecil, such as Skyner and the Waads, or those who were remote from Cecil's sphere of influence, such as the gentry of Cardiganshire. Despite this, it is clear that until the mid-1580s Herle was relatively successful in using his leverage with Cecil to advance himself and deal with the resultant issues.

\footnotetext{
${ }^{67}$ BL MS Lansdowne 29, f.134r.

68 ibid., f.135r.
} 


\section{Cecil and Herle's Argument}

In late 1585 Herle's client relationship with Cecil threatened to dissolve completely in the face of accusations of misdeeds on Herle's part. Their argument occurred shortly after Herle tried to ingratiate himself with Cecil by reporting slanders against Cecil and his son Robert. Herle often included such details in his letters, but the aspersions detailed in this letter were particularly vicious, focusing as they did on Cecil's excessive influence, with undisclosed persons claiming 'thatt England was becom Regnum Cecilianum, your bylldengs ynfinite, \& eqwall to Kings Palacs. ${ }^{69}$ Cecil responded mere days later, thanking Herle for his vigilance and detailing a list of answers to the slanders that he wished Herle to make known. He finished the letter with a sentence which was to cause significant difficulties for Herle: 'Yow si, how I am carryed by these provocations to wryte more than I intended, and yet I wryt nothyng, but I will affirme in presence of any Company good or bad. ${ }^{70}$

In Herle's reply to Cecil, he implied that he planned to accept Cecil's offer to affirm the statements by showing it to 'som of mi frynds (not many) of the better sort, that mene well, but waver with the sondry and vehement ympressyon of others. ${ }^{, 71}$ Cecil's rapid response to this throw-away line accused Herle of showing Cecil's private letters around town. Herle's use of Cecil's patronage had clearly become excessive in the eyes of Herle's rivals, because they had 'friendly informed' Cecil that:

you mak ostentation of your greatness with me and do send all my $1[\mathrm{ett}] \mathrm{res}$ abrod in the Cite, which I send yow. I am well content that every man shuld know that I lyk yow. But to send and disperss my $1[\mathrm{ett}] \mathrm{res}$ in that sort I can not allow. ${ }^{72}$

What worried Cecil, it seems, was that 'many may think grett levity in me, to have my privat $1[\mathrm{ett}] \mathrm{res}$ in this sort spred abrod.'

\footnotetext{
${ }^{69}$ Herle to Cecil, 11 August 1585, TNA SP 12/181/32, f.133v.

${ }^{70}$ Cecil to Herle, 14 August 1585, TNA SP 12/181/42, f.155v.

${ }^{71}$ Herle to Cecil, 21 August 1585, TNA SP 12/181/56, f.190r.

${ }^{72}$ Cecil to Herle, 24 August 1585, TNA SP 12/181/60, f.198r.
} 
This highlights the problems raised by the Elizabethan practice of placing matters of state concern and personal nature in the same letter, as well as the often verbal nature of patronage. Robyn Adams has argued that the difference between showing letters to others and reading them aloud was particularly significant in this period, as the latter allowed for careful editing and removal of personal comments. ${ }^{73}$ Cecil and Walsingham, for example, read most of Elizabeth's correspondence to her, allowing them to tailor the contents as they went. Herle's reply emphasised the entirely verbal nature of his mistake. Herle denied showing the letters themselves, explaining that all he had ever done was tell others 'of your favor, or of ani grettnes that I have with yow,' and that though this 'might argue a foolyssh zele \& presumptyon in me, thowgh no discretyon, which truly I never dyd. ${ }^{74}$ Further, he asked that Cecil inform him 'to whom, when \& how I dispersed your sayd 1[ett]res.' 75

Cecil did not deign to reply to Herle's request for details of his misdeeds for two months, and when he did it was in the form of a scathing rebuke:

That I charged yow with dispersyng my privat $1[\mathrm{ett}] \mathrm{res}$ abrode, I am worthewise suer, but that they which did se them, yea some that saw them also whan yow sent them to the Court, yea to Counsellors. And as ther Creditt is with me, so and in that proportion I am moved to thynk it trew. And therfor I desyre to have my $1[$ ett $]$ res back. ${ }^{76}$

The phrase 'yow sent them to the Court, yea to Counsellors' implies that Herle had over-stepped the bounds of clientage and favour by distributing unedited letters, which had given ammunition to rival Councillors. Perhaps Cecil had been indiscreet in letters to Herle that do not survive, attacking other Councillors. Read assumed that the letters Cecil referred to were the defences of his actions detailed above. Even as ardent an apologist for Cecil as Read was forced to concede that if this was so the Treasurer was

\footnotetext{
73 Adams, 'Both Diligent and Secret,' p.81.

${ }^{74}$ Herle to Cecil, 24 August 1585, TNA SP 12/181/61, f.199r.

${ }^{75}$ Herle to Cecil, 28 August 1585, TNA SP 12/181/70, f.216r.

${ }^{76}$ Cecil to Herle, October 1585, TNA SP 12/181/71, f.218r; This letter is undated, and was endorsed as 'March 1589' by a twentieth-century archivist based upon its details of Cecil's wife's illness (she died on 7 April 1589). The fact that Herle was dead at this point, however, makes this impossible. October 1585 seems more likely, given its content and Herle's more accurately dated subsequent reply.
} 
acting in a distinctly odd fashion, asking Herle to answer accusations against him one week and then attacking him for doing so the next. ${ }^{77}$

In the face of Cecil's suspicion and demand for the return of his letters Herle scrambled to apologise and comply, admitting 'I am most humbly to obey yow,' hoping this had not 'trobled your L[ordship] withal,' and trusting that he had 'mi sellf nott prejudicated by ani sinister oppynion. ${ }^{78}$ Herle's relationship with Cecil survived this disaster, although it never seems to have been as close again. The fact that Cecil could withdraw his patronage from Herle for months at a time highlights exactly how dependent Herle's life had become on the whims of one man. When seen in conjunction with his success in ending the Waad case by securing the support of several Privy Councillors, it is no wonder that Herle came increasingly to rely on several patrons.

\section{Herle's Patronage Revisited}

During the 1580s, Herle's interaction with Councillors other than Cecil steadily increased. His involvement in uncovering the Throckmorton plot and leading an embassy to East Friesland, discussed in Chapter V, brought him closer to both Walsingham and Leicester. While Cecil remained his primary patron, there is a distinct sense that Herle was diversifying his patronage base. Two letters of October 1586 exemplify Herle's changing circumstances, and show how he employed the support of multiple patrons for his advancement.

By 21 October 1586 Herle was acting as a courier for Leicester, taking messages between the Earl, Elizabeth, and Cecil. Leicester had dispatched him to Elizabeth with 'sondry cawses of ymportance,' with instructions to return upon completing his tasks. ${ }^{79}$ Herle described himself as a liaison between Cecil and Leicester, informing Cecil that the Earl had 'charged me, in ani matter that conserned him, or mi sellf (coming from

\footnotetext{
${ }^{77}$ Read, Lord Burghley, pp.318-322.

${ }^{78}$ TNA SP $12 / 181 / 72$, f.219r.

${ }^{79}$ Herle to Cecil, 21 October 1586, BL MS Lansdowne 51, f.41r.
} 
him) to addresse mi sellf to your L[ordship] freely.' This implies that Herle was no longer so dependent on Cecil's goodwill that he had to emphasis his subservience in language and gesture.

Herle was evidently relying on Leicester's backing in this proposal, a fact which indicates that the disagreement between Herle and Cecil over the latter's letters the year before may have had lasting consequences. The vast majority of Herle's surviving correspondence was still with Cecil, which suggests that they still shared a close patronclient relationship even if Cecil had personally withdrawn. Yet it could be argued that the surviving letters fail to reflect reality, because the majority of Leicester's private correspondence has not survived. It is possible that by this point the Earl was Herle's primary patron. Leicester had for years been more eager to intervene on behalf of the Dutch, a cause close to Herle's heart. However, the surviving evidence only allows us to conclude that Herle had greatly increased his ties to another Councillor.

Further evidence of Herle's current rise in the esteem of Councillors other than Cecil can be seen in a letter of 26 October 1586, in which two of Elizabeth's secretaries discussed who would be granted the important post of clerk to the Privy Council. Thomas Dannet informed William Davison that he had spoken to Cecil's son Robert while visiting the Lord Treasurer at Windsor, who had told him 'he shoulde neither doe yowe nor me pleasure, in this cause of the clarkeshipp of the Councell because he thought it woulde be bestowed uppon Herle. ${ }^{80}$ In 1586 Robert Cecil was only 23 years old and, despite his rapid rise as assistant to his father, would certainly have had little say in this appointment. ${ }^{81}$ Dannet was using the younger Cecil to gauge his father's opinions, and feared that William Cecil 'hadd a propos to place Herle. ${ }^{82}$ Dannet himself had the support of Sir John Wolley, Elizabeth's Latin secretary who acted in

\footnotetext{
${ }^{80}$ TNA SP 12/194/60, f.130r.

${ }^{81}$ Alford, Burghley, pp.300-301.

${ }^{82}$ TNA SP $12 / 194 / 60$, f.130r.
} 
Walsingham's place as Secretary during his frequent bouts of illness. ${ }^{83}$ Dannet did not think much of his chances with Wolley's backing against Herle with Cecil's, lamenting that 'it shalbe my misfortune to receive a foile by meanes of Herle.' ${ }^{84}$

It was not Herle who proved Dannet's foil. Despite Cecil's support, and presumably that of Leicester, Herle lost the post to Sir Anthony Ashley, who enjoyed Hatton's support. ${ }^{85}$ Hatton's close personal relationship with the Queen proved decisive, and Ashley's appointment also enabled Elizabeth to balance Hatton's more conservative outlook against Leicester and other Councillors' Godly Protestantism. Herle had failed to secure the position despite Elizabeth's verbal appointment. The following year, Herle reminded Elizabeth that 'your majestie graciouslye...appoynted me with many good woords a yere past, to succede master Beale in the Clerckship of the Cowncell,' and lamented that 'others...had obtayned' it despite her promises. ${ }^{86}$ Missing out on this post was a major blow to Herle's career, as it provided income, prestige, and ready access to the most powerful men in England.

It is possible to illustrate exactly how such a posting could make a gentleman's career by comparing the previous and subsequent career arc of one of Herle's contemporaries, who succeeded in becoming a clerk of the Privy Council a few years earlier. William Waad, Herle's nemesis throughout the 1570 s and 80 s, had received a clerkship in 1583 with Walsingham and Cecil's support. ${ }^{87}$ Waad was a generation younger than Herle, and had been educated at Gray's Inn. Unlike Herle, Waad had the benefit of a father who had been in Cecil's service for many years, and his early career consisted largely of European travel as secretary to a number of ambassadors.

\footnotetext{
83 Glyn Parry, 'Sir John Wolley (d.1596),' ODNB, http://www.oxforddnb.com/view/article/29844, accessed 11 May 2010.

${ }^{84}$ TNA SP 12/194/60, f.130r.

${ }^{85}$ Michael Hicks, 'Sir Anthony Ashley (1551/2-1628),' ODNB, http://www.oxforddnb.com/view/article/ 757, accessed 11 May 2010.

${ }^{86}$ BL MS Lansdowne 54, f.151r.

${ }^{87}$ Gary Bell, 'Sir William Waad (1546-1623),' ODNB, http://www.oxforddnb.com/view/article/28364, accessed 11 May 2010.
} 
It was not until Waad received the clerkship in 1583 , however, that his career truly took off. After an embassy to Vienna in 1583 he was made ambassador to Spain in 1584 and to France in $1587 .{ }^{88}$ After his return from France he was instrumental in the government's attack against recusants and Jesuits, and eventually served at various parliaments during 1585-1604. Knighted in 1603, Waad became Lieutenant of the Tower. A successful career in diplomacy and administration such as Waad's was probably the most Herle could have aspired to. His failure to secure the clerkship was a severe blow to his chances of taking the next step up the social and political ladder. While Waad rode Walsingham and Cecil's support to a clerkship in 1583, Herle proved unable to do the same in 1586.

\section{Financial Collapse}

After this failure, Herle's life began to spiral downwards. The surviving evidence indicates that his failure to secure further rewards was due to a combination of his declining leverage over his established patrons, and the increasing influence of Councillors he had few ties to, particularly Hatton. Herle's later surviving letters are largely concerned with his inability to pay his mounting debts. He tried all his previously successful strategies throughout 1587, asking Cecil, Leicester, and Elizabeth for aid, begging to have his debts stayed, and offering to do any service he could in exchange for assistance. However, none of Herle's patrons relieved him, a fact which he blamed on Hatton's malevolence.

In January 1587 Herle began a series of letters pleading for Cecil to help him with his financial difficulties. ${ }^{89} \mathrm{He}$ asked for repayment from the Crown for the expenses he had incurred during his various missions to East Friesland, hoping that 'som tender consyderacion be had of mi poore estate, \& of the long pacyens I have

88 ibid.

${ }^{89}$ Herle to Cecil, January 1587, BL MS Lansdowne 55, ff.204r-204v; An exact date for this letter is not given by whichever of Cecil's secretaries filed it, and neither its contents nor its placement in the Lansdowne papers provide further clues. 
endured, having had no releeff these 4 yeres att her majesties hands.' Herle claimed that he had only received $£ 100$ recompense for the money he had spent on all his 'chargeable vyages...abrode.' As these journeys were made 'by her majesties owne choyse \& comandement,' Herle felt he should not bear the cost himself. These arguments repeated those Herle had been unsuccessfully making his whole career, but where he had previously gained some small recompense, he now gained none.

Herle's patrons were clearly uninterested in granting Herle's requests, indicating his declining utility. Although Herle noted that 'her majestie bestowed on me by paroll [verbally] a [£100] pencion’ Cecil had not organised its confirmation, and Herle implied that it had been sitting on the Lord Treasurer's desk for ten weeks. ${ }^{90}$ Nor was Cecil the only patron who was ignoring Herle. Herle asked Cecil to 'move favorably on mi behallf' with Walsingham, 'withowt whose furtherance I shalbe never hable to advance. ${ }^{91}$ It could be argued that the letter's phrasing made it a gentle rebuke, asking the Treasurer to remember his duty as patron and ensure the just reward of his client.

Herle's invocation of Elizabeth's role as the chief patron in England implied that Cecil's delay in bestowing her benevolence would be overstepping his authority. 'I humbly presume,' wrote Herle 'that it is far from her Royall disposityon, ether by defferryng, to demynisshe the qwality of her gyffte, or by withdrawing from her pryncely woorde ani parte of the substance therof, to depryve me of hope \& of it together. ${ }^{92}$ The rebuke demonstrates how significantly Herle's patronage relationship with Cecil had been affected by their falling out in 1585 . Despite the critical undertone of the letter, however, Herle finished with an appeal to Cecil's conscience, claiming that he was not 'hable to endure ani longer delaye, nor the expences that may succeede.'

\footnotetext{
90 ibid., f.204r.

${ }^{91}$ Herle to Cecil, 5 January 1587, BL MS Cotton Galba C XI, f.76r.

92 BL MS Lansdowne 55, f.204r.
} 
Cecil failed to respond as swiftly as Herle hoped. In early February 1587, Herle wrote a short note to Cecil so that he might 'be humbly remembred of mi state \& neede. ${ }^{93}$ Nor had his situation improved by 21 February, when Herle begged Cecil to 'attend your opportunitye for mi releeff att her majesties hands. ${ }^{94}$ Herle tried to emphasise, despite his previous attachment to Leicester, that he could 'relye of non butt your sellf theryn' as Cecil was 'the sole hellpe \& mediator' of his 'harde state.' Herle's claim to rely solely on Cecil's benevolence to solve his financial difficulties by appealing to the Queen, illustrates Leicester's declining influence in the aftermath of Elizabeth's fury at his acceptance of the governor-generalship of the Netherlands.

When Cecil finally appealed to Elizabeth on Herle's behalf, things did not go as Herle had expected. In late March Herle thanked Cecil for taking his suit to the Queen, but admitted his disappointment at 'the diffinityve sentence that her majestie hath given to your L[ordship] towching me. ${ }^{95} \mathrm{He}$ could not criticise Elizabeth too heavily, claiming that 'I am most humbly contented with her good plesure, whattsoever she decree.' Throughout this letter, however, Herle sprinkled critiques of Elizabeth's capricious nature and implicitly of Cecil, saying that 'she hath graciously accomplisshed to others (better frynded) \& I alone excluded \& contempned, after the disbursement of myne owne, ye all \& more then I had, in her service, as yett unallowed or recompensed.' Given these criticisms, and the absence of any reply from Cecil to Herle's earlier letter, it seems likely that the two had met in person in the interim, and that Cecil had attributed Herle's lack of reward to the Queen's declining opinion of him.

A month later Herle wrote to Elizabeth, asking her to ignore those who demeaned his good name to her, and solve his financial difficulties. He complained that those who had 'sowght mi disgrace \& undoing with your majestie...have informed that I

\footnotetext{
${ }^{93}$ Herle to Cecil, 2 February 1587, BL MS Lansdowne 55, f.205r.

${ }^{94}$ Herle to Cecil, 21 February 1587, BL MS Lansdowne 55, f.210r.

95 BL MS Lansdowne 55, f.217r.
} 
am a raver, thatt yow have bestowed uppon me manifold things' despite Herle's protestations of poverty. ${ }^{96}$ Elizabeth, these anonymous attackers claimed, had given Herle over $£ 2,000$. Herle responded to these accusations by listing the rewards he had received from Elizabeth for his service to her:

I only had duryng mi service 2 gyfftes, \& those nott propperly of mi sute, butt of your free disposityon, The first a lese in reversyon, \& the other a pencion, which may be valued att bothe to [£900] for gyfftes bestowed on me in the placs of mi employment, besyde a chaine worth [£50].

Herle's claim that he only received ' 2 gyfftes' is clearly false. As detailed above, he had also received a patent, a position as porter of the Tower, and a position as Rhaglaw of Cardiganshire, not to mention Cecil's aid in staying his debts repeatedly. The only way Herle's statement to the Queen could be considered true is if he believed all these other rewards were granted purely through Cecil's influence.

Herle's downplaying of the rewards he received for his service makes perfect sense when taken in conjunction with his focus on the expenses the same service had cost him. Herle claimed that he was 'so far from benefyteng' through his service that in East Friesland had cost him $£ 860 .{ }^{97}$ Herle estimated the entirety of expenses accrued during the course of his career at $£ 4,500$. He asked Elizabeth to consider 'mi weke estate' and 'inhable me at laste, with somwhat convenyent for me in reputacion \& comoditye.' Elizabeth followed a similar patronage strategy to Cecil. While she did not grant Herle any secure offices or pensions, 'she sollicited master Secretory her sellf, to provyde som convenyent staye for me' and hold off his creditors a little while longer. ${ }^{98}$

Elizabeth's intervention failed to solve Herle's problems, and he continued to bombard his patrons with requests for money throughout 1587. In July Herle told Cecil that he had 'morgayged \& forffayted mi pencyon. \& burdened my frynds above mesure,

\footnotetext{
${ }^{96}$ BL MS Lansdowne 54, f.151r.

97 ibid.

${ }^{98}$ BL MS Lansdowne 54, f.150r.
} 
among whom master Secretory hath answerd \& payd for me’ $£ 155 .{ }^{99}$ Yet even with Walsingham's help his debts continued to mount. 'There rests' said Herle, 'nothing more to sacrifise, butt mi lyfe, which is redy for ani service of the state.' Herle's appointment to expensive duties such as ambassadorships, combined with his failure to secure well paying offices, placed him in an unwinnable situation. Herle was obviously aware of this, repeatedly attempting to secure such lucrative offices through Cecil. Even as he lamented his unpaid debts, Herle noted that 'master Hayes on of the awditors of the duchye is this daye decessed, the gyffte of whose office is meerley in her majestie,' and asked the Treasurer to intervene with Elizabeth so that she would bestow it upon Herle. ${ }^{100}$ Cecil, it seems, did not.

Herle failed in every suit during 1587, which he blamed on Hatton's influence. In August [1587], having been passed over for yet another office, Herle complained that the recently appointed Lord Chancellor was undermining him. When Herle applied for the 'clerckship of the casuall fynes' Hatton 'bestowed it uppon his kinseman Fr[ancis] Flower;' when he 'sued by $1[$ ett]re for Tussers office of the duchie...it was yett ones agaynst crossed by the L[ord] Chancellor. ${ }^{\text {, }}{ }^{1}$ Even his application for the 'Clerckship of the Cowncell' had failed because of Hatton's intervention. Herle's portrayal of a personal vendetta is explicable if we accept that Hatton saw Herle as Cecil and Leicester's partisan in the Protestant cause, supporting aggressive foreign policy which Hatton opposed. An alternative explanation is that Hatton's influence in these matters had begun to eclipse Cecil's, and the service Herle could provide could not recompense Cecil for expending his influence with the Queen.

Herle had benefited greatly from Cecil's dominance of patronage over the years, but by the late 1580 s the Lord Treasurer's ability to reward his servants had clearly

\footnotetext{
${ }^{99}$ Herle to Cecil, 24 July 1587, BL MS Lansdowne 54, f.145r.

${ }^{100}$ Herle to Cecil, 26 July 1587, BL MS Lansdowne 54, f.147r.

${ }^{101}$ BL MS Lansdowne 54, f.150r.
} 
diminished. The loss of personal influence over Elizabeth when Cecil stepped down from the position of Secretary, was only partially made up for by his new role as Lord Treasurer and Master of the Court of Wards. Cecil moved closer to Elizabeth again through his role in the Anjou marriage negotiations, but his central role in tricking the Queen into signing Mary Stuart's death warrant in 1587 led to his dismissal from Court. In contrast, Hatton's influence grew steadily from his induction into the Privy Council in 1579. Wallace MacCaffrey has argued that Hatton's support was considered crucial by other councillors due to his high degree of personal influence over Elizabeth. ${ }^{102}$ This influence, when combined with Elizabeth's bestowal of the Lord Chancellorship on Hatton in April 1587, gave Hatton immense influence over Crown patronage. In much the same way that Cecil and Leicester's affinities had benefited from the peaks in their power, so Hatton's followers benefited in the 1580s. Herle was unfortunate enough to seek positions at a time when Hatton was busy rewarding his established clients.

This chapter has examined Herle's interactions with his patrons throughout several decades. Herle's letters allow us an unprecedented glimpse into the minutiae of patronage relationships, demonstrating a number of consistent themes. While patronage involved a mutually beneficial relationship where the patron rewarded his client for loyal service, as was argued in Chapter I, this did not always eventuate in practice. Herle's relationship with Cecil seems to have involved rewards for future possible services as much as it did those for recent ones. This was based around the ability of a client such as Herle to exert leverage over his patrons. In the aftermath of the Ridolfi plot, Herle was eminently useful to Cecil, a trusted client with years of service ahead of him. From the mid-1580s, when Herle was coming towards the end of his career, his potential utility was greatly diminished. The problems Herle experienced in exerting

\footnotetext{
102 Wallace T. MacCaffrey, 'Sir Christopher Hatton (c.1540-1591), ODNB, http://www.oxforddnb.com/view/ article/12605, accessed 11 May 2010.
} 
leverage over Cecil were exacerbated by the loss of trust which ensued after their argument in 1585. Cecil's willingness to go for months without contacting Herle demonstrated their unequal relationship. Herle's expansion of his patronage base to include Leicester and Walsingham also contributed to a shift in the dynamic between him and Cecil. While it made Herle less reliant on the benevolence of a single patron, it lessened his utility to Cecil by visibly dividing his loyalties.

These observations about Herle's patronage relationships provide wider insights into Elizabethan patronage. As was noted in the introduction, Herle was hardly a unique figure in the Tudor world, and much of what we have seen can likely be extrapolated to other minor civil servants and members of the gentry. Patronage was the glue that held Tudor society together. Herle's reliance upon Cecil's patronage to extricate himself from any number of situations demonstrates that the support of a powerful patron was vital to advancing oneself in the Tudor world. Similarly, it was only through Cecil's intervention that Herle could hope to gain recompense for his service and the promise of future rewards. The proximity of Herle's patrons to the Queen was instrumental in their importance to their clientele. So many of Herle's letters ask Cecil to intervene on his behalf with the Queen, because a large part of a patron's importance to his clients lay in his proximity to Elizabeth. Hatton and Leicester developed their clientage by exploiting the Queen's favour, and Cecil himself was not unwilling to do so. In exchange for the many benefits a client garnered from his patron, he was expected to perform equivalent services. Herle's abilities to gather useful intelligence and conduct negotiations in multiple languages were the primary currency he used to exert leverage over Cecil and his other patrons. The following chapters will examine how Herle held upheld end of the patron-client bargain. 


\section{Chapter IV: Herle in the Netherlands}

William Herle's work against the Ridolfi plot has generated far more historical interest than any other phase of his life, but his periods in the Netherlands had more influence on his career. At different times in his life, Herle served there as a negotiator, a financier, and a diplomat, while constantly sending information back to England. During the decade after the Ridolfi Plot, between 1573 and 1582, Herle spent much of his time in the Netherlands. He travelled back and forth between Antwerp and London repeatedly, and his letters describe diplomatic discussions with the Dutch one month and his financial dealings in England the next. There is evidence that a significant amount of Herle's correspondence from this period has been lost. In a letter of 18 May 1576 for example, Herle mentions 'the 1[ett]re that I shewed you that Powell Buis [Paul Buys] \& Ortell wrytt me.' Despite these gaps in Herle's correspondence, his involvement in negotiations between the Netherlands and England is one of the most interesting periods of his life, and shows how the English government utilised his Netherlands connections to inform their decisions.

Herle's letters provide ample evidence of how English foreign policy was conducted, utilising connected individuals such as Herle on an ad hoc basis, rather than negotiating through an established diplomatic corps. ${ }^{2}$ The problems this unsophisticated and decentralised approach caused Herle were shown above, in the form of his debts which increased significantly each time he was forced to pay his own way on a government posting. It was equally problematic for the government, with Herle and his peers not always proving up to the task of keeping Elizabeth and her councillors accurately and timely informed of overseas events. Despite Herle's mistakes in this area, most notably his premature report of William of Orange's death, English policy

\footnotetext{
${ }^{1}$ Herle to Cecil, 18 May 1576, BL MS Lansdowne 23, f.164r.

${ }^{2}$ Susan Doran, England and Europe in the Sixteenth Century, New York (N.Y.), 1999, p.4.
} 
makers still relied on the information he provided. This was because Herle was one of the few sources, if not the only source, they had on events in the Netherlands through much of this period. Policy makers were forced to rely on information that was often months out of date, and any source of news was appreciated, reliable or not.

The Netherlands were vital to English interests throughout the late medieval and early Tudor periods. English foreign policy was based upon the dual precepts of hostility towards France and friendship with the rulers of Burgundy. During Elizabeth's reign, however, practical and religious considerations slowly dissolved the TudorHabsburg alliance until outright war was declared against Habsburg Spain in 1583. The most important contributory factors to this dissolution can be summarised as: religious strife; competing territorial interests; and the sudden weakness of both sides' traditional enemy, France, all of which are reflected in Herle's letters. Henry VIII's decision to discard his Habsburg wife Catherine escalated tensions between England and Spain, although these were ameliorated by his daughter's marriage to Philip after his death. ${ }^{3}$ While this alliance seemed initially to restore the ancient amity between the houses, in retrospect it merely postponed long-term change.

England and Spain's main point of contention was their competing strategic interests in the Low Countries. Both sides saw the Netherlands as a natural extension of their sphere of influence: the English because of the London-Antwerp trade, as well as the threat that Holland and Zealand provided as natural bases for invasion of England through their deepwater ports and prevailing winds; the Spanish because of the hereditary position of the Habsburgs as rulers of the provinces, and the substantial wealth the Dutch and Flemish entrepôts and markets funnelled into Spanish hands. ${ }^{4}$ This strategic conflict was exacerbated by increasing religious extremism on either side.

\footnotetext{
${ }^{3}$ Doran, Elizabeth I and Foreign Policy, pp.2-4.

${ }^{4}$ ibid., p.11.
} 
During Elizabeth's reign, England slowly but clearly became a Protestant nation, while Philip II sought to impose Catholic uniformity in the Netherlands. Although revisionist historians such as Christopher Haigh have argued that England remained overwhelmingly Catholic well into the Elizabethan era, it is clear that for the majority of her reign those in a position to influence foreign policy were convinced Protestants. ${ }^{5}$ Elizabeth's right to the throne was based upon the legality of Henry's divorce from Catherine, necessitating a certain degree of Protestantism on Elizabeth's part, and the Queen's ego benefited from her claim to hold both temporal and spiritual power. ${ }^{6}$ However Elizabeth's love for ritual made her loathe to abandon some of the formal aspects of Catholicism, and she preferred private prayer over the public sermons so popular amongst Protestants. ${ }^{7}$ Given her religious ideas and the international complexities, the Queen was often of two minds, a state which encouraged her advisors to attempt to persuade her to their own lines of thinking - in Cecil's case the nightmare vision of vast international Catholic conspiracy against her, which required a similarly unified Protestant world to counter it. ${ }^{8}$

With Protestantism dominating England, and Catholicism doing likewise in Spain, there was a significant proportion of English Privy Councillors who felt that they needed to align themselves with fellow Protestants in the Germanic states and the Low Countries. ${ }^{9}$ This way of thinking was exemplified by the Earl of Leicester, but shared by Cecil, Walsingham, and other councillors to varying degrees. This idea of Protestantism as a pan-European ideological and religious alliance, often referred to as the "Protestant Cause," was seen as the natural counterpoint to the international Catholic conspiracy described in Chapter II. While ideologically sound, an alliance

${ }^{5}$ Christopher Haigh, English Reformations: Religion, Politics, and Society under the Tudors, Oxford, 1993, pp.235, 246-7, 293-5.

${ }^{6}$ ibid., p.237.

7 Patrick Collinson, 'Elizabeth I (1533-1603), $O D N B$, http://www.oxforddnb.com /view/article/8636, accessed 11 May 2010.

${ }^{8}$ Lake, 'A Tale of Two Episcopal Surveys,' pp.154-155.

${ }^{9}$ Doran, England and Europe, p.7. 
based upon confessional similarities proved difficult to implement in reality. English diplomats had failed to establish ties to the Lutheran princes of North Germany and Scandinavia, largely due to their own ineptitude. English agents demonstrated a remarkable lack of understanding about German politics, treating the many princes as a single group and ignoring differences between them. ${ }^{10}$ Having ruined any chance they had with German Protestants, those in the Netherlands were the last ally that radical English Protestants felt they could rely on. Herle seems to have been a believer in the Cause, and it is in his attitudes towards the Netherlands that we can see much of his world view expounded.

\section{The Protestant Cause}

On 11 June 1573, Herle composed a lengthy report on the Netherlands situation. The importance of this document is emphasised by the fact that it survives in three copies, one in the State Papers, and two in the Cotton manuscripts. ${ }^{11}$ Herle described it as 'certaine discourses which the Prince of Orenge had with me,' and it focused on the need for England to support the Dutch against the Spanish. This idea would become a rallying cry for the Cause, and indicates that Herle was associated with aggressively radical Protestants, and could have been one himself. At the time Herle wrote this letter, the Queen was indisposed towards aiding the Dutch directly. Elizabeth's public stance was that Orange and his supporters were "no better then rebells to their K[ing]. ${ }^{12}$ This did not prevent those who believed in the Cause from attempting to persuade her to share their view.

Herle highlighted several reasons why England should intervene in favour of the Dutch, all of which mirror ideas modern historians have postulated as catalysts for intervention. He argued that Philip ultimately planned to attack England, 'wanting only

\footnotetext{
${ }^{10}$ ibid., p.95.

${ }^{11}$ Herle to Cecil, 11 June 1573, TNA SP 70/127/36, ff. 173r-184v; BL Cotton Galba C IV, ff.381r-388v; BL Cotton Titus F III, ff.295r-301v.

${ }^{12}$ TNA SP 70/127/36, f.178v.
} 
th'opportunitie of tyme to see those troubles of Fraunce and of the Lowe Countries once ceassid, the easlier then and with more advauntage to atcheive his purpose. ${ }^{, 13}$ The threat to invade England, Herle wrote, had been 'hearde and observid even from the K[ing] of Spaines owne mowthe' Furthermore, the fates of England and the Low Countries were closely intertwined. The sea passage from Spain to the Netherlands ran through English waters, making it a vital strategic area for Philip if he expected to reintegrate the entire Low Countries into his empire.

Herle supported these strategic reasons for allying with the Netherlands by emphasising the danger posed by international Catholicism, claiming that the Pope and Philip were working together to encourage sedition within England. This was obvious, Herle claimed, as the Catholic nations intended the 'utter ruyn and rooting upp of all those of the reformid religion,' amongst whom the 'English Nation kepe the first place. ${ }^{14}$ While Philip's relationship with the papacy was often turbulent, in the 1570 s their interests intersected sufficiently to form a close alliance. ${ }^{15}$ Philip himself was deeply religious, pursuing what Geoffrey Parker has termed "messianic Catholicism," in which Philip considered his personal agenda synonymous not only with that of Spain, but of God. ${ }^{16}$ Herle emphasised the religious aspect of the expected conflict between Spain and England, claiming that Philip thought of English Protestants 'with an immortall hatred never to be reconciled. ${ }^{17}$

Herle's focus on the religious nature of the Franco-Spanish alliance against England and the Netherlands was complemented by a subtle domestic Catholic conspiracy to subvert Protestant rule in England. Herle claimed that Philip and Mary, Queen of Scots, conspired to take Elizabeth's throne. 'Beholding that there is no yssue

\footnotetext{
13 ibid., f.174r.

14 ibid.

${ }^{15}$ Parker, The Grand Strategy of Phillip II, pp.80-81.

16 Geoffrey Parker, 'The Place of Tudor England in the Messianic Vision of Philip II of Spain,' Transactions of the Royal Historical Society, Sixth Series, Vol.12, 2002, p.173.

${ }^{17}$ TNA SP 70/127/36, f.174v.
} 
of her Majesties bodye to succede in the Realme after her,' the Spanish King encouraged internal dissent to weaken all other claimants, 'then by some newe allyaunce' with Mary would 'assure him selfe of the whole state for ever. ${ }^{18}$ This internal disintegration would be aided by 'Englishe Papists which are not a fewe in number,' who, inspired by Catholic success in the Low Countries, would 'desier and hope for a like alteracon at home.'

In order to overcome this two-pronged Catholic attack on England, Herle recommended that Cecil advise the Queen to support the Netherlands against Spain. If the 'lowe Countries [could] be strengthenid and countenanced to holde oute then is it a thinge assured that the Spannyards shall...loose their longing for making an invasion in Englande.' ${ }^{19}$ Elizabeth, said Herle, should 'take theim into her protection and defend their comon cause of religion and libertie against the Tyranny of Spaine and the bloudy devices of Rome,' referencing his belief in the zealous Protestant Cause.

Herle's focus on religious solidarity combined with strategic necessity shows how the ad hoc appointment of connected individuals such as Herle undermined England's long term diplomatic interests in Europe. Rather than representing Elizabeth's interests, he was clearly siding with her more zealous councillors who argued for intervention in the Netherlands. This bias was only to be expected, given that Herle's position overseas was largely due to these same councillors' influence, but made for an inconsistent diplomatic service which could not be relied upon to feed unbiased information back to the Queen. Herle's letter reads more like an advert for the Cause than it does a balanced view of the Netherlands situation. With policy makers basing their decisions on this sort of information, it is no wonder that Elizabeth was notoriously indecisive.

\footnotetext{
18 ibid., f.175v.

${ }^{19}$ ibid., f.176v.
} 
Herle's partiality was not only tied to his belief in the Cause, but also to his association with Dutch politicians. While the letter detailed above implies that Herle was working with Orange himself in 1573, it was Herle's association with Orange's representative in London, the Dutch politician Paul Buys, which was most indicative of his divided loyalties. Orange's representatives had offered Elizabeth the sovereignty of Holland and Zealand as early as 1573, when the Spanish advance towards Flushing left them in a dire situation. ${ }^{20}$ When the Queen refused, the offer languished until September 1575 when the Spanish financial collapse and consequently faltering military push within the Netherlands gave Orange hope that the war could be won with English assistance. Orange's ambassadors discussed the transfer of sovereignty to Elizabeth with the English Privy Council in January 1576, but both Councillors and the Queen balked at provoking Spain by openly contesting Philip's title. Councillors placed the issue before the Parliament which opened in February, but Hatton and his pro-Habsburg allies successfully blocked Leicester's attempts to use parliamentary opinion to push the Queen into accepting Dutch sovereignty. ${ }^{21}$

In March 1576 Herle became involved in this ideological struggle, representing Buys' interests to Cecil and Elizabeth. Herle and Buys attempted to defuse a diplomatic bombshell which threatened to end any chance of Elizabeth taking sovereignty of the Netherlands. A group of Sea Beggars, pirates operating under William of Orange's letters of marque, had kidnapped the Portuguese ambassador's fiancé during a naval altercation near Dover. ${ }^{22}$ The ambassador's fiancé had been under Elizabeth's protection as she crossed from Calais to Dover, and the incident infuriated the Queen

\footnotetext{
${ }^{20}$ Glyn Parry, 'John Dee and the Elizabethan British Empire in its European Context,' The Historical Journal, Vol.49, No.3, Sep. 2006, p.660.

${ }^{21}$ ibid., pp.660-661.

${ }^{22}$ Herle to Cecil, 6 March 1576, TNA SP 70/137/53, ff.192r-193v; Herle to Cecil, 7 March 1576, TNA SP 70/137, ff.194r-194v; these letters have previously been misdated as 1575 , but their content places them clearly in the following year.
} 
who promptly ordered the seizure of all Zealand ships in English ports. ${ }^{23}$ Herle and Buys claimed that the 'pore men of Holland' had never intended to kidnap the ambassador's fiancé, and were merely retaliating against the Portuguese who had thrown their men overboard. ${ }^{24}$ The Dutch wished to 'intertayne good amitye with the K[ing] of Portingalle \& all his subjects' despite this blunder.

Cecil's response does not survive, but when Herle reported Buys' rejoinder a few days later, he showed how his own opinions on the matter differed from the Lord Treasurer's. Buys was told that the English thought that the Dutch had not been provoked, and 'rather lykely that the Flusshingers dyd lye purposely in awaytt there for those shippes,' essentially an accusation of piracy by Cecil. Herle passed on Buys' response that the accusations were 'malycyously practised' lies, and himself suggested that Elizabeth 'appoint on or ij suffycyent dyscrete persons to be resydent for her in Holland \& Zeland' to investigate the charges and similar incidents and report back to the Crown. ${ }^{25}$ Presumably Herle intended that he should be one of these appointees, but the diplomatic situation with Spain made this idea untenable. Sending representatives to the Dutch would have been tantamount to Elizabeth awarding the Dutch diplomatic recognition, a fact which Herle must have been aware of to some degree.

Herle's inability to correctly represent Cecil and Elizabeth's interests in the Dutch conflict is further shown by a letter of 14 March 1576 in which he claimed:

Itt is given owtt verey malicyously amongst gentillmen \& sowdyers, \& amongest those of good sort that proffesse the Relygion that your L[ordship] hath bin the only lett \& overthrowe of this Holland service, disswading her majestie from the enterprise, where otherwise the Erlles of Lecester \& Sussex, were ernest favorers \& furtherers of ytt. ${ }^{26}$

Cecil rightly saw this as an attack on his lack of support for the Cause, and must have both indicated his displeasure at this impertinence and explained his need for

\footnotetext{
${ }^{23}$ MacCaffrey, Queen Elizabeth and the Making of Policy, p.206.

${ }^{24}$ TNA SP 70/137, f.194v; TNA SP 70/137/53, f.192r.

${ }^{25}$ TNA SP 70/137/67, f.206v.

${ }^{26}$ Herle to Cecil, 14 March 1576, TNA SP 70/137/85, ff.220r-220v.
} 
dissimulation. In Herle's next letter he was eager to tell the Lord Treasurer that he had 'Pawll Buiz understand, of that good estymatyon that yow have him in, \& of the good that ye wysshe unto the cawse,' despite needing to 'gyve theme hard words accordyng to the allteracyon that tyme, partyes, $\&$ occasyons dyd minister. ${ }^{27}$

Herle's explanation of Cecil's actions allows us to see how the Lord Treasurer was successfully playing both moderate and radically Protestant sides in the debate over intervention in the Netherlands. While Cecil did not want to take action against the Dutch, strengthening the international Catholic conspiracy he feared in the process, he recognised the need to publicly align his opinion with Elizabeth's. Cecil pretended to share the Queen's anger at the Dutch pirates while using Herle to secretly assure the Dutch of his friendship behind her back. Walsingham, similarly worried that this incident would undermine the Cause, spent the next few months coaching Orange on the intricacies of negotiating with Elizabeth. ${ }^{28}$ Herle did not practice this level of dissimulation, clearly aligning himself with both the Cause and the Dutch politicians whom aggressive English Protestants wished to aid against Spain.

In the late 1570s, English involvement in the Netherlands became embroiled with Elizabeth's protracted series of marriage negotiations with the French Duke of Anjou, generally referred to as the "Anjou Match." ${ }^{29}$ While Cecil and the Earl of Sussex were vocal supporters of the marriage, noting that it would strengthen England's international position considerably, Leicester, Walsingham and the other firmly Protestant councillors opposed it, raising Anjou's Catholicism and the fear of a Valois on the English throne as concerns. Elizabeth's opinion on the marriage changed during the 1570s. When it was first broached in 1572 she emphasised the differences in age

\footnotetext{
${ }^{27}$ Herle to Cecil, 15 March 1576, TNA SP 70/137/85, f.222r.

${ }^{28}$ Parry, 'John Dee and the Elizabethan British Empire,' p.657.

${ }^{29}$ Francis, Duke of Anjou, was known as Alençon until 1576, when his elder brother Henri became King of France. Henri had previously also been the Duke of Anjou and had similarly entered marriage negotiations with Elizabeth, although these seem to have been far less serious than those with his younger brother.
} 
and religion between herself and Francis, but kept negotiations open to maintain diplomatic channels. ${ }^{30}$ By 1579, however, Elizabeth had shifted from what Susan Doran has termed "matrimonial diplomacy" to seriously considering the proposal. ${ }^{31}$ In the end she only backed down in the face of popular hostility to a Catholic marriage. ${ }^{32}$ However, the Anjou match, alongside Philip's capture of Portugal, proved significant in refocusing Elizabeth on the dangers of Spanish expansionism.

In March 1581 Herle was commissioned by Cecil and Leicester to negotiate with Orange in Antwerp, where he passed on Leicester's messages, 'intertayneng the best offices I cowd betwen yow bothe. ${ }^{33}$ Herle discussed Anjou's arrival in the Low Countries, and his negotiations with the States to accept him as their sovereign. Anjou and the States General signed the Treaty of Plessis-les-Tours, awarding him the title "Protector of the Liberty of the Netherlands," in September 1580, but the treaty would not become official until the Estates repudiated Philip as their sovereign. ${ }^{34}$ This took until July of the following year, and Herle was sent to report on the process.

Herle's bias in favour of the Cause came to the fore again in these letters, with the addition of a personal distaste for the French Catholic Anjou. In March 1581 Herle revealed to Leicester the disagreement between Anjou and the Dutch over his maintaining his Catholic religion in an overwhelmingly Protestant state. ${ }^{35}$ Similar issues were concurrently being raised in England in response to Anjou's marriage suit, and this is unlikely to be a coincidence. John Stubbes' book Discourie of a Gaping Gulf VVereinto England is Like to be Swallovved by Another French Marriage brought many of these arguments into the public forum, but received a furious response from the

\footnotetext{
${ }^{30}$ Susan Doran, Monarchy and Matrimony: The Courtships of Elizabeth I, London, 1996, pp.133-138.

31 ibid., p. 154.

32 ibid., pp.169-176.

${ }^{33}$ Herle to Leicester, 3 March 1581, TNA SP 83/15/36, f.71r.

${ }^{34}$ Geoffrey Parker, The Dutch Revolt, Revised ed., London, 1985, p.197.

35 ibid., f.71v.
} 
Queen, who declared it the work of a seditious libeller. ${ }^{36}$ By 1581 Leicester had realised he needed to accept the Anjou Match in order to ensure England was not left isolated, but there is no evidence Herle felt the same. ${ }^{37}$ Having spent much of his time in the Netherlands, he could have been unaware of Leicester's change of heart, and thought this news would allow the Earl to raise the issue in Elizabeth's mind without directly insulting her as Stubbes had.

Herle's own dislike for Anjou came across strongly in these letters, a fact which clearly influenced his depiction of events. He portrayed Anjou as a Catholic mercenary, demanding freedom of worship as well as ' 300,000 gylldernes by the monethe' from the States to pursue the war against Spain. Herle further opined that the French Wars of Religion were advantageous for England, and that he hoped Anjou would be sucked back into them as a French Netherlands would 'be a nere peril unto England. ${ }^{38}$ As Elizabeth fully supported Anjou by this point, Herle was clearly at odds with his Queen in making his dislike of Anjou shown. This also indicates how out of touch with domestic politics Herle could become on his extended overseas missions, making antiFrench arguments that were no longer tenable in the tense international climate.

\section{The Orange Assassination Attempt}

Herle's biases and the choices he made about what information to send back to England could have drastic consequences for English foreign policy. The trust placed in Herle, and the problems this could cause, is exemplified by his premature reporting of William of Orange's assassination in 1582. Herle reported that on 18 March the Prince had been attacked by an assassin who got close to Orange then 'sodaynlye discharged a

\footnotetext{
${ }^{36}$ John Stubbes, The Discouerie of a Gaping Gulf VVereinto England is Like to be Swallovved by Another French Marriage, if the Lord Forbid Not the Banes, by Letting Her Maiestie See the Sin and Punishment Thereof, London: H. Singleton, 1579, STC 23400, A3v; 'Denouncing Stubbs' Book, the Discouerie of a Gaping Gulf,' 27 September 1579, 21 Elizabeth I, reproduced in Paul L. Hughes and James F. Larkin (eds.), Tudor Royal Proclamations: Volume II, The Later Tudors, 1553-1587, New Haven (Conn.), 1969, pp.445-449.

${ }_{37}^{37}$ Doran, England and Europe, p.74.

${ }^{38}$ Herle to Cecil, 18 March 1581, TNA SP 83/15/68, ff.150r-150v.
} 
pistoll (that he helld unsene) att the prince. ${ }^{, 39}$ Luckily the firearm's recoil sent the bullet off course through the Prince's cheek without causing serious damage, 'a provyden[ce] of God most admirable' as Herle commented. Orange's bodyguards inflicted thirtythree 'mortall wowndes' on the assassin, despite the Prince's cries to take his attacker alive.

According to Herle, reports that Orange had died reached Antwerp, where a mob of townsmen immediately threatened Anjou, 'the frenche, $\&$ the papists...that not on of theme sholld be lefte alive. ${ }^{40}$ The army, reassured that Orange was alive and that the assassin was Spanish not French, suppressed mob action and defended Anjou's lodgings. While Herle's dislike of Anjou came across strongly in his previous letters, the Duke's actions in the aftermath of the assassination attempt seem to have endeared him to Herle. On 25 March, Herle related Anjou's plans to tell the 'Imperyall dyett, \& the Kyngs \& princes of Christendom' about Philip's responsibility for the assassination attempt, and warn them likewise to beware. ${ }^{41}$ Philip and his ministers had sponsored various assassination attempts against Orange throughout the revolt, expecting that without his personal leadership and charisma Dutch resistance would founder. ${ }^{42}$ Faced with Anjou's leadership in a time of crisis, the States swore 'to holld hym \& obeye hym, as their Soverayne. ${ }^{43}$ Anjou in turn promised protection and to maintain their 'privylegs' subverted by Philip. Herle approved, for though 'Holland \& Zeland made difficulties' about swearing allegiance to a foreigner, they eventually 'agreed with the rest \& made their othe. ${ }^{44}$

Although Herle's distaste for Anjou was ameliorated by the Duke's actions, bringing his interests closer to those of Elizabeth, his ability to perform his duties in the

\footnotetext{
${ }^{39}$ Herle to Leicester, 20 March 1582, BL MS Cotton Galba C VII, f.205r.

40 ibid.

${ }^{41}$ ibid., ff.208r-208v.

${ }^{42}$ Parker, The Grand Strategy of Philip II, pp.134-135.

${ }^{43}$ Herle to Leicester, 31 March 1582, BL MS Cotton Galba C VII, f.211r.

44 ibid.
} 
Netherlands adequately was called into question a week later. Herle informed Leicester that Orange's wound had begun to bleed profusely after the torn scabrous tissue that had previously 'coverd som vayne that was hurte by the bullett' became detached. ${ }^{45}$ The doctors took extreme measures to preserve Orange's life, with servants taking turns applying pressure to the wound inside his throat. ${ }^{46}$

On 2 April 1582, Herle reported that Orange had taken a turn for the worse, losing 'more than 30 owncs of blood' when his wound reopened and his physicians gave him a week to live 'att the furthest. ${ }^{47}$ Herle therefore counselled Cecil to quickly ensure stability in the Netherlands, because without the Prince Anjou would not know what course to take. Herle recommended that the Queen re-examine her opposition to an alliance with Holland and Zealand. By joining with the Low Countries Elizabeth could 'brydell the K[ing] of Sp[ain],' and 'cownterpeyse the Frenche, yf they sholld exceede lymites. $^{48}$ Furthermore, Herle argued disingenuously, allying with these provinces would offend neither France, because of Anjou's agreement with the Dutch, nor Spain because Orange's provinces were not bound by the Pacification of Ghent.

By rushing to advise Cecil and Elizabeth, Herle left himself open to criticism when his news turned out to be incorrect. Almost a fortnight later, Herle wrote apologetically to Leicester of the Prince's recovery. While this letter is badly damaged and missing sections, Herle had clearly been severely rebuked for prematurely reporting Orange's death. Herle now admitted Orange was 'in no peryle att all. ${ }^{49}$ Herle had damaged his reputation with Elizabeth, who made her displeasure known. He had been warned not to announce things 'that nether were assured nor lykelye. ${ }^{50}$ Herle tried to claim that he had written, not knowing Orange would die, but fearing that Elizabeth

\footnotetext{
${ }^{45}$ ibid.

${ }^{46}$ Lisa Jardine, The Awful End of Prince William the Silent: the First Assassination of a Head of State with a Handgun, London, 2005, pp.72-74.

${ }^{47}$ Herle to Cecil, 2 April 1582, TNA SP 83/15/95, f.208r.

48 ibid., ff.208v-209r.

${ }^{49}$ Herle to Leicester, 14 April 1582, BL Cotton Galba C VII, f.226r.

${ }^{50}$ ibid.
} 
would be unprepared for the new situation if he did. On April 28, almost two months after the assassination attempt, Herle informed Walsingham that Orange had recovered. Herle had found him 'hable to walke in his chamber' and asking after Leicester, Cecil, and Walsingham's wellbeing. ${ }^{51}$

Despite his gaffe about Orange, Herle claimed to Leicester that 'I am well respected here, by myne own yndustrye,' and alleged that Anjou had offered him 'very good termes' to 'remayne yn this contry, gyveng me the credite to have accesse unto hym. ${ }^{, 52}$ However, Herle promised to 'dyrect non other cowrse, butt that which shall be prescribed me from your L[ordhsip]. ${ }^{53}$ Given Herle's continued credit issues in England, including his difficulties with the Waads, it exemplifies his negative assessment of Anjou that Herle would pass up this offer of financial security in the Low Countries. Loyalty to his Queen and his wish to remain close to his sister in England, might also have played into Herle's refusal.

This chapter has discussed Herle's role as informant about the increasingly important Netherlands. Herle's experiences show that the ad hoc nature of England's approach to foreign policy caused severe difficulties in practice. The Tudor state made use of "connected" individuals who sometimes were not up to the task of keeping Elizabeth promptly, fully, and accurately informed of developments overseas. As these men were often the government's only source of information about what occurred in Europe, this could have disastrous consequences. The Netherlands were vital to English strategic and economic concerns throughout the Tudor period, and the conflict there between Philip and his Dutch citizens was a central concern in the highest circles of English policy making.

\footnotetext{
${ }^{51}$ Herle to Walsingham, 28 April 1582, TNA SP 83/15/128, f.280v.

${ }_{53}^{52}$ Herle to Leicester, 22 April 1582, BL Cotton Galba C VII, f.230r.

${ }^{53}$ ibid.
} 
Privy Councillors such as Cecil and Leicester chose Herle as an intelligence gatherer and negotiator because of his connections in the Netherlands, most notably with Paul Buys and William of Orange. Yet although these connections made Herle invaluable, they also divided his loyalties. Herle's letters show how his own biases often factored into the reports and recommendations he made, particularly in his support of the Protestant Cause, the Dutch's right to rebel against Philip, and his dislike of Anjou. Furthermore, in his zeal to keep Elizabeth informed of major events in a timely manner, Herle sometimes overcompensated and moved into the realm of predicting rather than reporting events. This tendency was exemplified in Herle's disastrously premature report of Orange's death.

These observations about Herle's place in the English foreign service can be extrapolated outwards to wider observations about the inadequacies of Tudor foreign policy as a whole. Despite Herle's obvious biases and colossal mistakes, he retained his career in this area, and never seems to have been in true danger of losing his place. In fact, the next chapter details further sensitive work that Herle was trusted to undertake, most notably his embassies to East Friesland. This highlights the worrying possibility that if Herle was rewarded for such flawed service, perhaps he one of the better examples of this system in action. 


\section{Chapter V: The End of Herle's Career}

In 1583 Herle was recalled from the Netherlands, possibly a delayed response to his mistake over Orange's “death.” He again began uncovering conspiracies against the English government, especially the Throckmorton plot. This chapter will argue that Herle's involvement in this major Elizabethan conspiracy, has been mistakenly downplayed by historians, and that it significantly enhanced his career prospects by bringing him closer to Walsingham. Comparing Herle's reports to A Discouerie of Treason, the official version of the Throckmorton plot, shows that Herle's information was instrumental in uncovering the plot, and that the government edited this information for political reasons. Herle's success in uncovering the Throckmorton plot probably explains his appointment as ambassador to East Friesland to negotiate trade rights and block Spanish advances.

While his three embassies to East Friesland were undoubtedly a significant achievement for Herle, they proved devastating to his interminably shaky finances. The ineffective Elizabethan foreign service relied on ambassadors paying their own way, perhaps with a small stipend, and recouping losses upon their return when they were rewarded with offices, titles and pensions. Herle received none of these, perhaps due to his failure in the second embassy, his record of tarrying too long on assignment, and his poor future prospects due to sickness. Herle died in 1588, abandoned by his patrons and deeply in debt.

\section{The Throckmorton Plot}

The primary conflict between Protestantism and Catholicism in the 1580s, in the Low Countries, impacted on English politics much less than the sporadic outbreaks of violence in France. What made the conflict between the Protestant Huguenots and Catholic Guisards important was the existence of Mary, Queen of Scots. As heir 
presumptive to the English throne, and to some de jure queen of Scotland, Mary posed a unique danger to Elizabeth's regime. To Catholics, Mary symbolised their repression and persecution. To Protestants she threatened a return to the pyres of "Bloody Mary's" reign. As first cousin to the Duke of Guise, many Englishmen held Mary responsible for the massacre of Protestants on St Bartholomew's Eve in 1572.

Mary's political significance was eclipsed throughout the 1570 s by the English attempt to consolidate the two kingdoms' interests through the Anjou Match. By 1583 these negotiations had broken down, partly because of intense opposition to Anjou's Catholicism. Since Elizabeth would now die childless, Mary represented a greater danger to Protestant England. Cecil had failed to push Elizabeth into executing Mary for the Ridolfi plot. He had been forced to settle for Norfolk's head. Yet the intervening years had only confirmed Cecil's conviction that Mary posed a mortal threat to him and his queen. With Cecil now Lord Treasurer and Walsingham Secretary, two of the most powerful men in England saw Mary as the single greatest threat to the regime's security.

Cecil exposed Mary's continued involvement in conspiracies to overthrow Elizabeth during what is generally called the Throckmorton plot, named after Francis Throckmorton, who was publicly tried as the ring-leader. Together with Sir Francis Englefield in the Low Countries, and Thomas Morgan in France, Francis Throckmorton formed what Stephen Alford has dubbed a 'spidery network of conspirators.' Throckmorton acted as part advisor, part messenger, relaying letters between Morgan, Englefield, the French and Spanish ambassadors, and Mary. Walsingham's organised surveillance of the French embassy had first made him and Cecil aware of the conspirators. Like his success in the Ridolfi plot a decade earlier, Herle played a key role in this enterprise. By now he was one of the more experienced government intelligencers, a natural choice to aid in Walsingham's infiltration of the French

\footnotetext{
${ }^{1}$ Alford, p.254.
} 
embassy. His earlier success, as well as his common reputation as Cecil's servant, meant that Herle took a less direct role in uncovering the Throckmorton plot. His contribution, nonetheless, was vital.

\section{Surveillance of the French Embassy}

Herle maintained his interest in Low Countries affairs, but for most of 1583 he was stuck in London, perhaps due to his unpaid debts. He stayed in close contact with Cecil, but worked mostly with Walsingham. This was partly because when Walsingham's moved into Cecil's former position as Secretary, he became de facto spymaster. A more significant factor, however, was Walsingham and Cecil's morbid fear of Mary. This obviously entailed surveillance on prominent Catholics in London, particularly those connected to the Queen of Scots. Herle's considerable experience such work made him an obvious choice for Cecil to recommend to Walsingham. The Secretary may not have been entirely comfortable trusting Herle, undoubtedly Cecil's man, and this probably explains Herle's less "hands on" role in the operation. Throughout the unravelling of the Throckmorton plot, Herle supervised Walsingham's own spies, reporting to the Secretary. Walsingham needed to maintain a certain distance from his agents, because their primary target was the French embassy, a suspected hotbed of pro-Marian activity.

In late April 1583, Walsingham's spy in the embassy informed him that 'someone called Herle came to our house.' ${ }^{2}$ Although the spy's tone indicates he considered this visitor unimportant, Herle's name probably alerted Walsingham that Cecil's operations were overlapping with his own, so the Secretary contacted Cecil to organise a joint surveillance operation. John Bossy has described Michel de Castelnau, Henri III's ambassador to Elizabeth's court as 'a genial and civilised man...genuinely

\footnotetext{
${ }^{2}$ Henry Fagot to Walsingham, 22-25 April 1583, TNA SP 78/9, ff.216r-217v, original in French translated and reprinted in Bossy, Giordano Bruno, pp.193-196.
} 
interested in England and the English... who got on with Elizabeth and her councillors.' ${ }^{3}$ Castelnau was therefore somewhat of a rarity amongst ambassadors to England, especially by comparison with his Spanish counterpart Don Bernardino de Mendoza, who frequently clashed with courtiers, and treated the English as hopelessly provincial heretics. ${ }^{4}$ Castelnau's political influence at court had waned since its zenith during the Anjou marriage negotiations a few years earlier, and his focus had gradually turned to working for Mary's release. ${ }^{5}$ He hoped that a free Mary, under French control, would restore France's former ties with Scotland. Her role as presumptive heir would not have escaped him.

Between 18 and 20 April 1583, Walsingham received several letters, signed "Henry Fagot," from Salisbury Court, reporting visitors and events at the house. Castelnau kept an intellectual table at his embassy in Salisbury Court. ${ }^{6}$ One house-guest was Giordano Bruno, the Neapolitan author, philosopher, and poet. A lapsed priest in exile, Bruno used his considerable social skills to make himself welcome at many European courts. ${ }^{7}$ Around 13 April 1583, he arrived at Salisbury Court, carrying a letter from Henri III ordering Castelnau to take him into his household. ${ }^{8}$ Bossy has convincingly argued Fagot was Bruno. From the timing and content of Fagot's letters, Bossy concluded that he was 'an Italian priest of anti-papal convictions.' ${ }^{9}$ No evidence of Fagot exists before or after this period. Peter Costello has argued that Bossy's argument consists entirely of persuasive yet circumstantial evidence, but this chapter accepts Bossy's argument. ${ }^{10}$

\footnotetext{
${ }^{3}$ Bossy, Giordano Bruno, p.9.

${ }^{4}$ MacCaffrey, Queen Elizabeth, pp.315-316.

${ }^{5}$ Bossy, Under the Molehill, pp.7-8.

${ }^{6}$ Bossy, Giordano Bruno and the Embassy Affair, New Haven (Conn.): Yale University Press, 1991, p.12.

${ }^{7}$ ibid., p.140.

8 ibid., p.98.

${ }^{9}$ ibid., 1991, pp.19, 75-76.

${ }^{10}$ Peter Costello, 'Review of Giordano Bruno and the Embassy Affair,' Studies: An Irish Quarterly Review, vol.81, no.321 (Spring 1992), p.126.
} 
Fagot's letters described the ambassador dining with 'M. Throckmorton,' who had 'recently sent the Queen of Scots' $£ 300 .{ }^{11}$ A wealthy young gentleman from a Catholic family, Throckmorton's association with Mary's supporters seems unsurprising. Similarly 'Milord Henry [Howard], a Roman Catholic and Papist' came to the house that night to speak with the ambassador. Fagot also reported Herle's arrival at the embassy. ${ }^{12}$ Conversing with Castelnau in Italian, Herle told the ambassador that 'he knew very well that [the English] were trying to make the French believe a lot of rubbish, but they were mistaken in thinking that the French would swallow it. ${ }^{13}$

Fagot also noted that Herle was 'an agent for the ambassador, but does not trust him. ${ }^{14}$ The phrasing is ambiguous about who did not trust whom, and Bossy follows the strict reading that Herle did not trust the ambassador, but the logical assumption would be that the ambassador did not trust Herle. ${ }^{15}$ By now Herle's affiliation with Cecil was well known, ruling out the double-cross that he managed by befriending Bailey during the Ridolfi plot. From Fagot's report, it seems that Herle was trying to impugn the veracity of previous intelligence the French had received from some Englishmen. What this information was, we have no way of knowing, although it may have come from sympathetic Catholics, since Herle informed Castelnau that 'he was sure the Kings of Spain and France would put an end to all this nonsense,' suggesting that he was likely discussing an alliance between these two powers.

Herle was at least partially vindicated later the same day, when a representative of the Spanish ambassador visited Castelnau, and indicated that an agreement between the French and Spanish monarchs could be reached. ${ }^{16}$ Amicable communication

\footnotetext{
${ }^{11}$ Henry Fagot to Walsingham, 18-19 April 1583, BL MS Cotton Caligula C VII, f.214v, original in French translated and reprinted in Bossy, Giordano Bruno, pp.189-192.

12 TNA SP 78/9, ff.216r-217v.

13 ibid.

14 ibid.

15 'Nottez quil est facteur de monseigneur lambassadeur et ne ce fie gueres en luy' is the exact wording; ibid.

16 ibid.
} 
between Mendoza and Castelnau significantly improved their previous relations, as Mendoza rabidly opposed the Anjou marriage in which Castelnau had invested so much effort. ${ }^{17}$ This changed relationship between the ambassadors alarmed the Queen and her councillors, who feared a Franco-Spanish alliance. By 1584, Castelnau could write to Mary that Elizabeth 'has never been so suspicious of everybody or so nervous for her estate as she is at present, now fearing the king of Spain, now the king [of France], sometimes both together. ${ }^{18}$ Henri and Philip's interests were beginning to intersect around Mary and the restoration of Catholicism. The belief that Castelnau and Mendoza were actively collaborating with the Queen of Scots' supporters to bring this about crystallised over the next few months.

In mid-June Fagot assured Walsingham that 'the chief agents for the Queen of Scots are M. Throckmorton and Lord Henry Howard,' who only ever visited Castelnau at night. ${ }^{19}$ Furthermore, he informed Walsingham that he had 'made the ambassador's secretary so much my friend that, if he is given a certain amount of money, he will let me know everything he does. ${ }^{20}$ Notably, the secretary offered Fagot Castelnau's correspondence with Mary, allowing Walsingham to alter its contents and reseal it before Mary was any the wiser. The identity of the secretary who passed information to Fagot remains unknown, but it is unlikely Herle had direct contact with him. Herle's surviving letters only detail meetings with Fagot, and he may have had no idea who the mole in the embassy was.

Bossy speculates that Herle and Fagot's relationship began during the summer of 1583, sometime between May and August. ${ }^{21}$ By November 1583 they were certainly working together, as Herle sent Cecil a letter informing him, from Fagot, of the

\footnotetext{
${ }^{17}$ Bossy, Under the Molehill, p.60.

${ }^{18}$ Castelnau to Mary, April 1584, BL MS Harleian 22, f.3r-4v; cited in Bossy, Under the Molehill, p.83.

19 Bossy, Giordano Bruno, p.197, dates this letter 20-31 May. By John Bossy, Under the Molehill, pp.157-169, he amended it to 16-20 June. This thesis accepts Bossy's later date.

${ }^{20}$ Henry Fagot to Walsingham, 16 June 1583, TNA SP 53/12, ff.152r-153r, original in French translated and reprinted in Bossy, Giordano Bruno, pp.197-200.

${ }^{21}$ Bossy, Giordano Bruno, p.26.
} 
movements of various persons at the embassy. ${ }^{22}$ The reason for this sudden detail was probably the recent arrests of Edward Arden and John Somerville, the latter having been captured on his way to London, where he planned to kill Elizabeth. The threat of assassination panicked Cecil and Walsingham into springing the trap on the Throckmorton conspirators prematurely, as they feared the two plots were linked. In preparation for rounding up those involved in the Throckmorton plot, Cecil probably asked Herle for an update on those who were visiting Castelnau.

Herle described two conspirators, 'Archeballd Duglasse \& Kithe,' as having 'pryvate confference secrettly together. ${ }^{23}$ Herle particularly recommended that Douglas 'be looked unto, for he is a very practiser of the Scottish Q[ueen's] factyon, \& yett ynsynuates himsellf into an oppynion of her majesties service. ${ }^{, 24}$ Herle claimed that Douglas had 'dellt coninglye with som men of good sorte,' and tried to bribe him recently, 'presumyng belyke that I had neede' of ready money. While Herle was certainly not the most honourable man in London, it seems unlikely that he would betray Cecil and his Queen. More probably, Herle included this detail to enhance the authenticity of his intelligence by emphasising that it was first-hand, and to subtly remind Cecil of his pressing debts.

Bossy has argued that Fagot provided the substance of this letter, but it reflects Herle's method of tailoring his information to Cecil's prejudices. ${ }^{25} \mathrm{He}$ spent an entire page reinforcing Cecil's fears of the international Catholic conspiracy, although the 'D[uke] of Gwise' rather than Philip was the 'director of the action. ${ }^{26}$ Guise planned to marry Mary to an unnamed Catholic, to have England conferred upon him by the Pope, 'so as she [Mary] shall nott be establisshed esteemed Q[ueen] by her own right \& pretensyons, butt meerely by the Popes collucyon.' This describes what became known

\footnotetext{
${ }^{22}$ Herle to Cecil, 15 November 1583, BL MS Lansdowne 39, ff.189r-192v.

${ }^{23}$ ibid., f.190r.

24 ibid., f.190v.

${ }^{25}$ Bossy, Giordano Bruno, pp.28-29.

${ }^{26}$ BL MS Lansdowne 39, f.190v.
} 
as the Throckmorton plot reasonably accurately, and was Cecil's first concrete information about it.

\section{Herle and the Howards}

The most likely candidate for the anonymous Catholic was Henry Howard, the executed Duke of Norfolk's younger brother. Herle seems to have held a grudge against him. His brother's execution left Howard the senior member of the most powerful conservative family in southern England. Herle repeated the popular rumour that Howard was 'supposed to be a preest,' and 'in the secrett register of the popes cardynalles. ${ }^{27} \mathrm{He}$ informed Cecil that a relative of Howard's had 'receved $1[\mathrm{ett}] \mathrm{res} \&$ reliqwes from beyond the seas,' indicating contact with exiled Catholics as well as the papacy, and 'hath att this present a notable Jesuite desgysed in his service.' Herle did not name this disguised Jesuit, although in the margin next to 'a notable Jesuite' he scribbled 'among all the Jesuites,' indicating his importance in that order. Unfortunately Herle felt this identity too important to trust to writing, and promised to 'secrettlye \& faythfylly' advertise Cecil in person. ${ }^{28}$

Bossy has claimed that these attacks on Howard came 'undoubtedly from Fagot,' but Herle is the more likely source. ${ }^{29}$ Nothing said about Howard was exclusive knowledge to those living in the embassy, and while Fagot had no special reason to hate Howard, Herle had been intimately involved in Norfolk's downfall. While the Howards' power had been greatly diminished by their leader's execution, they remained a political force, and Henry Howard would have welcomed any chance to redeem his family's name at Cecil and Leicester's expense. Herle had been around the court and in Cecil's service long enough to understand these power dynamics. He would be far more willing

\footnotetext{
${ }^{27}$ ibid., f.191r.

${ }^{28}$ ibid., ff.191r-191v.

${ }^{29}$ Bossy, Giordano Bruno, p.29.
} 
to see treachery in Howard's smallest misstep than would Fagot, an Italian priest who barely spoke English and spent the majority of his time in the embassy.

Similarly Herle elaborated on Francis Throckmorton's activities. Herle 'advertised master secretorye this last somer' about Throckmorton's involvement with the Catholics in the French embassy. ${ }^{30}$ Although the original letter to Walsingham has not survived, he summarised it for Cecil. Throckmorton had 'long \& pryvat conferencs' with the ambassador 'att seasons suspyceows,' and participated in 'masse their att severall tymes.' Herle concluded that Throckmorton was 'very busy $\&$ an enemye to the present State.' Furthermore, Throckmorton's kinsman, Arthur Throckmorton, had dined with Castelnau, and his brother Thomas planned to leave England shortly with someone named Digby. Thomas Throckmorton and Digby were both 'papists \& noted of to carye yll \& busy myndes.' In a few short paragraphs, Herle built up a picture of the Throckmorton family as a hotbed of Catholic resistance. When placed alongside his information about Howard and the Jesuits, Herle made a strong case for the corruption of England's some of leading families by Papal, French, and Marian agents. With such information arriving on their desks on a near daily basis, little wonder that Cecil and Walsingham tended towards paranoia.

The day after this long letter, Herle wrote to Cecil about Howard again. This time he attacked Howard's 'booke agaynst prophesyes,' which Herle claimed contained 'sondry heresyes \& spyces withall of Treson.'31 'Som lerned man...of good judgement,' who were 'asswell qwalleffyed in state cawses, as devynitye' had so judged it. ${ }^{32}$ Herle cited the opinions of experts to impress upon Cecil that Howard's work was subversive.

\footnotetext{
${ }^{30}$ BL MS Lansdowne 39, f.191v.

${ }^{31}$ Herle to Cecil, 16 November 1583, BL MS Lansdowne 39, f.193r; Henry Howard, A Defensatiue against the Poyson of Supposed Prophesies, London: John Charlewood, 1583, STC 13859.

${ }^{32}$ BL MS Lansdowne 39, f.193r.
} 


\section{Howard \& Throckmorton's Arrests}

Between 16 and 20 November, Francis Throckmorton and Henry Howard were arrested. ${ }^{33}$ These arrests were premature, prompted by Arden and Somerville's arrests as noted above, and some of the conspirators escaped to write Leicester's Commonwealth, attacking the Earl but leaving Cecil oddly unscathed. ${ }^{34}$ Howard's arrest probably resulted from Herle and Fagot's information, which also influenced Throckmorton's arrest. Tortured in the Tower, over the next few weeks Throckmorton's confession provoked Mendoza's expulsion, a fate Castelnau managed to avoid despite his complicity. However, Herle stepped up his surveillance of Castelnau, hoping that the capture of his fellow conspirators would panic the ambassador into revealing more.

On 23 November, Herle sent another detailed report to Cecil. He described Douglas visiting Castelnau days earlier for another 'long \& ernest consultacyon., 35 Herle must have either seen detailed notes of what they said, or spoken to another present at the covert meeting. In this case Bossy's chain of information from Castelnau's secretary to Fagot, then through Herle to Walsingham and Cecil, seems likely. ${ }^{36}$ Herle revealed that the discussion 'cheeffly conserned the late $1[\mathrm{ett}] \mathrm{re}$ receved from the Scottish Q[ueen]' by the ambassador. ${ }^{37}$ The conspirators feared that Walsingham had intercepted Mary's letter, and revealed 'the secretts' to Elizabeth. Herle again damned Douglas as 'ever a practiser \& irreligyows, \& a reveler in the end of all secretts to serve his own Torne.' Significantly, Douglas held secrets about Mary and the Guises. In a rather clumsy metaphor, Herle described Douglas as playing 'with a verey long ij handed sword, that reches into mani places att ones, beyond this Iland.'

\footnotetext{
${ }^{33}$ Bossy points out that 17 November can probably be ruled out as the date of Throckmorton's arrest, as this was Elizabeth's Accession Day - a national holiday; Bossy, Giordano, p.31.

${ }^{34}$ Robert Parsons, Leicester's Common-Wealth, London, 1641, originally published secretly in 1584; The authorship of this tract is much debated, and the surviving copies are almost all seventeenth century ones when it was used as anti-Puritan polemic; Simon Adams, 'Robert Dudley, Earl of Leicester (1532/31588), $O D N B$, http://www.oxforddnb.com/view/article/8160, accessed 11 May 2010.

${ }^{35}$ Herle to Cecil, 23 November 1583, BL MS Cotton Caligula C VIII, f.204r.

${ }^{36}$ Bossy, Giordano Bruno, pp.31-32.

${ }^{37}$ BL MS Cotton Caligula C VIII, f.204r.
} 
Herle alleged that after Douglas left, Castelnau discussed Throckmorton's capture with his secretary, wondering if he should go to Court and 'by som cowrse of Terrificatyon' 'withdrawe her majestie from procedyng to far in examnyneng these actyons. ${ }^{38}$ Castelnau may have contemplated threatening to withdraw French support from Elizabeth, hoping to push her into backing down. ${ }^{39}$ Herle claimed that Castelnau knew he needed to act quickly, because every moment Cecil and Walsingham had Throckmorton increased the likelihood of uncovering their 'gretter fryndes, nott yett discoverd. ${ }^{40}$ The 'gretter fryndes' were probably the Catholic Earls of Arundel and Northumberland, although Mary and Castelnau are possible candidates. The fact that Castelnau failed to act indicates that he realised exactly how tenuous his position was in England. Castelnau could not risk the chance that demanding Throckmorton's release would provoke Walsingham to examine their relationship more closely.

Herle's letter tried to make the French embassy central to a subversive Catholic plot to overthrow Elizabeth, focusing north of the border on the Scottish Earl of Angus. ${ }^{41}$ Herle accused Angus of choosing companions who were 'ether discontented persons, or Recusants,' and servants who 'were all notoryows papists. ${ }^{42} \mathrm{He}$ assured Cecil that he "thought nott impertynent to have your wisdom acqwaynted therewith, to judge there $\&$ of theire effects, as in vallew they might import. ${ }^{43}$ Clearly Herle, like Cecil, perceived events in England and Scotland as closely linked, given the Marian sympathies amongst the nobility of both nations. As Elizabeth sent Walsingham to monitor the situation in Scotland within weeks, the authorities evidently shared Herle's concerns. $^{44}$

\footnotetext{
38 ibid., f.204r.

${ }^{39}$ Bossy, Giordano Bruno, p.32.

${ }^{40}$ BL MS Cotton Caligula C VIII, f.204r.

41 ibid., f.204r-204v.

42 ibid., f.204v.

43 ibid., f.205r.

${ }^{44}$ Bossy, Under the Molehill, p.75.
} 
By early January 1584, after Walsingham returned from Scotland, Fagot began writing to him once again. ${ }^{45}$ Fagot named some of the same conspirators Herle had in his November communications, notably Douglas and Throckmorton. He confirmed Herle's previous warnings about Douglas, adding that 'he has a pension from the ambassador.' Fagot also emphasised the widespread nature of the conspiracy. He also informed Walsingham of a Catholic prisoner in the Fleet prison, who 'thanked God that M. Throckmorton had not told the truth of what he knew,' for then they would all be doomed. Given Herle's past imprisonment and connections in London, it is likely that Fagot received this information from him.

In February Herle told Walsingham more about Castelnau's visitors. ${ }^{46}$ This series of notes, probably a copy of Herle's own memo as they are not in his hand, is undated and was filed at the end of 1583 in the State Papers. However, its mention of Mendoza having been expelled from England places it after 21 January $1584 .^{47}$ Herle's memo listed people who frequented the embassy: one of Mendoza's former employees named Curtois, Bishop Scory's son Sylvanus, and a French monk named Victor. ${ }^{48}$ Sylvanus, a Catholic convert, formerly served the Earl of Leicester and was a notorious disappointment to his father who had been prominent in the Edwardian church. ${ }^{49}$ Victor, said Herle, was 'sarvinge one Noel,' likely meaning Henry Noel. Noel was an influential courtier, able in 1583 to block prosecution of one of his servants for murdering a carman. ${ }^{50}$ None of this intelligence was probably to lead to more arrests, and Bossy notes the absence of information about the would-be assassin William

\footnotetext{
${ }^{45}$ Henry Fagot to Walsingham, January 1584, TNA SP 12/167, f.155r, original in French translated and reprinted in Bossy, Giordano Bruno, pp.210-212.

${ }^{46}$ Herle to Walsingham, February 1584, TNA SP 12/167/57, ff.154r-154v.

${ }^{47}$ Bossy, Giordano Bruno, p.213.

48 TNA SP 12/167/57, f.154r.

49 Bossy, Giordano Bruno, p.34; Andrew Pettegree, 'John Scorey (d. 1585), 'ODNB, http://www.oxforddnb.com /view/article/24855, accessed 11 May 2010.

50 Steven May, 'Henry Noel (d. 1597),' ODNB, http://www.oxforddnb.com/view/article/20234, accessed 11 May 2010.
} 
Parry's clandestine visits during the same period. ${ }^{51}$ While Parry was no Throckmorton or Howard, there seems no reason why Herle and Fagot should not mention him.

\section{A Discouerie of Treason}

While Herle's surveillance of the French embassy continued, Throckmorton was executed for high treason. At his trial Throckmorton claimed his confession had been falsely extracted, a claim that worried the government enough to publish a pamphlet decrying his change of heart. A Discouerie of the Treasons Practised and Attempted Against the Queenes Maiestie and the Realme by Francus Throckemorton appeared in 1584 and, like Salutem in Christo and The Copie of a Letter did for the Ridolfi plot, provided the government's version of events. ${ }^{52}$ Like these earlier pamphlets, $A$ Discouerie of Treason was published anonymously as 'a letter sent from a Gentleman of Lions Inne to his friend,' although it is often attributed to Cecil. ${ }^{53}$ The pamphlet gives us a clearer understanding of Herle's place in Walsingham's operation. Furthermore, by examining the government's response in light of Herle's writings, we can see what information they included or left out, a factor which can tell us much about the author's intentions.

\section{A Discouerie of Treason was concerned primarily with undermining} Throckmorton's allegations that his confession had been falsely extracted, and was contained 'mere inuentions of himself by police [policy] to auoyde the torture. ${ }^{54}$ To answer these accusations, the pamphlet gave a detailed review of the events around Throckmorton's arrest. It was based upon 'secret intelligence giuen to the Queenes Maiestie,' a phrase which suggests that Herle's reporting of the 'long \& pryvat

\footnotetext{
${ }^{51}$ Bossy, Giordano Bruno, p.34.

${ }^{52}$ See above, p.49.

${ }^{53}$ William Cecil, A Discouerie of the Treasons Practised and Attempted Against the Queenes Maiestie and the Realme, by Francis Throckemorton, London: C. Barker, 1584, STC 24051, no sig., page facing sig.A1r. While the author of this tract was anonymous, it is likely that it was either Cecil, Walsingham, or Thomas Norton. Given Cecil's recent practice in composing The Execution of Iustice, he would seem the likeliest candidate; Alford, Burghley, p.254.

${ }^{54}$ Cecil, A Discouerie of Treason, sig.A1r, B1r.
} 
conferencs' between Throckmorton and Castelnau was instrumental. ${ }^{55}$ The pamphlet emphasised Throckmorton's role as a courier between Mary and 'certaine Catholique Noblemen and gentlemen' whose names were discovered amongst Throckmorton's papers. ${ }^{56}$ Although Herle described Castelnau as the link between Throckmorton, Mary, and other Catholics, Mendoza was depicted as Throckmorton's primary co-conspirator, to whom he 'resorted often,' and who 'did incourage him therein. ${ }^{57}$ Castelnau's complete absence from the tract makes a revealing contrast.

From what Herle told Cecil and Walsingham, we know that the ambassador was deeply implicated in the plot. The fact that A Discouerie of Treason does not mention him implies that Elizabeth and Cecil did not want to alienate France. Mendoza had been a constant irritant since his arrival, while Castelnau had become close with several councillors during the Anjou negotiations, and in the tense international situation England needed the French. After the decision to expel Mendoza, Elizabeth needed friendly relations with Henri to prevent any prospect of a Franco-Spanish Catholic alliance against England. Henri resolved the situation in November 1584 by recalling Castelnau to France.

A Discouerie of Treason hinted at the spectre of international Catholicism that Herle described. Amongst Throckmorton's papers were 'twelve petidegrees of the discent of the Crowne of England...in the defence of the pretended title of the Scottish Queene. ${ }^{58}$ These papers had been 'printed and published by the Bishop of Ross,' and were probably similar to those Herle had reported Bailey carried over from France for the Bishop a decade earlier. ${ }^{59}$ In Cecil's eyes, and like Ridolfi's plan, the Throckmorton plot involved a foreign invasion backed by English Catholics and 'agreed on by the

\footnotetext{
55 ibid., sig.A1v.

56 ibid., sig.A1v-A2r.

57 ibid., sig.B2r, A4r.

58 ibid., sig.A2r.

${ }^{59}$ See above, p.52.
} 
Scottish Queene and her confederats in France,' Rome, and Spain. ${ }^{60}$ The pamphlet named the Duke of Guise as 'the principall leader and executor of that inuasion.' All that prevented the Duke from invading was 'the assistance of a conuenient partie in England to joyne with the forraine forces, and...howe to let the Scottish Queene at libertie without peril of her person.'

\section{Herle's Ambassadorship to East Friesland}

Throughout the early 1580s, Elizabeth refrained from openly confronting Spain in the Netherlands, providing only secret financial assistance to Anjou and the Dutch. ${ }^{61}$ Leicester and Walsingham urged direct involvement, but Anjou used the marriage negotiations to convince the Queen that he could represent her interests, keeping England out of the Netherlands. Anjou's poor leadership contributed to the loss of strategic towns to the Spanish, before he returned to France in June 1583. Anjou died in June 1584, leaving the Huguenot Henry of Navarre embroiled in conflict to pursue his claim as the French heir presumptive, and William of Orange was assassinated in July. This sudden power vacuum in the Netherlands coincided with the formation of the French Catholic League, a paramilitary organisation under the control of the Guisards. The Catholic League looked to Spain for funds and guidance, a fact which confirmed Cecil and Walsingham's suspicions about the pan-European Catholic conspiracy, but more immediately kept the French out of the Netherlands.

In mid-1584 Elizabeth posted Herle to Emden, the main trading port in the northern Netherlands province of East Friesland. As reward for his work in uncovering the Throckmorton plot, Herle received the diplomatic post he had pursued for so many years. This posting meant Herle left his more accustomed milieux in Antwerp for extensive periods, and achieved what could be considered the apex of his career.

\footnotetext{
${ }^{60}$ Cecil, A Discouerie Treasons, sig.A3v.

${ }^{61}$ Doran, Elizabeth I and Foreign Policy, pp.40-41.
} 
Herle's instructions were to ascertain the Counts of East Friesland's views on Spanish rule in the Netherlands. ${ }^{62}$ Walsingham feared that Philip was negotiating for unrestricted access to Emden's waterways, outflanking Dutch defences by opening up the northern provinces of the Low Countries. Herle was to persuade Count Edzar, who controlled the greatest part of the rivers in question, to oppose Philip's attempts to 'increase his greatnes in thes parts to the preiudice of th'Empire and the whole state of Christendom.' Siding with Philip, warned Walsingham, would bring the Count's forcible conversion to Catholicism or deposition. If Edzar refused, Herle was instructed to ask the neighbouring Protestant German princes to pressure the Count. ${ }^{63}$

It reflected the limitations of English diplomacy in the Empire that Walsingham's instructions were vague about how Herle was expected to accomplish his embassy and his powers of negotiation. In late July, Herle raised this issue with Cecil, asking for advice on his negotiations in Emden, explaining that his instructions had not been detailed enough to fully understand what was expected of him. ${ }^{64}$ The fact that Herle addressed this query to Cecil, rather than questioning Walsingham, reflects his appreciation of the delicacy of his relationship with Walsingham. It also indicates that although Herle had worked with Walsingham's agents during the Throckmorton plot, Cecil ensured that Herle received the diplomatic post.

A little over a month after receiving his instructions, on July 22 1584, Herle still lingered in Amsterdam, which he blamed on 'contrarie wyndes' and 'wante of convenient shipping. ${ }^{65}$ Herle's report to Elizabeth described local events in such detail and at such length that he felt compelled to apologise for having 'exceeded muche the proportion and limittes of a $1[\mathrm{ett}] \mathrm{re}$ to a Quene my Soveraigne. ${ }^{66}$ Herle confessed he 'thought not fitt to judge' the wheat from the chaff. Together with his tardiness in

\footnotetext{
${ }^{62}$ Unknown scribe (annotations by Walsingham) to Herle, 8 June 1584, TNA SP 82/1/75, f.72r.

${ }^{63}$ ibid., f.72v.

${ }^{64}$ Herle to Cecil, 29 July 1584, BL MS Lansdowne 43, f.24v.

${ }^{65}$ Herle to Elizabeth I, 22 July 1584, Bodleian MS Rawlinson C 424, ff.1r, 6v.

66 ibid., f.6v.
} 
carrying out the Queen's orders, this was a major blunder, since providing judicious summaries constituted a large part of an ambassador's work. ${ }^{67}$ Overworked senior officials like Cecil and Walsingham waded through mountains of paperwork each day, and needed their subordinates to sift important intelligence from the masses of information they accrued. Herle could never be described as concise, but his reports from this period are particularly prolix. He seems to have been so carried away by the status of the position he had finally gained that he became loquacious with consequence.

The main topic of conversation in Amsterdam was the repercussions of the assassination of William of Orange. Herle reassured Elizabeth that far from crippling efforts against the Spanish, the Prince's murder caused the locals to swear revenge on 'the Tirant of Spaine' and to 'defende their Religion and liberties...even to the last drop of their blood. ${ }^{68}$ Further, said Herle, the Dutch wished to be ruled by neither the French nor the Spanish, and hoped instead that the Queen would assume sovereignty of the Netherlands. Herle tailored his report to Elizabeth's vanity, claiming that the Dutch called her 'their Savior, and the Princesse of greatest perfection in wisedome and sinceritie that ever governed.'

Herle told Elizabeth that Orange's assassin, a Frenchman named Balthasar Gérard, was a Jesuit, information that would help Cecil and Walsingham's attempts to push the Queen towards a more radical anti-Catholic position. ${ }^{69}$ Jesuits were infamous for their resistance theory, that heretical "tyrants" could be murdered in God's service, and Gérard's attack seemed to be evidence of this practice. The government's attack on Jesuit missionaries continued throughout the 1580s. Cecil published his anti-Jesuit propaganda, The Execution of Justice in England, in December 1583, and Herle had

\footnotetext{
${ }^{67}$ See below p.135 for a discussion of Elizabeth's rebuke at Herle's slowness in travelling to Emden.

${ }^{68}$ Bodleian MS Rawlinson C 424, f.1r.

69 ibid.
} 
taken two dozen copies in various languages 'touching the justice in England executed upon those Jesuites and Seminaries, not for religion, but for treason. ${ }^{70}$

Herle knew that identifying the assassin as a Jesuit would support his insinuation that Elizabeth faced similar threats from the Jesuits within England. 'It is a maxime among them,' wrote Herle, 'that they be all Judithes, that kill princes, and ar therfore stirred up and warranted by the Pope to be canonized for the same. ${ }^{71}$ He claimed no shortage of Jesuits willing to do the deed, since 'it is well knowne, that there ar entred above vij score lurking Jesuites into the Realme of late, and they doe secretly repaire more and more. ${ }^{72}$

A week later Herle updated Cecil on his progress. He apologised for the fact that he still had not reached Emden, reiterating his excuses to Elizabeth. ${ }^{73}$ Most of the information in this letter was stale, repeated from his previous report, because, explained Herle, Walsingham had conveyed 'her majesties plesure I sholld dyrect mi packett to her alone.' Herle apologised in advance for sending fewer updates to Cecil than usual, claiming that it was due to the 'obedyence I carye to her majesties wyll \& nott to want of dutye.'

Herle's warning proved accurate, as his next surviving letter from Emden dates from 3 October 1584. It informed Walsingham that Herle had sent a 'packett of $1[\mathrm{ett}] \mathrm{res} . . . \mathrm{conteyneng}$ at large the substance of that which I have negocyated here. ${ }^{74}$ Unfortunately these letters, and the details of Herle's negotiations, are lost. Herle found them frustrating:

The pryncipall cawse which I do handell here is so Towghe, \& these persons so slowe \& dull of capacytye that I have to dele with, as that I canott hitherunto com to any conclusion.

\footnotetext{
70 ibid., f.2v.

71 ibid., f.2r.

${ }^{72}$ ibid., f. $2 \mathrm{v}$.

${ }^{73}$ Herle to Cecil, 29 July 1584, BL MS Lansdowne 43, f.24r.

${ }^{74}$ Herle to Walsingham, 3 October 1584 , TNA SP 83/23/18, f.33r.
} 
Yet Herle felt that the negotiations were approaching success. 'I have so Labord the on \& the other,' wrote Herle, 'that I hope in God to conclude verey shortly their differencs, to her majesties highe comendacyon.' No further letters from Herle about this ambassadorship to East Friesland survive, although more can be gleaned from a Privy Council letter of 1585, after England's stance on the Netherlands had altered dramatically.

\section{Herle's Second Journey to East Friesland}

By 1585 Cecil and Walsingham had convinced Elizabeth that the decline of Dutch fortunes meant England could no longer remain ostensibly neutral in the conflict. John Norris was dispatched to the Netherlands with a small professional force of 2,500 men, with orders to prevent Parma from taking Antwerp. Although Antwerp fell shortly after Norris' arrival, Leicester soon arrived to command a larger expeditionary force. Despite this, the Queen still sought to avoid full-scale war with Spain, and continued to entertain negotiations for peace up until $1588 .{ }^{75}$ If Elizabeth wished to avoid leading the Dutch rebels to victory, she could have hardly picked a more appropriate general than Leicester.

In March 1585, the Privy Council informed Leicester about the situation in Emden. In the months since Herle returned to England, the count had complained to Elizabeth about 'many wronges, spoyles \& injuryes' he felt the Dutch had done to him. ${ }^{76}$ Elizabeth referred the matter to Leicester for mediation, 'as Lieutenat Generall of her forces in thos Countryes.' The Council ordered Leicester to send an envoy to Emden, and Cecil recommended Herle as 'one best acquaintid and of sufficient credite already' with the Count. ${ }^{77}$ Leicester was free to choose another ambassador, 'though it [would] be hard to fynd any meter for this purpose' than Herle. On the other hand,

\footnotetext{
${ }^{75}$ Doran, Elizabeth I and Foreign Policy, pp.52-53.

${ }^{76}$ Privy Council (annotated by Cecil) to Leicester, 20 March 1585, TNA SP 84/7/42, f.86r.

77 ibid., f.86v.
} 
while Elizabeth agreed that Herle was the best choice, the Privy Council reported that she 'hathe noted some slackenes in him in executyon of the charges that have heretofore ben comyted unto him,...tarryeng long in the places to which he hath bene sent. ${ }^{, 78}$ Herle's habit of hiding from his debts overseas when given important responsibilities, had become a problem for the Queen.

Despite Elizabeth's reservations, Leicester gave Herle the task. No letters from Herle dealing with this mission survive, and we must piece together scraps of information from many other sources. Herle had been sent to ensure that English merchants could access Emden unimpeded, and Leicester expected his ambassador's success. He wrote to Cecil between May and June 1585:

For the passage of our merchants to Emden I have delt for yt reasonably I dowbt not \& do look for the retorn of William Herll whome I sent a month synce thether. ${ }^{79}$

Judging Cecil's note about matters to discuss with the Queen, it seems Herle's second visit to Emden did not go smoothly. Contrary to Herle's previous expectations, the Count was now 'wholly devoted to the K[ing] of Spayne,' perhaps because he had 'lately receaved the order of the golden fleese. ${ }^{80}$ The Count's 'intertaynment was could \& contemptible,' conveying 'that he was indifferent, to talk either peace, or war.' Cecil recommended that the 'benefitt of the trade \& traffick of our marchants' be withheld from the Count in future.

Herle's failed mission was an orphan no-one wanted to acknowledge, let alone pay for. Privy Councillors avoided the subject. Cecil made a note to discuss 'the successe [result] of William Herles employement towardes the E[arl] of Emden' with the other Councillors. ${ }^{81}$ However, Leicester later noted that 'her majestie cannot be

\footnotetext{
${ }^{78}$ ibid., f.87r.

${ }^{79}$ Leicester to Cecil, [May-June 1585], TNA SP 84/9/45, f.235v; the documents dealing with Herle's second journey to East Friesland are largely undated. Broad date ranges have been given based upon the Council's recommendation that Herle be sent, in March, and letters written after his return to England, in late June.

${ }^{80}$ ibid., f.254r.

${ }^{81}$ Cecil to Privy Council, [May-June 1585], TNA SP 84/8/94, f.218v.
} 
induced to beare William Herles charges. ${ }^{82}$ As Herle was officially mediating between Emden and the Estates General, argued Leicester, the cost of his travel 'ought to be borne by the States.' Leicester's own expedition was massively under-funded and therefore he was attempting to cut corners by foisting the costs of Herle's travel and upkeep onto the Dutch. No details survive of who paid for Herle's travel, but judging by his rapidly increasing debts Herle was probably left to foot the bill himself.

Herle spent the months between June and August 1585 in London, 'extremely sick, and unable to go to court. $^{83} \mathrm{He}$ saw this as a major impediment to his reimbursement and further employment, and asked Cecil to recommend him to Elizabeth. A delegation from the Low Countries was due to arrive in London. Herle pointed out that since a number of the delegation's members 'have allredie insinuated them selves unto me,' he would be able to gather additional information from them, to aid English negotiators. Unfortunately for Herle, he remained 'greviously sicke,' unable to capitalise on his ties to the Dutch envoys because he could 'scarce walke in my Chaumber. ${ }^{84}$ Even by August 1585, Herle remained 'wasted with melancholie,' and 'not hable to travaile for my self. ${ }^{85} \mathrm{He}$ asked Cecil to remind the Queen of his recent service, and pass on to her his assessment of the situation in East Friesland. Regrettably Cecil was also sick and absent from Court. ${ }^{86}$ Both Herle and Cecil were tired and ill, a fact which probably contributed to the disagreement over the Treasurer's letters discussed in Chapter III which occurred at this point. ${ }^{87}$ Cecil was also possibly still angry with Herle over his failure in Emden.

\footnotetext{
${ }^{82}$ Leicester to Cecil, [May-June 1585], TNA SP 84/8/99, f.93r.

${ }^{83}$ Herle to Cecil, 21 June 1585, BL MS Lansdowne 46, f.14r.

${ }^{84}$ Herle to Cecil, 8 July 1585, BL MS Lansdowne 46, f.22r.

${ }^{85}$ BL MS Lansdowne 46, f.36r.

${ }^{86}$ TNA SP $12 / 181 / 56$, f.190r.

${ }^{87}$ See above, p.88ff.
} 


\section{Herle's Third Journey to East Friesland}

By December 1585 Herle's disagreement with Cecil was sufficiently forgotten that Herle felt able to send the Lord Treasurer a substantial memorandum on the state of the Low Countries, intended for the Queen. ${ }^{88}$ Herle recommended comprehensive antiSpanish action in the Low Countries. Any measure taken against Philip was reasonable, argued Herle, because he had conspired to destroy 'your person and kingdom, to satisfie his unmeasurable ambition, that aspires to the vth monarchie of the worlde, under his unlawfull Catholick title. ${ }^{89}$ Herle's reference to the fifth monarchy drew on apocalyptic ideas of a final universal empire described in the book of Daniel, which heralded the end of days. ${ }^{90}$ Indeed, this letter is far more religious in tone than the majority of Herle's reports. He describes Philip as 'an heretick,...the usurper of Kingdomes, and the subverter of Goddes trew religion,' a foe Elizabeth was duty-bound to oppose. ${ }^{91}$ Herle asked the Queen to burn 'these my papers and observacons, for I have none to beholde nor trust to, but yourself. ${ }^{, 92}$ She obviously ignored his request; somewhat ironically, given the number of Herle's other letters which have been lost.

Herle suggested renewed negotiations with the Count of Emden to open East Friesland's waterways to English ships, and close them to the Spanish. ${ }^{93}$ This evidently appealed to Elizabeth, as Herle made another journey to Emden in 1586. The only evidence about this journey is Leicester's passing mention in August. He informed Cecil that he was 'faine to referre all things to the report of Master Herle, especially touching the matter of Embden,...wherin he can thorowly advertise you what is doon,

\footnotetext{
${ }^{88}$ Herle to Elizabeth I, 20 December 1585, TNA SP 84/5/133, ff.244r-245v; the document has been annotated in Cecil's hand, indicating that the Lord Treasurer had possession of it.

${ }^{89}$ ibid., f.244v.

90 'And in the dayes of these kinges, shall the God of heauen set vp a kingdome, which shall neuer be destroyed, and this kingdome shall not be geuen ouer to another people: but it shall breake and destroy al these kingdomes, and it shal stand for euer.' Bishop's Bible, 1568, Book of Daniel, 2.44.

${ }^{91}$ TNA SP $84 / 5 / 133$, f.244v.

92 ibid., f.245v.

${ }^{93}$ ibid., f.245r.
} 
being imployed there for her majesty. ${ }^{94}$ A few days later he assured Cecil that despite his earlier lapses, Herle had 'taken great travell in this voyage to Emden,' and 'byn carefull to do me all servyce for hir majestie that he could for his havior. ${ }^{95}$ Herle must have gone to East Friesland significantly before August. By 22 August 1586 he had returned to his lodgings at Temple Bar in London. In October he wrote 'I have spent vij moneths, beyng a poore man' which helps date his trip to March 1586, and shows that he still had not been reimbursed for his expenses. ${ }^{96}$

Immediately upon his return in August, Herle reported to Cecil. Though he had been careful to avoid delays this time, he had been 'most dangerowsly tossed att seas with contrary wyndes, with excedyng stormes, \& with incredible lightnyng \& thonders. ${ }^{97}$ Exhausted by his travails, Herle promised to make his report in person the next day. If he submitted a detailed written report of his actions in East Friesland it has disappeared. His next letter to Cecil, however, claims that Herle 'well served' the Queen and her merchants 'preserved from undoyng att Embden." 98 Herle's mention of merchants suggests he had been negotiating over England's trade interests in the northern Netherlands. With the southern Netherlands increasingly under Spanish dominance, Elizabeth needed to secure the northern route to the German states and their lucrative markets.

Herle attempted to leverage some recompense from the success of his latest mission. Herle described the outcome of his mission with cloying false humility:

Whatt honor it dyd purchasse to [her] majestie in those partes, whatt assurance to our Traffyck \& merchants \& how grett obligacion in Erlle Edzard, for the favor Receved, by her majesties procurement, is fitter for your L[ordship] to judge, than for me [to] expresse. ${ }^{99}$

\footnotetext{
${ }^{94}$ Leicester to Cecil, 8 August 1586, TNA SP 84/9/74, f.164r.

95 Leicester to Cecil, 10 August 1586, SP 84/9/81, f.198v; although Herle is not mentioned by name, it is clear from the context that Dudley meant him when he said 'this bearer.' Further evidence for this is provided by Cecil's annotation 'by William Herle' on the address leaf.

${ }^{96}$ BL MS Lansdowne 51, f.41v.

${ }^{97}$ Herle to Cecil, 22 August 1586, TNA SP 84/9/102, f.247r.

${ }^{98}$ BL MS Lansdowne 51, f.41r.

99 ibid., ff.41r-41v.
} 
Nevertheless, Herle asked 'that mi expences \& dyett be answerd.' ${ }^{100}$ Leicester had assured him 'that 'servants ar nott to bere the charge of their Soveraignes service,' but his last journey to East Friesland cost him $£ 300$ 'of myne own purse.' Herle had not, he claimed, 'receved of her majestie' $£ 800$ 'to this daye in recompense of all mi poore services.' Herle begged Cecil to 'hellp mi cawse' when Walsingham returned to Court.

Herle's inability to gain reimbursement for his diplomatic services was not an uncommon problem amongst Elizabethan ambassadors. Valentine Dale, ambassador in Paris between 1573 and 1576, accumulated a large debt which he never paid off. ${ }^{101}$ Robert Beale was given a diet of $£ 2$ per day as ambassador to the German princes in 1577-1578, but claimed that his journey cost him far more than this. ${ }^{102}$ Even Sir Nicholas Throckmorton, given a magnificent allowance of plate with which to impress the French during his 1559 embassy in Paris, was forced to take out a loan of $£ 1,000$ to cover his expenses. ${ }^{103}$ This frugality on Elizabeth's part could cause serious problems, probably contributing to Sir Edward Stafford's acceptance of 3,000 crowns from the Duke of Guise to allow him to read the reports Stafford sent to Elizabeth. ${ }^{104}$ The only way to recoup such losses was through further service, with the hope that this would eventually lead to a lucrative position or pension. Walsingham himself had experienced significant financial difficulties when he was appointed ambassador to Paris in 1570 with a diet of $£ 3 / 6 / 8$ per day, but easily paid off his debts after being appointed Secretary and Privy Councillor on 20 December $1573 .{ }^{105}$

\footnotetext{
${ }^{100}$ ibid., f.41v.

${ }^{101}$ Michael Hicks, 'Valentine Dale (1520-1589),' ODNB, http://www.oxforddnb.com/view/article/7021, accessed 11 May 2010.

102 Gary Bell, 'Robert Beale (1541-1601),' ODNB, http://www.oxforddnb.com/view/article/1804, accessed 11 May 2010.

${ }^{103}$ Stanford Lehmberg, 'Sir Nicholas Throckmorton (1515/15-1571), ODNB, http://www.oxforddnb.com/ view/article/27394, accessed 11 May 2010.

104 James McDermott, 'Sir Edward Stafford (1552-1605),' ODNB, http://www.oxforddnb.com/view/ article/26203, accessed 11 May 2010.

${ }^{105}$ Simon Adams, Alan Bryson, and Mitchell Leimon, 'Sir Francis Walsingham (c.1532-1590),' ODNB, http:// www.oxforddnb.com/view/article/28624, accessed 11 May 2010.
} 
In January of 1587, still apparently deeply in debt, Herle attempted to repeat his previous success in the Netherlands by asking Cecil to post him there. Although the letter is badly damaged, Herle clearly hoped the Treasurer would be 'disposed to employe me in Holland' so that he could work on Cecil's behalf and strive 'withall mi skyll \& diligence to obey yow. ${ }^{106}$ When this last attempt to recover his finances through service failed, he asked for Elizabeth's permission to leave England. 'I have nether fee lefte to serve her, nether credite nor hope to mayntayne mi sellf longer, nor ever had land or office, to tye me' to England, claimed Herle. Now he sought leave 'to gett mi lyveng abrode. ${ }^{107}$ Herle also hoped for 'her graciows Testymoniall \& favor, for mi loyall behavior \& duty contynewed, to her majestie \& the State, duryng mi service.' With these two last gifts, Herle declared, 'I shall holld my sellf fully satisfyed \& rewarded.' Despite his complaints about lack of rewards, Herle promised to maintain his ties with Cecil, stating that 'yf I lyve \& prevayll abrode your L[ordship] shall fynde, that I will nott be undutifull for your honorable goodnes towards me wherof I have very largely tasted. ${ }^{108}$

\section{Herle's Death}

While Herle's last letter contains many of the same complaints about his debts and Elizabeth's failure to reward his services, it also contains evidence of his impending death. In the month between 12 April 1588, when Herle again asked Cecil for permission to travel to Germany, and 3 May 1588, Herle's health went rapidly downhill. ${ }^{109}$ 'I have bin of late,' he complained, 'at dethes dore, escaping the going in very narowly, butt God in the myddest of mi greves \& angwisshes, doth still releve \&

\footnotetext{
${ }^{106}$ BL MS Cotton Galba C XI, f.76r.

${ }^{107}$ BL MS Lansdowne 55, f.217r.

108 ibid., ff. $217 \mathrm{r}-217 \mathrm{v}$.

${ }^{109}$ Herle to Cecil, 12 April 1588, BL MS Lansdowne 58, ff.67r-67v; Herle to Cecil, 3 May 1588, TNA SP $12 / 210 / 4$, ff. $7 r-7 v$.
} 
delyver me. ${ }^{110}$ Herle's escape from death, cannot have been quite as narrow as he claimed, because he still hoped to travel in Europe if given 'leve for mi departure.' Yet despite this, the letter reads very much as a final appeal. Herle, having written little about his religious convictions previously, used the language of a man who felt his death was imminent. 'There is a God that beholldeth \& censureth all things, otherwise unkyndenes \& greeff, had long synce kylled me,' wrote Herle. His mention of 'unkyndenes' was likely in response to Cecil's indifference at Herle's plight. 'Yf He that forgave mi synes, most paye mi detts, I humbly refferre it to his devyne goodnes $\&$ dispensation, that sees the cleerenes \& grownd of mi conscyens on that behallf, byddyng the worlld A diew.'

This letter of 3 May 1588 was Herle's last, and he died shortly afterwards. Although his exact date of death remains unknown, we know he died at some point between writing this letter and Leicester's death on 4 September $1588{ }^{111}$ A packet of Herle's letters in the National Archives bears the inscription:

L[ett]res to W[illia]m Herle from my L[ord] Burghley L[ord] Tresoror of England, found amongst his wrytyngs and brought to the Erle of Lecester at the deth of Herle. ${ }^{112}$

A date closer to May than September would seem likely, given the lack of further letters from the normally prolific Herle, and Leicester's preoccupation with preparations against the Armada that summer. Robyn Adams notes that the administration of Herle's goods was granted on 8 February $1589 .{ }^{113}$ Considering Herle's dire financial straits at the time of his death, he would have had little to pass on to any surviving relatives.

\footnotetext{
110 TNA SP 12/210/4, f.7r.

111 Adams, 'Robert Dudley, Earl of Leicester (1532/3-1588).'

${ }^{112}$ Cecil to Herle, 18 August 1585, TNA SP 12/181/43.

113 Prerogative Court of Canterbury, London, 'William Herle St Clement without the bar of the New Temple, London, 1589, f.90,' Edward Alexander Fry (ed.), Index of Wills Proved in the Prerogative Court of Canterbury, Vol.3 (1558-1604), London: British Records Society, 1907, p.79. Cited in Adams

"'Both Diligent and Secret,' p.11.
} 
This chapter has charted the last years of Herle's life, beginning with the Throckmorton plot and ending with his death. It has argued that Herle's role in uncovering the Throckmorton plot was greater than previous historians have believed, and that his description of the plot's main elements was probably the first accurate information that Cecil received about its scope. It further argued that Herle was responsible for the early emphasis placed on Henry Howard in reports of conspirators, a focus Herle encouraged due to his belief that undermining Howard would ensure Cecil's continued dominance, as Norfolk's execution had a decade earlier. The comparison of the raw intelligence contained within Herle's reports to the government account in A Discouerie of Treason shows how the information Herle provided was edited for political purposes.

The diplomatic high point of Herle's career during his embassies to East Friesland merely added to his mounting debts. The high cost of embassies was a problem common to Elizabethan administrators, and could only be solved through gaining sufficient rewards to counter any debts run up during Crown service. While some ambassadors were rewarded amply, Herle was not. Although two of his three embassies to East Friesland seem to have been successful, his one failure seems to have been enough to convince Cecil and Elizabeth that he did not have the necessary abilities to become a career diplomat. Herle's rapidly deteriorating health, his quarrel with Cecil detailed in Chapter III, and his mistaken report of Orange's death described in Chapter IV, probably all contributed to Herle's superiors' abandonment of him in his final months. 


\section{Conclusion}

This thesis has analysed William Herle's letters in their historical context. In doing so, it has provided new insights into both his life and the wider Elizabethan world. While previous historians have largely ignored Herle, we now have a detailed study of Herle's life in its historical context to complement the extensive literary analysis of his letters that Robyn Adams has published over the last five years. This study has shown that a focus on the more unsavoury aspects of Herle's life led previous historians to dismiss his significance prematurely. Conyers Read's judgement of Herle has enjoyed unwarranted longevity through others' willingness to focus on Herle's involvement in the Ridolfi plot to the exclusion of other aspects of his life. Through reassessing Herle's life as a whole, we have seen that his role as a spy and stool pigeon was only one small facet of his remarkably active and varied career.

The first chapter introduced us to two of the overarching themes of this thesis: the dual nature of Herle's career, and his life-long association with his patron, William Cecil. Herle was unremarkable amongst the Tudor gentry in his early life, leaving no records behind and entering into the lucrative trade with Antwerp under the tutelage of Sir William Garrard. When Elizabeth took the throne in 1559 Herle's life changed completely, as he was brought into Crown service while Cecil became Secretary of State. This proved the first of many times in which Herle reinvented himself to advance his career. While Herle enjoyed five years of success in his new role negotiating loans for the government in Antwerp, his career derailed in 1565 by increasing debts and accusations of piracy.

Chapter II detailed Herle's role in the Ridolfi plot, and his reports of other conspiracies in its aftermath. Having ended any chance of a respectable career in finance with his foray into piracy, Herle expanded the intelligence gathering role he had 
dabbled in over the preceding decade into his primary occupation. He played a crucial role in uncovering the Ridolfi plot and entrapping its instigators, a success which he failed to replicate through his further efforts as a spy.

The third chapter emphasised the centrality of Herle's patronage ties to his life. A solid patron-client relationship was vital to his social standing, career advancement, and even his survival. While he cultivated a number of powerful patrons, his ties to Cecil were the most important consideration in Herle's life. Cecil provided protection and rewards for useful service. It was only through the Secretary's frequent intervention that Herle's creditors were kept at bay, with stallments preventing those less well connected than Herle from collecting on his numerous debts. While Herle received a number of rewards for his service they tended to be lost soon after. The lease in reversion he received for his work in the Ridolfi plot was discharged early to pay off his creditors and his office of Rhaglaw in Cardiganshire was sold back to the locals. This thesis has argued that even the monopoly Herle received on oil production was given up to settle his debt with the Waads. The only office he seems to have held for an extended period of time was as the gentleman porter in the Tower.

We have seen that the primary reason for Herle's interminable indebtedness was the inefficiencies of the English civil service. Herle's positions took him overseas for extended periods of time, particularly to the Netherlands as detailed in Chapter IV, where he was forced to pay his own way through taking out loans in the absence of government funding. Herle experienced similar problems recouping the losses he incurred during his embassies to East Friesland, and his difficulties were shared by many other Elizabethan ambassadors, indicating the problem was with the system rather than Herle. While he always attempted to recoup his losses upon returning to England, Elizabeth and Cecil preferred to force his creditors to wait for repayment, rather than paying back Herle's loans for him. While this gave Herle temporary relief, it proved a 
long term disaster for his finances, as his debt compounded with every new posting. This was the dark side of the patronage system, with those in power abusing Herle's dependence on their benevolence and pushing him into a cycle of poverty he could never hope to escape from.

While Herle remained useful to his patrons, they acted on his behalf. This was particularly noticeable in his early career, with Cecil organising Herle's release from prison and providing a letter of recommendation for Herle to press a marriage suit. The fact that these actions on Herle's behalf decreased over the course of his career implies that it was future, rather than past, service which motivated his patrons' generosity. As a young man who was largely unknown and with a lifetime of potential service ahead of him Herle was useful to Cecil, and he exerted this leverage to substantial reward. As his profile raised and his ties to Cecil became widely known, however, Herle's utility as a spy decreased. He expended much of his credit with Cecil and Elizabeth in an attempt to find more secure offices, but never managed to find one that would allow him to both maintain his patronage ties and make his fortune.

Herle's conflict with Cecil in 1585 over his alleged dispersal of the Lord Treasurer's letters proved a watershed moment in his life. While Herle maintained a solid business relationship with Cecil after their disagreement, the amicable tone which characterised their early letters was markedly absent from later communications. Herle's move from a narrow but solid patronage base with Cecil to a wider but weaker one that utilised Cecil, Leicester, and Walsingham's influence proved problematic for him in the long term. His inability to leverage their professed support into concrete benefits was exemplified by his failure to garner the position of clerk to the Privy Council. Despite support from both Cecil and Leicester for Herle's bid, Hatton's candidate received the post ahead of him. 
While Herle failed to turn the patronage system fully to his benefit, this was clearly not the case with all the Elizabethan gentry. Thomas Waad was noted in Chapter III as an example of someone of similar social standing to Herle who was able to gain far more from his patronage ties to Cecil and Walsingham than Herle ever did. As we saw, this success was less about Waad's comparative merit than it was his age and the timing of his rewards. Herle was middle aged before he received his first real ambassadorship, in the form of his three journeys to East Friesland that were detailed in Chapter V, whereas Waad acted as secretary to various ambassadors from his early twenties. Herle's liminal status, moving between intelligencer, diplomat, and criminal throughout his life, meant that he was unable to concentrate on a single area long enough to climb up the social ladder.

Despite the extremes that Herle experienced in his career, he remained a gentleman all his life. His massive debts and frequent imprisonment had no lasting effect on his social standing, nor did the bestowal of the office of Rhaglaw or his appointment to ambassadorships. Herle's experiences are indicative of a wider lack of social mobility in Elizabethan society. While truly exceptional individuals such as Cecil and Walsingham transcended the stratification of Elizabethan society, for the majority any rise or fall was a generational process. Herle was born a member of the gentry, and died as such.

The litigious nature of Elizabethan society is apparent throughout Herle's letters. While no Chancery Court records of Herle's cases survive, we have seen his involvement in a wide variety of legal battles reflected in his writings. From his deposition for piracy, to his protracted legal battles with the Waad brothers and the Cardiganshire gentry, to his numerous creditors suing him for unpaid debts, Herle was clearly an active member of one of the most litigious societies in world history. If other Elizabethans of his social standing were as prolifically legalistic as Herle, while leaving 
similarly few official records of such, then this aspect of Tudor society has been substantially underestimated by the current historiography.

Perhaps most interestingly, Herle's letters have provided us with an unprecedented insight into the mindset of some of the most powerful men in Elizabethan England. Herle's experiences show how significant Cecil's fear of an international Catholic conspiracy was in the formation of English foreign and domestic policy. While Walsingham and Leicester's opinions are not as clearly implied in Herle's letters as Cecil's are, the fact that Herle copied many of his detailed reports on the conspiracy to these councillors indicates that the core of the Elizabethan Privy Council maintained a pessimistic, perhaps even alarmist, view of the international situation. The dichotomous view of the world as divided into good and evil, that historians such as Collinson, Lake, and Smith have argued was central to early modern thinking, has been confirmed in Herle's letters, with the addendum that these terms were synonymous with Protestant and Catholic, Anglo-Dutch and Franco-Spanish.

The centrality of the Anjou Match to Elizabethan politics has been corroborated by Herle's letters. It not only dictated English attitudes towards the French and Spanish, but informed Herle's prioritisation of information he passed to Cecil. The marriage negotiations also demonstrated Cecil's political acumen as he manipulated both the Dutch and his Queen. While the Lord Treasurer publicly encouraged Elizabeth to entertain Anjou's advances despite opposition from other councillors, revitalising his waning influence over the Queen, he secretly utilised Herle as a back channel to advise the Dutch on how best to ensure Elizabeth's intervention in the Netherlands. This secondary level of negotiation is a fascinating area that higher level discussions of politics have been unable to explore.

The importance of men such as Herle in enabling the Elizabethan governmental system to function has been demonstrated throughout this thesis. We have seen how 
Herle's reports directly influenced government policy over and over again. The underdeveloped nature of international communications meant that policy makers at the highest level were reliant on Herle's ability to observe events in Europe and report back in a timely and accurate manner. The problems inherent in this system were shown through Herle's premature reporting of Orange's death, with the lambasting he received from Elizabeth and Cecil demonstrating how disastrous inaccurate information could be. Similarly, Henry Howard's arrest as one of the Throckmorton plot conspirators can probably be laid at Herle's feet. The fact that Walsingham was willing to order the arrest of one of England's leading nobles largely due to evidence provided by Herle indicates the degree to which Privy Councillors relied on those who provided them with information. Contrary to David Lewis Jones' snipe that Herle's 'powerful friends...considered him useful but not entirely trustworthy,' Herle played an integral role in the Tudor governmental system. ${ }^{1}$

\footnotetext{
${ }^{1}$ Lewis Jones, 'William Herle (d. 1588/9),'
} 


\section{Bibliography}

\section{Primary Sources}

\section{Calendars}

Boyd, W.K. (ed.), Calendar of State Papers, Scotland and Mary, Queen of Scots, Edinburgh, 1910, Vols. 3, 4.

Butler, A.J. (ed.), Calendar of State Papers Foreign, Elizabeth, London, 1907, Vols. 11, $15,16,18,19,20,21$.

Dasent, John (ed.), Acts of the Privy Council of England, London, 1890, Vols.7, 14.

Inderwick, F. A. (ed.), Calendar of Inner Temple Records: Volume I, 1505-1603, London, 1896.

\section{Manuscript Sources}

Documents from the following collections were accessed through two online initiatives:

The National Archives' State Papers Online [http://gale.cengage.co.uk/statepapers-online-15091714.aspx]; and London University's Centre for Editing Lives and Letters [www.livesandletters.ac.uk]

Bodleian Library, Oxford, Rawlinson C 424.

British Library, Additional 34, 48, 15891, 48023, 5935.

British Library, Burney 390.

British Library, Cotton Caligula C III, C VIII, E VII.

British Library, Cotton Galba C II, C IV, C VII, C VIII, C XI, D II, D IX.

British Library, Cotton Nero.

British Library, Cotton Titus B V, B VII, F III.

British Library, Cotton Vespasian C VII, C XIII.

British Library, Egerton 2790. 
British Library, Harleian 286.

British Library, Lansdowne 7, 9, 12, 13, 15, 16, 18, 19, 21, 22, 23, 24, 25, 27, 28, 29, $31,34,36,37,39,43,46,51,54,55,58,59,155$.

Hatfield House, Hertfordshire, Cecil Papers 8, 9, 12, 160, 162.

Instituto de Valencia de Don Juan, Madrid, Manuscript Collection.

Longleat House, Wiltshire, Bath Dudley Papers II.

The National Archive, London, High Court of the Admiralty I.

The National Archive, London, Privy Council 2.

The National Archive, London, State Papers 12, 15, 46, 52, 53, 63, 70, 77, 81, 82, 83, $84,101,103,105$.

\section{Printed Sources}

Allen, William, A Sincere and Modest Defence of English Catholiques that Suffer for their Faith both at Home and Abroad, Rouen: Fr. Parson's Press, 1584, STC 373.

Cecil, William, The Copie of a Letter Written by One in London to his Frend Concernyng the Credit of the Late Published Detection of the Doynges of the Ladie Marie of Scotland, London: John Day, 1572, STC 17565.

- The Execution of Iustice in England for Maintenaunce of Publique and Christian Peace Against Certeine Stirrirs of Sedition, and Adherents to the Traytors and Enemies of the Realme, London: Christopher Barker, 1583, STC 4902.

Dee, John, General and Rare Memorials Pertayning to the Perfect Arte of Nauigation, London: John Day, 1577, STC 6459.

D'Ewes, Simonds, A Compleat Journal of the Notes Speeches and Debates both of the House of Lords and House of Commons Throughout the Whole Reign of Queen Elizabeth of Glorious Memory, London: Paul Bowes, 1693. 
Howard, Henry, A Defensatiue against the Poyson of Supposed Prophesies, London: John Charlewood, 1583, STC 13859.

Jáuregui y Aguilar, Juan de, A Briefe Discourse of the Assault, Committed Vpon the Person of the Most Noble Prince, the Lord William Prince of Orange, Earle of Nassau, Marques de la Vere \&c, London: Thomas Dawson, 1582, STC 25714.

Leslie, John, A Treatise of Treasons Against Queen Elizabeth, and the Croune of England Diuided into Two Partes, Louvain: J. Fowler, 1572, STC 7601. A Treatise Concerning the Defence of the Honour of the Right High, Mightie and Noble Princesse, Marie Queene of Scotland, and Douager of France with a Declaration, as Wel of her Right, Title, and Interest, to the Succession of the Croune of England, Louvain: J. Fowler, 1571, STC 15506.

Norton, Thomas, A Discourse Touching the Pretended Match Betwene the Duke of Norfolke and the Queene of Scottes, London: John Day, 1569, STC 13869.

Parsons, Robert, Leicester's Common-Wealth, London, 1641, originally published secretly in 1584, STC L969.

Q.Z. (likely William Cecil), A Discouerie of the Treasons Practised and Attempted Against the Queenes Maiestie and the Realme, by Francis Throckemorton who was for the Same Arraigned and Condemned in Guyld Hall, in the Citie of London, the One and Twentie Day of May Last Past, London: C. Barker, 1584, STC 240505.

R.G., Salutem in Christo, London: John Day, 1571, STC 11504.

Stubbes, John, The Discourie of a Gaping Gulf VVereinto England is Like to be Swallovved by Another French Marriage, if the Lord Forbid Not the Banes, by Letting Her Maiestie See the Sin and Punishment Thereof, London: H. Singleton, 1579, STC 23400. 


\section{Secondary Sources}

\section{Unpublished Theses}

Adams, Robyn, “"Both Diligent and Secret”: The Intelligence Letters of William Herle,' $\mathrm{PhD}$ Dissertation, University of London, 2004.

Morrison, George, 'The Land, Family, and Domestic Following of William Cecil, Lord Burghley, c.1550-1598,' PhD Dissertation, Oxford University, 1990.

\section{Journal Articles}

Adams, Robyn, 'A Spy on the Payroll?: William Herle and the Mid Elizabethan Polity,' Historical Research, Vol.83, Issue 220, 2010, pp.1-15.

_ 'Signs of Intelligence: William Herle's Report of the Dutch Situation, 1573,' Lives and Letters, Vol.1, No.1, Spring 2009, pp.1-18.

_ , 'The Service I am Here for: William Herle in the Marshalsea Prison, 1571,' The Huntington Library Quarterly, Vol.72, No.2, 2009, pp.217-238.

Brennan, Michael, 'Review of Surveillance, Militarism, and Drama in Elizabethan England,' The English Historical Review, Vol.113, No.452, June 1998, pp.726727.

Burt, Richard, 'Review of Surveillance, Militarism, and Drama in Elizabethan England,' Shakespeare Quarterly, Vol.49, No.4, Winter 1998, pp.464-466.

Collinson, Patrick, 'Servants and Citizens: Robert Beale and Other Elizabethans,' Historical Research, Vol.79, Issue 206, 2006, pp.488-511.

— , 'The Politics of Religion and the Religion of Politics in Elizabethan England,' Historical Research, Vol.82, no.215, pp.74-92.

Costello, Peter, 'Review of Giordano Bruno and the Embassy Affair,' Studies: An Irish Quarterly Review, vol.81, no.321 (Spring 1992), pp.124-126.

Croft, Pauline, 'Review of Plots and Plotters in the Reign of Elizabeth I,' The Catholic Historical Review, Vol.90, No.2, April 2004, p.321 
Elton, Geoffrey, 'Presidential Address: Tudor Government, The Points of Contact I, Parliament,' Transactions of the Royal Historical Society, Fifth Series, Vol.24, 1974, pp.183-200.

— Court,' Transactions of the Royal Historical Society, Fifth Series, Vol.26, 1976, pp.211-228.

Haigh, Christopher, 'Success and Failure in the English Reformation,' Past and Present, No.173, Nov. 2001, pp.28-49.

Hammer, Paul, 'Review of Her Majesty's Spymaster,' The Journal of Military History, Vol.71, No.1, January 2007, pp.216-217.

Heisch, Allison, 'Arguments for an Execution: Queen Elizabeth's "White Paper" and Lord Burghley's "Blue Pencil,", Albion: a Quarterly Journal Concerned with British Studies, Vol.24, No.4, Winter 1992, pp.591-604.

Lewis Jones, David, 'William Herle and the Office of Rhaglaw in Elizabethan Cardiganshire,' National Library of Wales Journal, vol.17, 1971-72, pp.161179.

Lake, Peter, 'A Tale of Two Episcopal Surveys: The Strange Fates of Edmund Grindal and Cuthbert Mayne Revisited,' Transactions of the Royal Historical Society, Sixth Series, Vol.18, 2008, pp.129-163.

— , "Spain, Her Enemies and the Revolt of the Netherlands 1559-1648," Past and Present, No.49, 1970, 72-95.

Loades, David, 'Review of Invisible Power: The Elizabethan Secret Services, 15701603,' The English Historical Review, Vol.110, No.437, June 1995, p.731.

McCoog, Thomas M., 'The English Jesuit Mission and the French Match, 1579-1581,' The Catholic Historical Review, Vol.87, No.2, Apr. 2001, pp.185-213. 
Parker, Geoffrey 'The Place of England in the Messianic Vision of Philip II of Spain: The Prothero Lecture,' Transactions of the Royal Historical Society, Sixth Series, Vol.12, 2002, pp.167-221.

Parry, Glyn, 'John Dee and the Elizabethan British Empire in its European Context,' The Historical Journal, Vol.49, No.3, Sep. 2006, pp.643-675.

Pollit, Ronald, 'Review of Invisible Power: The Elizabethan Secret Services, 15701603,'Albion: A Quarterly Journal Concerned with British Studies, Vol.25, No.3, Autumn 1993, pp.487-488.

\section{Books \& Edited Collections}

Adams, Simon, Leicester and the Court: Essays on Elizabethan Politics, Manchester, 2002.

Alford, Stephen, Burghley: William Cecil at the Court of Elizabeth I, New Haven (Conn.), 2008.

Baldwin Smith, Lacey, Treason in Tudor England: Politics and Paranoia, Princeton (N.J.), 1986.

Barnett, Richard, Place, Profit, and Power: A Study of the Servants of William Cecil, Elizabethan Statesman, Chapel Hill (N.C.), 1969.

Berckman, Evelyn, Victims of Piracy: The Admiralty Court, 1575-1678, London, 1979.

Black, J.B., The Reign of Elizabeth, 1558-1603, Oxford, 1936.

Bossy, John, Giordano Bruno and the Embassy Affair, New Haven (Conn.), 1991.

—, Under the Molehill: An Elizabethan Spy Story, New Haven (Conn.), 2001.

Breight, Curtis C., Surveillance, Militarism, and Drama in the Elizabethan Era, New York (N.Y.), 1996.

Budiansky, Stephen, Her Majesty's Spymaster: Elizabeth I, Sir Francis Walsingham, and the Birth of Modern Espionage, London, 2005.

Collinson, Patrick, Elizabeth I, Oxford University Press, 2007. 
— Elizabethans, London, 2003.

—, 'Pulling the Strings: Religion and Politics in the Progress of 1578,' in Jayne Archer, Elizabeth Goldring, and Sarah Knight (eds.), The Progresses, Pageants, and Entertainments of Queen Elizabeth I, Oxford, 2007, pp.122-142.

Croft, Pauline (ed.), Patronage, Culture, and Power: The Early Cecils, 1558-1612, New Haven (Conn.), 2002.

Doran, Susan, Elizabeth I and Foreign Policy, 1558-1603, London, 2000.

— England and Europe, 1485-1603, London, 1986.

— England and Europe in the Sixteenth Century, New York (N.Y.), 1999.

—, Monarchy and Matrimony: The Courtships of Elizabeth I, London, 1996.

Edwards, Francis, The Dangerous Queen, London, 1964.

—, The Marvellous Chance: Thomas Howard, Fourth Duke of Norfolk, and the Ridolphi Plot, 1570-1572, London, 1968.

—, Plots and Plotters in the Reign of Elizabeth I, Dublin, 2002.

Elton, Geoffrey, 'Piscatorial Politics in the Early Parliaments of Elizabeth I,' Studies in Tudor and Stuart Politics and Government: Volume IV, Cambridge, 1992, pp.109-130.

Gosse, Philip, The History of Piracy, London, 1934.

Guy, John, Tudor England, Oxford, 1988.

Haigh, Christopher, Elizabeth I, $2^{\text {nd }}$ ed., Harlow, 2001.

- English Reformations: Religion, Politics, and Society under the Tudors, Oxford, 1993.

Haynes, Alan, The Elizabethan Secret Services, $2^{\text {nd }}$ ed., Stroud, 2000.

Jardine, Lisa, The Awful End of Prince William the Silent: The First Assassination of a Head of State with a Handgun, London, 2005. 
Kettering, Sharon, Patrons, Brokers, and Clients in Seventeenth-Century France, New York (NY), 1986.

Knecht, R.J., The French Wars of Religion: 1559-1598, $2^{\text {nd }}$ ed., Harlow, 1996.

Loades, David, The Cecils: Privilege and Power Behind the Throne, Kew, 2007.

—, Politics and Nation: England, 1450-1660, 5th ed., Oxford, 1999.

— Power in Tudor England, New York (N.Y.), 1997.

—

MacCaffrey, Wallace T, Queen Elizabeth and the Making of Policy, 1572-1588, Princeton (N.J.), 1981.

—, The Shaping of the Elizabethan Regime, Princeton (N.J.), 1968.

Nicholl, Charles, The Reckoning: The Murder of Christopher Marlowe, London, 1992.

Parker, Geoffrey, The Dutch Revolt, Revised ed., London, 1985.

—, The Grand Strategy of Philip II, New Haven (Conn.), 1998.

Plowden, Alison, The Elizabethan Secret Service, New York (N.Y.), 1991.

—, Two Queens in One Isle: The Deadly Relationship of Elizabeth I and Mary Queen of Scots, Brighton, 1984.

Read, Conyers, Lord Burghley and Queen Elizabeth, New York (N.Y.), 1960.

—, Mr Secretary Walsingham and the Policy of Queen Elizabeth: Vols. I-III, Oxford, 1925.

Sutherland, N.M., The Massacre of St Bartholomew and the European Conflict, 15591572, London, 1973.

Warren, John, Elizabeth I: Religion and Foreign Affairs, 2nd ed., London, 2002.

Wernham, R.B., Before the Armada: The Growth of English Foreign Policy, 14851588, London, 1966.

Williams, Neville, Thomas Howard, Fourth Duke of Norfolk, London, 1964.

Williams, Penry, The Tudor Regime, Oxford, 1979. 
Wilson, Charles, Queen Elizabeth and the Revolt of the Netherlands, London, 1970.

Youings, Joyce, Sixteenth Century England, Harmondsworth, 1984.

\section{Other Sources}

The Oxford Dictionary of National Biography, Oxford, 2004, online ed., 2008, http://www.oxforddnb.com.

Gachard, L.P., Correspondance de Philippe II sur les Affaires des Pays-Bas, Vol.4, Brussels, 1861.

Hughes, Paul L. and James F. Larkin (eds.), Tudor Royal Proclamations: Volume II, The Later Tudors, 1553-1587, New Haven (Conn.), 1969.

Murdin, William (ed.), A Collection of State Papers, Relating to Affairs in the Reigns of King Henry VIII, King Edward VI, Queen Mary, and Queen Elizabeth, Transcribed from Original letters and Other Authentick Memorials, Left by William Cecill Lord Burghley, Vol. 2:1571-1596, London: William Bowyer, 1759.

Rymer, Thomas (ed.), Foedera, Conventiones, Literae et Cujuscunque Generis Acta Publica, Inter Reges Angliae, et Angliae et Alois Quosvis Imperatores, Reges, Pontifices, Principes, Vel Communitates, Vol.15, London: A \& J Churchill, 1713. 